Article

\title{
Application of Structural Equation Modeling (SEM) to Solve Environmental Sustainability Problems: A Comprehensive Review and Meta-Analysis
}

\author{
Abbas Mardani ${ }^{1, *}$ (D), Dalia Streimikiene ${ }^{2, *}$ (), Edmundas Kazimieras Zavadskas ${ }^{3}$ (D), \\ Fausto Cavallaro $^{4}$ (D), Mehrbakhsh Nilashi ${ }^{5}$ (D), Ahmad Jusoh ${ }^{1}$ and Habib Zare ${ }^{6}$ \\ 1 Faculty of Management, Universiti Teknologi Malaysia (UTM), Skudai Johor 81310, Malaysia; \\ ahmadj@management.utm.my \\ 2 Lithuanian Energy Institute, Breslaujos 3, LT-44403 Kaunas, Lithuania \\ 3 Department of Construction Technology and Management, Vilnius Gediminas Technical University, \\ Sauletekio al. 11, LT-10223 Vilnius, Lithuania; edmundas.zavadskas@vgtu.lt \\ 4 Department of Economics, Management, Society and Institutions (EGSI), University of Molise, \\ Via De Sanctis, 86100 Campobasso, Italy; cavallaro@unimol.it \\ 5 Faculty of Computing, Universiti Teknologi Malaysia (UTM), Skudai Johor 81310, Malaysia; \\ nilashidotnet@hotmail.com \\ 6 Faculty of Economic, Management \& Accounting, Yazd University, P.O. Box 89195-741, Yazd, Iran; \\ dr.zarehabib@gmail.com \\ * Correspondence: mabbas3@liveutm.onmicrosoft.com (A.M.); dalia@mail.lei.lt (D.S.); \\ Tel.: +60-112-734-7432 (A.M.); +370-614-03424 (D.S.)
}

Received: 6 September 2017; Accepted: 26 September 2017; Published: 10 October 2017

\begin{abstract}
Most methodological areas assume common serious reflections to certify difficult study and publication practices, and, therefore, approval in their area. Interestingly, relatively little attention has been paid to reviewing the application of Structural Equation Modeling (SEM) in environmental sustainability problems despite the growing number of publications in the past two decades. Therefore, the main objective of this study is to fill this gap by conducting a wide search in two main databases including Web of Science and Scopus to identify the studies which used SEM techniques in the period from 2005 to 2016 . A critical analysis of these articles addresses some important key issues. On the basis of our results, we present comprehensive guidelines to help researchers avoid general pitfalls in using SEM. The results of this review are important and will help researchers to better develop research models based on SEM in the area of environmental sustainability.
\end{abstract}

Keywords: environmental sustainability; structural equation modeling; comprehensive analysis; meta-analysis

\section{Introduction}

Sustainability is the biggest challenge of the 21st century because civilization has reached a point where natural resources are in rapid decline. Several previous studies have emphasized the vital role of environmental sustainability in various applications areas such as waste management [1-4], energy [5-8], sustainability performance [9-11], green product [12-15], low carbon and climate [16-18], tourism [19-22], information and communication technology [23-26], health [27,28], behavioral science [29,30], innovation [31-33], economic development [34-37], risk assessment [38-40], decision making [41-44], tourist behaviour [45-48], business practices [49-52], industrial manufacturing [53-56], agricultural [57-60], supply chain [61-64], and other applications. The environmental issues such as global warming, ozone depletion, natural resource decline, ecosystem destruction, carbon emissions have raised a concern for the causes of these problems. The conventional thoughts, principles and 
methods are currently in question and the challenge we are facing today requires radical changes and global leadership.

Sustainability can be seen as being linked to three main dimensions: the environmental, social, and economic [65-67]. However, Njoh [68] and Luthra, Kumar [24] suggest that there are now four interrelated but competing pillars that have emerged with regard to sustainability. Alongside the biophysical (environmental), the economic, and the social systems, a fourth important dimension is the political system through which power is exercised. This fourth sphere, the political or institutional dimension, functions as the referee that arbitrates in relation to the different and often incompatible claims made by the actors of the social and economic sphere [24]. How much emphasis is placed on these different dimensions or pillars may be linked to different schools of thought, discourses, rationalities or world views regarding the importance of the environment versus economic growth [69-73].

The variety of environmental perspectives on sustainability demonstrates varying emphasis on either altering the resource side or the demand side of the equation [74-83]. They reflect a spectrum from a dark green ecological perspective [84] to a light green perspective (see [85]) which draws on different epistemological assumptions and rationalities. The strong sustainability label is more closely linked to the dark green spectrum, and the light green to the weak sustainability approach. From a dark green perspective, an ecologically rational approach must have lexical priority [73], and ecological values should drive environmental decisions. It is a holistic perspective recognising the interdependence of environmental and social systems.

Collaboration between government, industry, and a strong science and technology sector with requisite research and development funding is the key to solving environmental problems [79,86-88]. While accepting the contribution that science and technology have made in creating environmental problems, they are seen as central to their resolution. Science, therefore, provides the means to better detect environmental dangers, and technological innovation enables the development of alternatives [89]. Talking about theories and models regarding environmental sustainability first raises the question of how environmental sustainability is described in these circles. Scientists doing research in the area of environmental sustainability often cite the definition of environmental sustainability based on the conferences and publications presented in the United Nations program. Kolk and Mauser [90], explore in their review a wide number of different models of environmental sustainability. According to their research, some authors see this as a continuous process towards a higher level of sustainable behavior of the company, therefore called stage models. When researchers do not assume a development over time, models are described more as a continuum of possible strategies or simply choices between equal opportunities. Probably the first publication describing strategies for environmental sustainability is the work of [91] and describes a classification of models for environmental management, based on the survey of 132 managers of US firms. Petulla [91], explores a range of possible strategies. Scholars from a wide range of disciplines and perspectives have sought to unravel the high complexities of sustainability. A mature understanding of sustainability management requires studies to adopt a multidisciplinary systemic lens capable of appreciating the interconnectivity of economic, political, social and ecological issues across temporal and spatial dimensions [92].

Several reviews on sustainability research have been conducted in recent years. However, there is still a gap in the literature regarding review papers in the field of environmental sustainability and Structural Equation Modelling (SEM).Therefore, the aim of this work is to conduct a systematic literature review of the application of SEM in examining environmental sustainability. This paper contributed to current literature by adding some new issues to environmental sustainability and SEM: first of all, the developed a classification scheme with practical considerations; second, structurally reviewed the environmental sustainability literature in a way to present a guide to the earlier research carried out on the application of SEM techniques in assessment of environmental sustainability problems and proposing several recommendations for further investigation. The third contribution of this paper classifies and reviews the selected papers based on several important criteria such as 
area, scope and sample, type of method (quantitative, qualitative or mix method), technique (partial least squares (PLS), Analysis of Moment Structures (AMOS) or other techniques), unit of analysis (individual, group and country), number of sample, respondents, related theory, measure validation (Exploratory factor analysis (EFA) or Confirmatory Factor Analysis (CFA)), data collection method (Online or offline survey), name of variables, number of hypotheses, study purpose, gap and research problem, name of author, year of publication, country of authors, and finally results and outcome. Additionally, in we provided the developed frameworks of all selected papers based on the name of author(s). We also present several recommendations and directions for future research in the area of environmental sustainability.

The remainder of this review paper is structured in the following sections. Section 2 presents the research method and procedure of this review paper. Section 3 presents classification of papers based on the application areas. Section 4 provides the breakdown of articles based on scope. Section 5 presents breakdown of articles based on type of method. Section 6 provides breakdown of articles based on technique. Section 7 provides breakdown of articles based on unit of analysis. Section 8 classified the article based related theory. Section 9 categories the article based on measure validation. Section 10 classifies of articles based on data collection method. Section 11 presents the distribution of articles by name of journals. Section 12 provides the articles by year of publication. Section 13 provides breakdowns of articles based on nationality of authors. Section 14 presents the study discussion, and finally Section 15 presents the conclusion, limitations and recommendations for future studies.

\section{Research Method}

For the research methodology in this study, we used the Preferred Reporting Items for Systematic Reviews and Meta-Analyses (PRISMA) provided by Moher, Liberati [93]. The purpose of the PRISMA statement is an evidence-based minimum set of items to help scholars for enhancing the reporting quality a wide array of systematic reviews and meta-analyses. PRISMA as a checklist is not only an instrument for quality assessment for systematic reviews; it can be very valuable for critical assessment objectives in all sections of articles such as title, abstract, introduction, method, results and discussion. PRISMA emphasizes directions in which scholars could ensure a complete and transparent and report of this type of research and presents the substantial transparency in the selection procedure of articles in a systematic review. The flow diagram of PRISMA represents the flow of information in the different stages of a systematic review. PRISMA has two main parts, including systematic reviews and meta-analyses. Systematic reviews provide objective summaries of what has been conducted on a specific research area. This is especially valuable in wide research areas, where many publications exist, each focusing on a narrow aspect of the field [94]. Systematic reviews aim to provide a full overview of research conducted in a specific area until the present date. All research procedures have to be made explicit before the actual behaviour of the review to make the process objective and replicable. Meta-analysis provides a means of mathematically integrating findings employing diverse statistical approaches to study the diversity of the articles. In this kind of synthesis, original studies that are compatible with their quality level are selected. This aspect may help and highlight different facts which individual primary studies fail to do, e.g., it may prove that results are statistically significant and relevant when small primary studies provide inconclusive and uncertain results with a large confidence interval [95]. The main goal of PRISMA is to help researchers and practitioners to complete a comprehensive and clear literature review [96].

There are some other reporting guidelines such as Consolidated Standards of Reporting Trials (CONSORT), Standards for Reporting of Diagnostic Accuracy (STARD) statement, Standards for Reporting Interventions in Clinical Trials of Acupuncture (STRICTA), Systematic Literature Reviews (SLRs), Methodi Ordinatio methodology, however; we believed that the PRISMA is comprehensive guideline for reporting the systematic review because of these benefits: determine quality of the review, allow scholars to evaluate strengths and weaknesses, permits replication of review approaches, format and structure the review through PRISMA headings. Several previous studies have been conducted 
using PRISMA in various fields to develop a comprehensive literature review [97-99]. In order to implement the PRISMA method in this study, we performed three main steps including: literature search, choosing the eligible published papers, and extraction of data and summarization [97-99].

\subsection{Literature Search}

In this step, we have chosen the Web of Science and Scopus databases to provide a comprehensive application of SEM in the assessment of environmental sustainability. The literature search was performed based on several keywords including environmental sustainability (1878 records), green and environmental supply chain (35 records), sustainability (22,021 records), green human resource management (14 records), green and environmental information technology and system (319 records), renewable and sustainable energies (288 records), green and environmental marketing (37 records), environmental operation and production (4963 records) and other related keywords such as partial least squares (195 records) and structural equation modelling (3164 records). In the first step of our search, we found 32,914 scholarly papers related to these mentioned keywords which were extracted according to our strategy search. In the next step, we searched for papers which were published and checked the duplicated papers with redundant information.

After this step, 542 papers were remaining. After removing 89 records due to duplication, we screened papers based on the titles and abstracts, and irrelevant papers were removed. In total, 279 potentially related papers remained (see Figure 1).

\subsection{Articles Eligibility}

In this step of the review, for the purpose of eligibility, we reviewed the full text of each manuscript independently (which extracted from the last step). In the last step, we carefully identified the related articles to attain a consensus. Book chapters, unpublished working papers, editorial notes, master dissertations and doctoral theses, textbooks, and non-English papers were excluded. In the end, we selected 171 articles related to the environmental sustainability topics and SEM, from 69 peer review scholarly journals, which met our inclusion criteria.

\subsection{Data Extraction and Summarisation}

In the final step of our methodology, after negotiation with other authors, some required information was collected, and finally, 171 articles were reviewed and summarised.

In Table 1, all the selected articles were classified into different classifications including, green and sustainable Supply Chain Management (SCM), Corporate Social Responsibility (CSR), renewable and sustainable energies, green and ecological innovation, green and environmental Human Resource Management (HRM), environmental information technology and systems, other green and sustainable operation management, and green and environmental marketing. Also, articles were summarised and reviewed based on the various criteria such as area, scope and sample, type of method (quantitative, qualitative or mix method), technique (PLS, AMOS or other techniques), unit of analysis (individual, group and country), number of sample, respondents, related theory, measure validation (EFA or CFA), data collection method (online or offline survey), name of variable, number of hypotheses, study purpose, gap and research problem, results and outcome, name of author, year of publication, and finally country of authors. Furthermore, we have provided and the frameworks of all selected papers based on name of author(s) (see Appendix A). We believe that reviewing, summarising and classifying the articles helped us to achieve some critical and valuable insights. Consequently, some suggestions and recommendations for the future studies were proposed. Furthermore, we believe that this review paper was performed very carefully and it presented a comprehensive source regarding the application of SEM in the assessment of environmental sustainability. It should be noted that the main difficulty of using the PRISMA method was to understand what methodologies were used from the abstract and the research methodology section of the selected articles. Thus, it was required to go through the full content of articles and take a more detailed look to evaluate the exactly used 
approach for the evaluation of environmental sustainability problem. Although a considerable amount of time was spent in the selection process, it helped us to choose the most suitable publications in conducting the review.

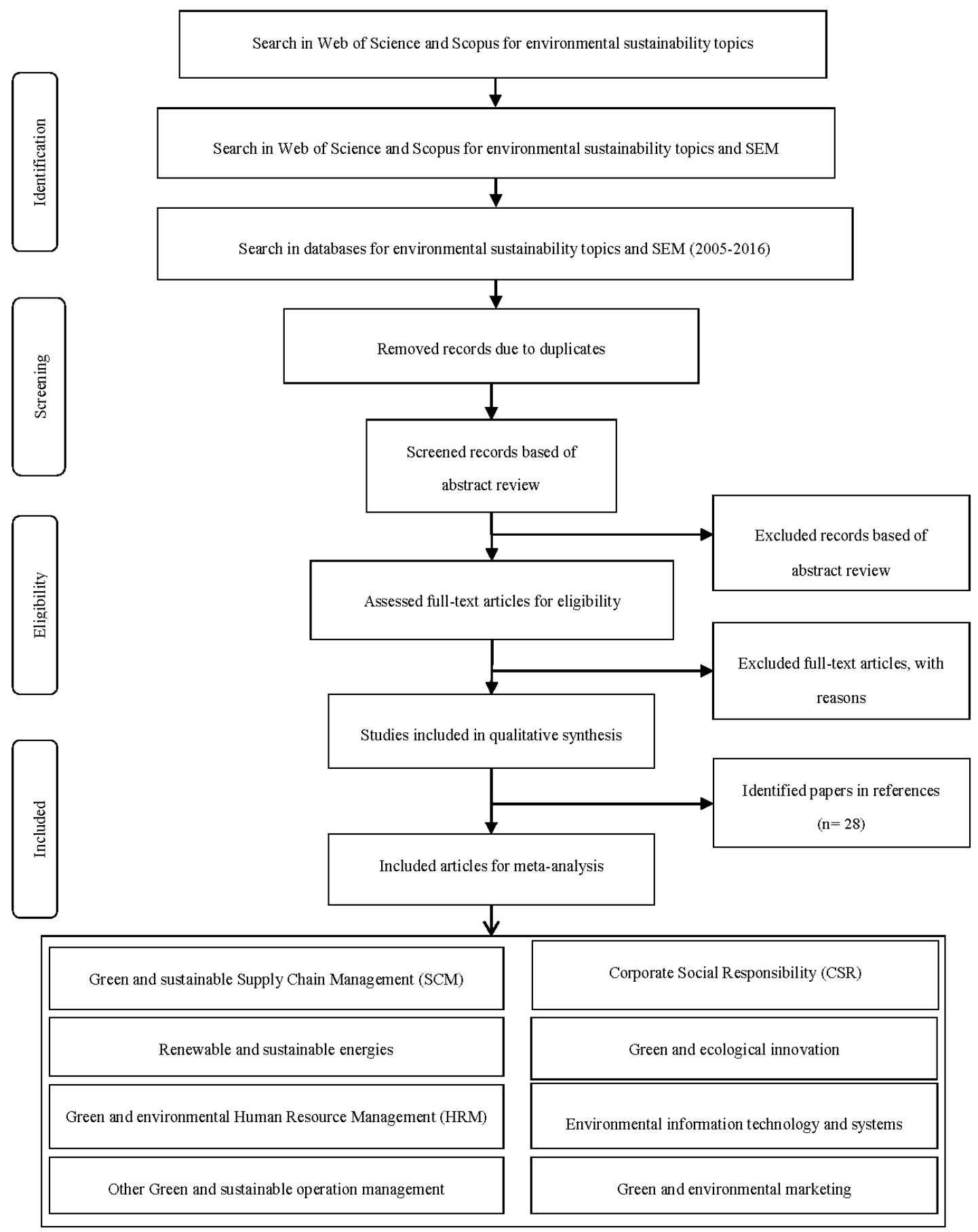

Figure 1. Study flowchart for the identification, screening, eligibility and included of articles. 
Table 1. Classification of papers based on application area.

\begin{tabular}{lcc}
\hline \multicolumn{1}{c}{ Application Areas } & Frequency & Percentage of Frequency \\
\hline Green and sustainable Supply Chain Management (SCM) & 50 & $29.24 \%$ \\
Corporate Social Responsibility (CSR) & 8 & $4.68 \%$ \\
Renewable and sustainable energies & 7 & $4.09 \%$ \\
Green and ecological innovation & 11 & $6.43 \%$ \\
Green and environmental Human Resource Management (HRM) & 32 & $18.71 \%$ \\
Environmental information technology and systems & 8 & $4.68 \%$ \\
Other Green and sustainable operation management & 28 & $16.37 \%$ \\
Green and environmental marketing & 27 & $15.79 \%$ \\
\hline \multicolumn{1}{c}{ Total } & $\mathbf{1 7 1}$ & $\mathbf{1 0 0 . 0 0 \%}$ \\
\hline
\end{tabular}

\section{Application Areas Classification}

Although categorising and combining the articles in this field is complex, for the classification task, we used the opinions of experts in the fields of sustainability.

Consequently, based on the opinions of experts, we categorised articles into six different applications areas (see Table 1). In the following section, all selected articles were summarised and reviewed based on the various criteria.

\subsection{Breakdown of Articles Based on Green and Sustainable SCM}

Environmental programmes such as green and sustainable supply chain management were an efficient programme for business organisations in handling their operations in a greener manner. Hereby, green Supply Chain Management (GSCM) performs as a significant part in affecting the whole environmental effect of any business engaged in some activities of Supply Chain (SC) and enhances sustainability performance. Many GSCM researches concentrate on the diverse topics that range from organisational research and practice in GSCM [100-104]. The lack of agreement on green SC practices is assumed to be caused from the green SC field being a new field of practice and study since the theories in this field are still identifying and underdeveloped, assessing, and choosing the vital GSCM practices are main purposes for successful GSCM implementation [105]. Several of previous studies used various techniques and methods such as SEM techniques for assessment of green and sustainable SCM. For example, Nagati and Rebolledo [106] mentioned there is lack in previous studies related to sustainable development regarding supplier's perspective. To fill this gap, this study examined the role of supplier participation in sustainable development in 210 Canadian manufacturers with several variables such as supplier's trust, preferred customer status, dynamism of the environment, participation in supplier development activities, and performance improvement. The findings of this paper showed that preferred customer status and trust were two antecedents of the supplier in sustainable development. In addition, there is a positive relationship between suppliers' participation and operational performance. Mariadoss, Chi [107] investigated consumer behavior regarding reserve GSCM perspective in U.S. manufacturing and service industries. This study found that there is a need to examine effect of different firm orientation on supply chain practices and firm purchasing in view of sustainability. The findings of this study reveal that a firm's environmental and cultural orientations affect its SPPs and SSPs, while local community orientation drives SPPs only in the large firms. Youn, Yang [108] investigated antecedents of reverse logistics metric development in 141 manufacturing firms, findings of this paper indicated that; top management support, organizational compatibility and mutual trust had a direct effect on strategic information sharing and indirect and positive effects on operational information sharing by mediate the strategic information sharing. Large and Gimenez Thomsen [109] indicated that few previous studies have paid attention to the development process of the preconditions required to modify the supplier environmental improvement approaches; therefore, this study investigated the relationship among the drivers of green SC performance and purchasing performance and environmental performance in 181 Purchasing industry. The findings of this paper showed that there is a direct influence 
between level of green collaboration and the degree of green supplier assessment. In addition, the influence of commitment on green collaboration is mediated by the purchasing department capabilities. Moreover, the results showed that there is a positive relationship between environmental performance and purchasing performance. Lee, Ooi [110] examined the relationship between GSCM and technological innovation in 133 Malaysian manufacturing companies. The results of this paper demonstrated that there was a positive and significant relationship between the internal environmental management and technological innovation, and eco-design had a positive and significant relationship with technological innovation, investment recovery had a positive and significant relationship with technological innovation, and green purchasing and cooperation with customers had a positive and significant relationship with the technological innovation.

According to Table A1 (see Appendix A), in total, 50 previous published papers [111-155] have used SEM techniques for assessment of green and sustainable SCM. This table represents significant distribution findings of green and sustainable SCM based on the author(s) names, year of publication scope and sample of study, area of study, number of sample, respondents, related theory, variables, study purpose, gap and research problem, and results and outcome.

\subsection{Breakdown of Articles Based on CSR}

The experience of implementing CSR and ethical principles in different industries can be linked to the idea that social responsibility and ethics could be used as a tool to maintain their equilibrium in the market through better communication with stakeholders [156]. Effective communication leads to better understanding of stakeholders' needs and expectations and also more opportunities. Increasing demands on CSR by various stakeholders shows that CSR could not be an exception to this rule [157]. Therefore, satisfaction of customers, as the main group of stakeholders, should be considered an intangible asset that creates real economic value for firm. Gruca and Rego [158] found that customer satisfaction creates shareholder value by increasing future cash flow growth and reducing its variability, and Fornell, Mithas [159] show that a portfolio of firms with high customer satisfaction outperforms major stock indexes. In conclusion, in a well-known definition of CSR by Carroll [160], CSR is the social responsibility of a business which includes the economic, legal, ethical, and discretionary expectations that stakeholders have of organizations at a given point in time. Stakeholders have been defined as those groups or individuals who can affect or are affected by the achievement of the organization objectives. They have been classified frequency by scholars as external and internal, voluntary and involuntary or primary and secondary targets [161]. With regard to banking industry, Pérez, Martínez [162] classify CSR dimensions to five groups as CSR oriented to customers; CSR oriented to shareholders; CSR oriented to employees; CSR oriented to the society; and a general CSR dimension concerning legal and ethical issues. After increasing importance of CSR in financial markets as a primordial part of business strategy, a considerable literature on CSR, customer expectations and outcomes in different context was generated. In recent years, several of previous scholars implemented the SEM methods in field of CSR. For instance, Reverte, Gómez-Melero [163] analyze the relationship between CSR and organizational performance by mediating impact of innovation in 133 manufacturing and non-manufacturing companies based on theory of resources and capabilities with incorporating some variables such as social dimension of CSR, economic dimension of CSR, environmental dimension of CSR, innovation, financial performance and non-financial performance. Results of this article found that there was a significant and positive relationship between CRS, innovation and organizational performance. Ağan, Kuzey [164] indicated that there is a limitation of literature regarding environmental supplier development; regarding this point, this study examined the relationship between CSR, firm performance and environmental supplier development. Some variables of this study were CSR to environment, CSR to media, CSR to employees, CSR to customers, partnership with NGOs, supplier evaluation, incentives, direct involvement, financial performance and competitive advantage. The results of this paper demonstrated that CSR is positively related to environmental supplier development and that environmental supplier 
development had the positive relationship between competitive advantage of the participating firms and financial performance. Kang, Chiang [165] investigated the relationship between CSR and business performance by using sustainability balanced scorecard in 200 hotels. To develop the framework, this study used some variables such as corporate social responsibility, financial dimensions, customer dimensions, business dimensions, learning and growth dimensions. The outcomes of this study showed that there is a significant relationship between CSR and business performance in three groups by using a balance score card. Table A2 (see Appendix A) [166-170] provided the important results of CSR papers based on the author(s) names, year of publication scope and sample of study, area of study, number of sample, respondents, related theory, variables, study purpose, gap and research problem and results and outcome.

\subsection{Breakdown of Articles Based on Renewable and Sustainable Energies}

The implementation of successful renewable energy projects that are sustainable in time, especially at community level, has been related to more open and participatory processes where views, expectations and framings from different stakeholders become integrated. Different methodologies can be found in the literature for assessment of renewable and sustainable energies. Some of them are scenario planning, which seeks to address and put limits on uncertainty, improving the response capacity to multiple futures [171]. Kowalski, Stagl [172], using a combination of scenario planning and Multi Criteria Assessment (MCA) to reduce uncertainty in energy development, where a diversity of stakeholders is included in the decision-making process, considering a broad spectrum of social, economic, environmental and technical criteria. Another approach is Participatory Technological Assessment (PTA) oriented to generate a feedback process between the technological and social criteria, as a way to predict social aspects during the technological development and increase social acceptance (Raven et al., 2009). In addition, some of the previous published papers used SEM methods to examine and analysis the data and testing the model hypotheses [173-177]. For example, Seetharaman, Sandanaraj [173] found that there is need to more focus on renewable energy market to achieve more competitive advantage, regarding to this problem. This study investigated the relationship between internal and external forces on renewable energy business in 106 energy industries with several variables such as, environmental concerns, inadequate customer relationships, technology innovation deficiencies, unstructured business process, lack of societal awareness, performance instability, regulatory policy issues, complex operation, economically unsustainable, business and technology strategies unaligned and talent shortage. The results of this paper showed that there is negative direct effect between external forces and renewable energy, positive indirect effect between internal forces and renewable energy and positive direct effect between external forces and internal forces. Chou, Kim [176] examined the differences and similarities of consumer adoption regarding the understanding of smart meters across of 220 Asian consumers in the residential buildings with involving some variable such as behavioral intention to use, attitude towards behavior, perceived expected usefulness, perceived expected ease of use, perceived risk, user expected satisfaction, social influence/norms, program contents/features, technological complexity, privacy/safety concern and energy tariff/cost. This study found that there is a need to understand consumer perception, intention and expectation regarding affect smart meter adoption behavior. The results of this paper showed that usefulness perception of consumers, risks of smart meters and ease of use influenced consumer acceptance in Taiwan, Korea and Indonesia. Privacy and safety were not the main concerns for Taiwan consumers, and in Vietnam perceived risk had no significant relationship with consumer adoption of smart meters. Böttcher and Müller [177] found there are some challenges and opportunities in manufacturing companies to measuring the reduce carbon emissions; therefore, this study investigated the determinants of measures used by 159 German auto-motive suppliers to cut carbon emissions, and their impact on performance. The results of this study showed that there was a positive impact on carbon and indirect impact on economic performance. Table A3 (see Appendix A) [178,179] shows the results of seven published papers regarding renewable and sustainable energies based on the author(s) names, year of 
publication scope and sample of study, area of study, number of sample, respondents, related theory, variables, study purpose, gap and research problem, and results and outcome.

\subsection{Breakdown of Articles Based on Green and Ecological Innovation}

The concept of green innovation focuses on software and hardware of innovation technology which has a relationship with green process and green products [180]. The authors further explained that green innovation includes technology such as green product designs, corporate environmental management, energy-saving and waste recycling. Based on the many definitions that can be found in the existing literature, in this paper, green innovation concept is given as a new idea, environmental approach, product, service or processes, which is aimed at reducing adverse environmental effects and at the same time develop product differentiation among competitors. Green innovation can be further categorised into four groups, including process innovation, marketing innovation, managerial innovation and product innovation [181,182]. Green innovation is aimed at boosting the environmental management performance to fulfil the environmental regulation requirement [180]. To reach a successful internal environmental management, both support and commitment from the top management is crucial $[183,184]$. Eltayeb, Zailani [185], further explained that support from the top management will allow for resources needed to implement new technology in addition to acquiring new knowledge more easily. Green innovation can be triggered or created by the internal and external practices in GSCM itself. Chen [186], claimed that companies need to create innovation in both internal and external environments of SCM and react to environmental issues. This was also supported by Porter [187], who indicated that companies in dynamic and competitive environment need to innovate their products or services as well as respond to the pressures from competitors, consumers, regulations and other pressures to survive. The innovation should be comprised of process and product, and environmental defense concepts into companies' product design and packaging in order to produce product differentiation [188]. In recent decades, researchers have focused on the implementing of SEM methods in field of green and ecological innovation. For example, Albort-Morant, Leal-Millán [189] examined the relationship between dynamic capabilities with green innovation performance and the mediate effect of learning capability in 112 firms from the Spanish automotive components' manufacturing sector. Some variables used in this study are: dynamic capabilities, sensing capability, learning capability, integrating capability, coordinating capability, green innovation performance, relationship learning capabilities, information sharing capability, joint sense making capability and knowledge integration capability. The results of this paper found that there were positive and significant direct and indirect effects among capabilities on green innovation performance. In addition, relationship learning capabilities can mediate the relationship between capabilities and green innovation performance. Zailani, Govindan [183] examine the green innovation adoption determinants its influence on firm performance in 153 Malaysian firms in the automotive supply chain industry. Environmental regulations, marketing demand, firms' internal initiatives, green product innovation, green process innovation, economic performance, environmental performance and social performance were variables of this study, results of this study found that, market demand, environmental regulations and firm internal initiatives had the positive relationship with green innovation initiatives, and GIIs had a positive relationship with sustainable performance. Chen, Chang [190] indicated that, there is need to emphasize on green innovation as the important tools for sustainable development in manufacturing industries. Regarding this this paper examined origins two kinds of green innovation including reactive and proactive innovations in three Taiwanese manufacturing industries based on grounded theory. Findings of this paper found that environmental culture, environmental leadership, environmental capability, the environmentalism of investors and clients and environmental regulations can generate green innovation. Table A4 (see Appendix A) [191-198] presented the results of seven published papers regarding green and ecological innovation based on the author(s) names, year of publication scope and sample of study, area of study, number of sample, respondents, related theory, variables, study purpose, gap and research problem and results and outcome. 


\subsection{Breakdown of Articles Based on Green and Environmental HRM}

In recent years scholars have devoted considerable attention to the topic of sustainability, intended as the balance between economic, social and environmental performances of the firm [199]. As a consequence, the concept of green and sustainable HRM takes the development of social, environmental and human capital capitals into account, opposing to strategic HRM that is mostly focused on achieving economic goals and maximize profitability [200,201]. Within the broad field of sustainable HRM, a growing stream of studies explores the specific relation between HRM and environmental sustainability. Indeed, developing employees' commitment and involvement towards environmental sustainability have been found to be a key factor to realize sustainable organizations [202,203]. According to Renwick, Redman [203], the integration of corporate environmental management into HRM is described as green HRM. They also stated that human resources aspects of environmental management are green HRM. Several previous scholars used the SEM methods to examine and test the relationship between hypotheses. For example, Kalamas, Cleveland [204] believed that there is a need to study the understanding of consumers' allocation regarding environmental responsibility related to external forces; in this regard, this study examines how external attributions affect pro-environmental behaviors of consumers among 263 consumers of the Canadian urban area, for developed SEM model this study used TPB by involving several variables such as corporate responsibility, government responsibility, god/higher power and natural earth-cycle. The results of this paper showed analytical ways for government and corporations to improve the pro-environmental efforts. Zhan, Tan [205] evaluated the relationship between lean and green practices and organizational performance by moderation effect of guanxi in 172 respondents from manufacturing industry, this study claimed there is a need to focus on the green and lean practice to attain sustainable development to enhance organizational performance in China context. The results of this study indicated that there was a positive relationship between green and lean practices and improving organizational performance.

Wan and Shen [206] found that there is lack of previous studies regarding urban green space which did not consider the three factors including perceived usefulness attitude, and perceived behavioural control; therefore, this paper investigated the relationships between urban green spaces attributes and urban green space use with mediating effect perceived usefulness attitude, and perceived behavioural control by using TPB theory. Perceived provision of facilities, perceived naturalness, perceived accessibility, attitude, perceived usefulness, subjective norm, perceived behavioural control, behavioural intention and behaviour were the important variables for this paper. The findings of this article found that perceived usefulness attitude, and perceived behavioural control have mediating effect in the relationship between the behavioural intention to use urban green space. In addition, urban green space does not influence behaviour indirectly with attitude factors and perceived behavioural control. Wan, Shen [207] developed a new model of recycling attitude and behaviour for finding the relationship between recycling behaviour and perceived policy effectiveness. The respondents of this study were 198 customers in four different shopping malls and two railway stations, the TPB theory was the supporting theory with some variables being incorporated such as: attitude, subjective norm, perceived behavioural control, moral norm, consequences awareness, perceived policy effectiveness, behavioural intention, direct behaviour, indirect behaviour. The results of this paper demonstrated that recycling intention is affected by moral norms, perceived behavioural control, subjective norms, awareness of consequences and perceived policy effectiveness. Furthermore, self-reported recycling behaviour and support influenced recycling intention. Table A5 (see Appendix A) [208-235] provided the finding of 32 scholarly articles regarding to green and sustainable HRM based on the author(s) names, year of publication scope and sample of study, area of study, number of sample, respondents, related theory, variables, study purpose, gap and research problem and results and outcome. 


\subsection{Breakdown of Articles Based on Environmental Information Technology and Systems}

Environmental information systems including remote sensing, computer modeling, databases and other technologies are developed around the world to address the various issues from climate change to loss of biodiversity to economic underdevelopment $[236,237]$. The implications for the human welfare, natural environment, and democratic governance are significant [238]. Environmental information systems structure what people see in the environment, and how they collaborate to deal with environmental problems [239]. They make a legal argument, scientific inquiry and consider how citizens contribute in the different governance. They are technologies designed to produce new social relationships, new truths, new forms of political decision-making and, ultimately, a renewed environment. Information system and technology help communities to find problems related to environmental issues and create informed management decisions [240]. The need for enhanced and relevant information on the environment in turn is a prerequisite to managing natural resources towards helping to achieve sustainable development [241]. Regarding these issues, a wide range of literature related to information and technology place an emphasis on environmental problems using SEM methods. For instance; Gholami, Sulaiman [242] believe that few previous papers place an emphasis on the adoption of green IS in organization for reduce the environmental influence, therefore this study examined the perception of 405 senior managers in relationship between green IS and environmental performance in service and manufacturing organizations. Institutional theory used as underpin theory for this study by focusing on some variables like attitude, coercive pressure, environmental performance, future consequences, mimetic pressure, pollution prevention, product stewardship and sustainable development. The findings of this paper show that a coercive pressure impact of attitude toward green IS does not influence mimetic pressure. In addition, there is a positive significant relationship between attitude, green IS adoption and future consequences consideration and green IS adoption had a significant relationship with environmental performance in the long term.

Ryoo and Koo [243] develop a new model based on the following variables of green practices: information system alignment, green practice-manufacturing coordination, green practices-marketing coordination, environmental performance and economic performance in 77 manufacturing firms. The findings of this paper show that there was positive relationship between green practices-IS, green practices-marketing coordination and alignment green practices-manufacturing coordination. Moreover, green practices-marketing coordination and green practices-manufacturing coordination were significant predictors for environmental performance, while green practices-IS alignment had an indirect relationship with environmental performance by incorporating green practices-marketing coordination and green practices-manufacturing coordination. Akman and Mishra [244] examine the role of green information technology in IT professionals in private and public sectors in 182 public and private sectors. Technology Acceptance Model (TAM) was used for this study with the following variables: perceived ease-of-use, subjective norms, perceived usefulness, attitude toward, and actual system usage level of awareness. The findings of this paper showed that: there was diversity among establishments from public- and private-sectors in the impact of the PEU on PU and on the ATU, and TAM is important for private-sector establishments excluding the relations between the PEU and ATU and PEU and PU. Table A6 (see Appendix A) [245-249] represented the results of eight published articles regarding environmental information technology and systems based on the author(s) names, year of publication scope and sample of study, area of study, number of sample, respondents, related theory, variables, study purpose, gap and research problem and results and outcome.

\subsection{Breakdown of Articles Based on Other Green and Sustainable Operation Management}

The overall success of being able to assess the sustainability of a company's operation management is highly dependent on which set of indicators are used [250]. However, what to measure to truly measure sustainability is difficult to define according to [251]. Indicators can provide a path for the business in it its progress towards sustainability. It can also provide a link between green and sustainability performance and business success. Several frameworks have been developed to guide 
businesses in their quest for selecting appropriate indicators [252-254]. Sustainability is an initiative increasingly essential to the core business model of many companies [255]. There are many diverse perspectives on sustainability in operation management such as green product development [256], green procurement and green supplier development [257], green shipping management capability [258], green and environmental issues [259] and corporate sustainability [260] and other perspectives. Some companies consider it to be the burden of more government regulations, new compliance requirements and higher manufacturing costs. However, industry leading companies recognize that sustainability can actually be a business driver for next-generation products, more efficient operations and increased profitability. Previous and current literature has used various techniques and methods to examine and analyze sustainable and green operation management areas such as SEM. SEM methods have been used in various previously published papers; for example, Campón-Cerro, Hernández-Mogollón [261] investigated the role of loyalty for sustainable advantage and identify the loyalty factors for understanding destination loyalty in rural tourism destinations. Expectancy disconfirmation theory was used as the underpinning theory with some additional factors such as image, quality, value, attribute satisfaction, overall satisfaction and loyalty. The findings of this paper showed that quality, destination attribute satisfaction and image were the direct antecedents for loyalty in the rural tourism destination. Blohmke, Kemp [262] believed that there is a need to analyze the interaction among environmental policy determinant; therefore, this study evaluated the determinants of environmental policy on international environmental governance and national environmental policy in private sectors data sets of 47 countries. For this paper, environmental policy theory was used by incorporating some variables such as green advocacy, awareness, governance capacity, international environmental governance and national environmental policy. Findings of this study demonstrated that government capacity and green industry advocacy have a positive impact on environmental policy.

Lai and Cheng [263] investigate the influence of undergraduate students regarding green marketing practices and their attitude toward the environment, their environmental responsibility and the seriousness of their perceived environmental problem. The results of this paper found that there is a strong relationship between perceived environmental responsibility and green products purchase willingness, there is no relationship between perceived seriousness of environmental problems and undergraduate students' green product purchase willingness and there are significant relationships between students' willingness to purchase green products and their green purchase behavior. Luzzini, Brandon-Jones [264] found there is lack of focus in previous studies in relation of sustainability commitments on development of collaborative capabilities for supply functions and purchasing on sustainability performance; therefore, this study examined the relationship between sustainability commitment, collaborative capabilities and performance. The finding of this paper showed that there is a link between sustainability commitment and collaborative capabilities, cost performance and social and environmental performance. Jabbour, Jugend [256] investigated the relationship between GPD practices on firm performance such as market, environmental and operational aspects with some factors such as environmental practices, operational performance, human/organizational aspects, green performance, technological aspects and market performance. The results of this paper found that GP practices affected firm performance and technical aspects. Table A7 (see Appendix A) mentioned the analysis of 28 studies [265-283] regarding green and sustainable operation management based on the author(s) names, year of publication scope and sample of study, area of study, number of sample, respondents, related theory, variables, study purpose, gap and research problem and results and outcome.

\subsection{Breakdown of Articles Based on Green and Environmental Marketing}

Green marketing is on the rise and a rather new area acknowledged for research. There is no one universal definition of green marketing and the definition generally varies according to the researcher's viewpoint. The most recent definition of green marketing has completely progressed in terms of its 
variables. It states that green marketing involves the marketing strategies used to achieve a firm's financial as well as strategic goals while reducing its negative impact on the environment [284]. Kumar and Anand [285] and Ottman [286] have characterized green marketing as an integration of ecological concerns into marketing aspects including production, distribution and logistics, promotion and packaging along with marketing communications. On the other hand, Prakash [287] defines green marketing as an environmentally considered strategy that consists of disclosing information to consumers at different levels like industry, firm and product level. Green marketing is associated with identifying the consumer needs and satisfying those needs in a valuable and sustainable manner [288]. It can be inferred from various literature that green marketing basically bridges the communication between environmentally conscious firms and consumers, in turn strengthening their relationship. Empirical researches have recognised that issues regarding sustainability, awareness about environmental issues and green brands are becoming a focal point in developed and developing nations, with added consciousness from the government and population in general. Various other studies have been pursued on green marketing and the strategies used for communication in order to influence the consumer purchase behaviour. It is observed that a correlation exists between consumers' environmental beliefs and their confidence in the performance of green products [289]. Empirical researches have used several methods and approaches like SEM. For example, De Giovanni and Esposito Vinzi [290] analyzed the relationship between environmental training and environmental management maturity in 178 manufacturing companies. This study found there is a lack of work in previous studies regarding empirical study related to external and internal environmental management and firms performance. The results of this paper showed that the European Union's Emissions Trading System (ETS) should focus on internal environmental management, internal environmental practices to improve the economic performance, and supplier collaboration which can slightly affect firms' performance.

Martínez-Martínez, Cegarra-Navarro [291] investigated the role of the SECL model mediated between the environmental knowledge and organizational performance with socialisation, externalisation, combination, internalisation and business performance. The finding of this paper showed that time is an important factor for implementation of the SECI model in organizations operating. Jabbour, Jabbour [292] believe that there are no studies related to environmental management, operational performance human resource and lean manufacturing. Therefore, this study examined the impact of environmental management on operational performance by incorporating human resources and lean manufacturing. Human resources, operational performance, environmental management and lean manufacturing were the main factors for this study. The results of this paper demonstrated that human resources had a significant relationship with environmental management, lean manufacturing and influence on environmental management compared to operational performance and there was a positive relationship between environmental management and operational performance. Xia, Chen [293] investigated the relationship among green technology selection, firm performance and circumstance pressure by using ecological theory. The findings of this paper demonstrated that there is a significant relationship between certain task-oriented circumstances and macro circumstances and green technology selection. The authors of [294] investigated the role of core Environmental Management System (EMS) in sustainable competitive advantage in manufacturing firms. The theory of production competency, RBV theory and contingency theory have been used for this study. The findings of this paper showed that environmentally responsible suppliers, cross-functional cooperation and top management team's strategic perception were the important factors for successful implementation of EMSs. Yu and Ramanathan [295] believe that there is a need for more study in relationships among stakeholder pressures, internal green management, green product/process design and environmental performance; thus, this study explores stakeholder pressures, internal green management, green product/process design and environmental performance by implementing the stakeholder theory in 167 Manufacturing firms. The main factors of this study were stakeholder pressures, internal green management, green product/process design 
and environmental performance. The findings of this study showed that stakeholder pressures had a positive and significant influence on internal green management and there was a significant and positive relationship between internal green management and green product/process design. Also, two green operations practices had a positive and significant relationship with environmental performance. Table A8 (see Appendix A) represented the findings of 27 studies [296-316] regarding green and environmental marketing based on the author(s) names, year of publication scope and sample of the study, area of study, number of sample, respondents, related theory, variables, study purpose, gap and research problem and results and outcome.

\section{Breakdown of Articles Based on Scope}

SEM has become prevalent within a variety of disciplines, particularly management research, for analyzing the cause-and-effect relations between latent constructs [317]. The term SEM refers to a family of covariance-based statistical methods. SEM is a very general statistical modeling technique, which is widely used in the various fields such as sustainability. It can be viewed as a combination of factor analysis and regression or path analysis. The interest in SEM is often on theoretical constructs, which are represented by the latent factors [318]. The relationships between the theoretical constructs are represented by regression or path coefficients between the factors. The structural equation model implies a structure for the covariances between the observed variables, which provides the alternative name covariance structure modeling [318]. SEM method has been used in various studies around the world in several different industries like tourism and the hospitality industry service and manufacturing industries, transportation industry, firms, universities and other industries and sectors.

In Figure 2 we provided the percentages of each industry which is incorporated in this study and implemented the SEM method. According to the results of this paper, manufacturing firms or industry had the highest percentage with 53 percent, the second rank was related to service firms with 17 percent, and tourism and hospitality had the third rank with 11 percent among other industries and sectors. The information related to the percentage of all scopes is provided in Figure 2.

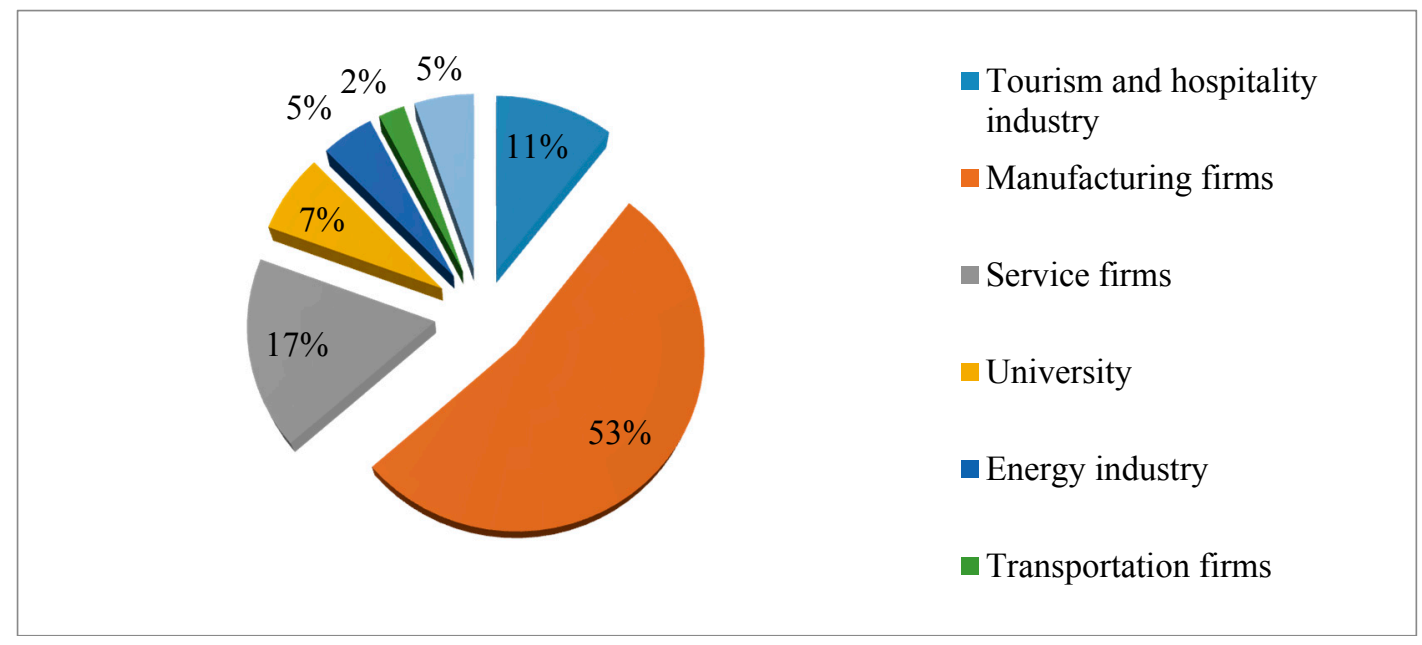

Figure 2. Breakdown of articles based on scope.

\section{Breakdown of Articles Based on Type of Method}

Types of research methods can be classified into several categories according to the nature and purpose of the study and other attributes. Types of research methods can be broadly divided into two categories, quantitative and qualitative. Quantitative research describes, infers, and resolves problems using numbers. Emphasis is placed on the collection of numerical data, the summary of those data and the drawing of inferences from the data [319]. Qualitative research, on the other hand, is based on words, feelings, emotions, sounds and other non-numerical and unquantifiable elements. 
It has been noted that "information is considered qualitative in nature if it cannot be analysed by means of mathematical techniques. This characteristic may also mean that an incident does not take place often enough to allow reliable data to be collected" [320]. In this study, to show the type of method, we divided the selected studies into three types of methods, including: quantitative, qualitative and a mix of quantitative and qualitative methods.

The frequency of each method is provided in Figure 3. According to Figure 3, from 171 reviewed papers, 168 papers use the quantitative method and no paper uses the qualitative method. However, the mix method was used in three papers. In our review paper, we focused on the application of SEM in previous studies; therefore, for this reason the number of studies which used the qualitative method was zero. The breakdown of articles based on type of method is presented in Figure 4 .

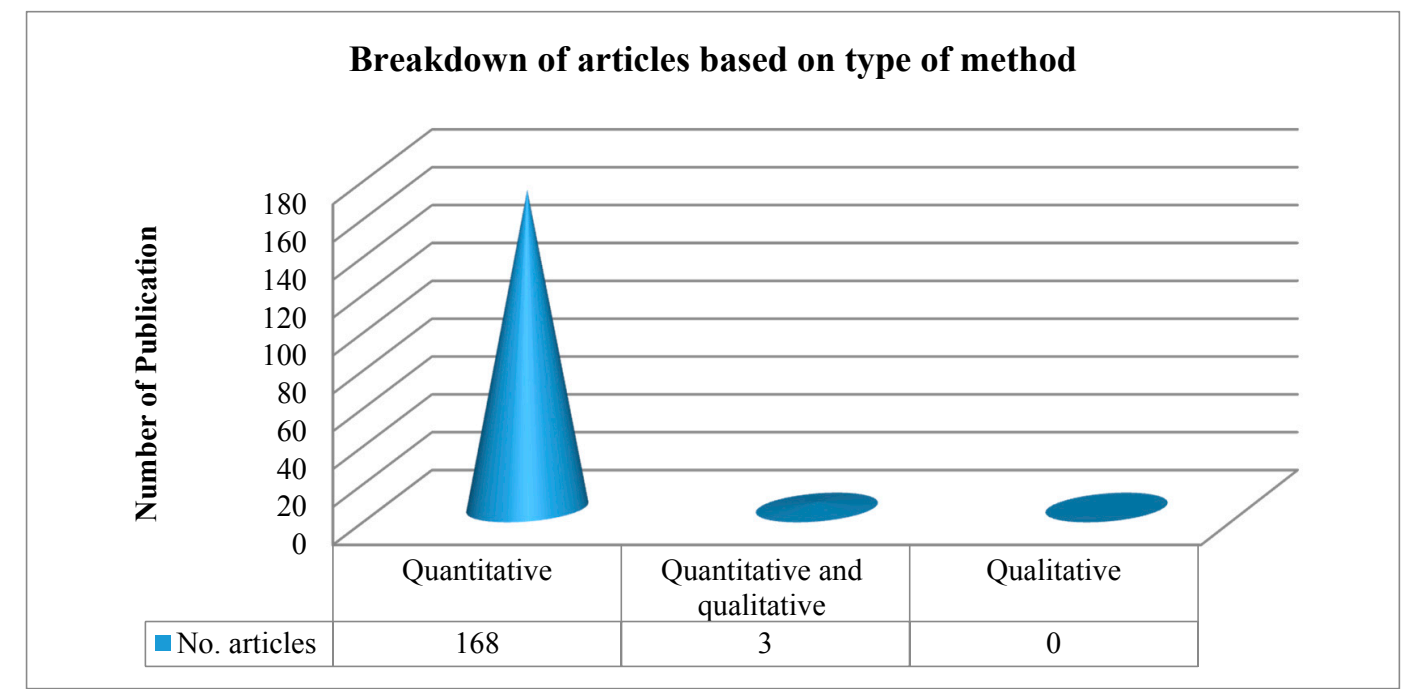

Figure 3. Breakdown of articles based on type of method.

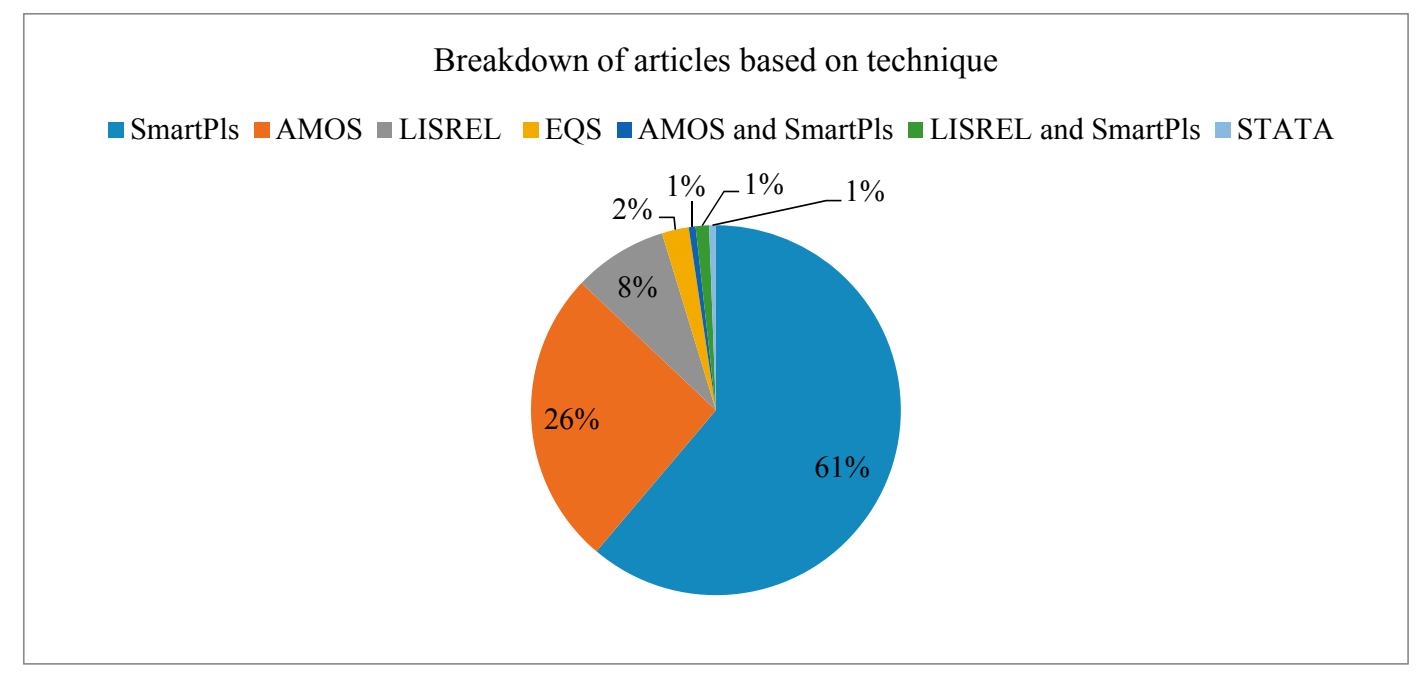

Figure 4. Breakdown of articles based on technique.

\section{Breakdown of Articles Based on Technique}

The technique for the analysis of selected studies was another important category for this review paper. In this section, we divided the reviewed papers based on SEM techniques such as AMOS, SmartPLS, LISREL, STATA, EQS, integration of AMOS and SmartPLS and integration of SmartPLS and LISREL. 
According to the findings, we found that most of the published papers have used SmartPLS with 105 papers. AMOS has the second rank among 171 selected papers with 26 percent. The information regarding the percentages of techniques is provided in Figure 4.

\section{Breakdown of Articles Based on Unit of Analysis}

One of the most important ideas in this research review was the unit of analysis. The unit of analysis is the major entity that researchers have analyzed in environmental sustainability fields. Typical units of analysis include individuals, countries, groups, social organizations and social artifacts. In our review paper, we divided the unit of analysis into three main levels including individual level, organizational level and country level.

According to the findings of this study, we found that individual level had the first rank among 171 papers with 78 percent and organizational level was the second type of unit of analysis with 21 percent. Information regarding all parts is shown in Figure 5. The comparison of the results presented by Figure 5 is interesting as we can see that organizations played an important role in environmental sustainability developments as the majority of the research was conducted at the organization level. Generally, this indicates that organization level has been more important for environmental sustainability developments in relation to the individual and country levels.

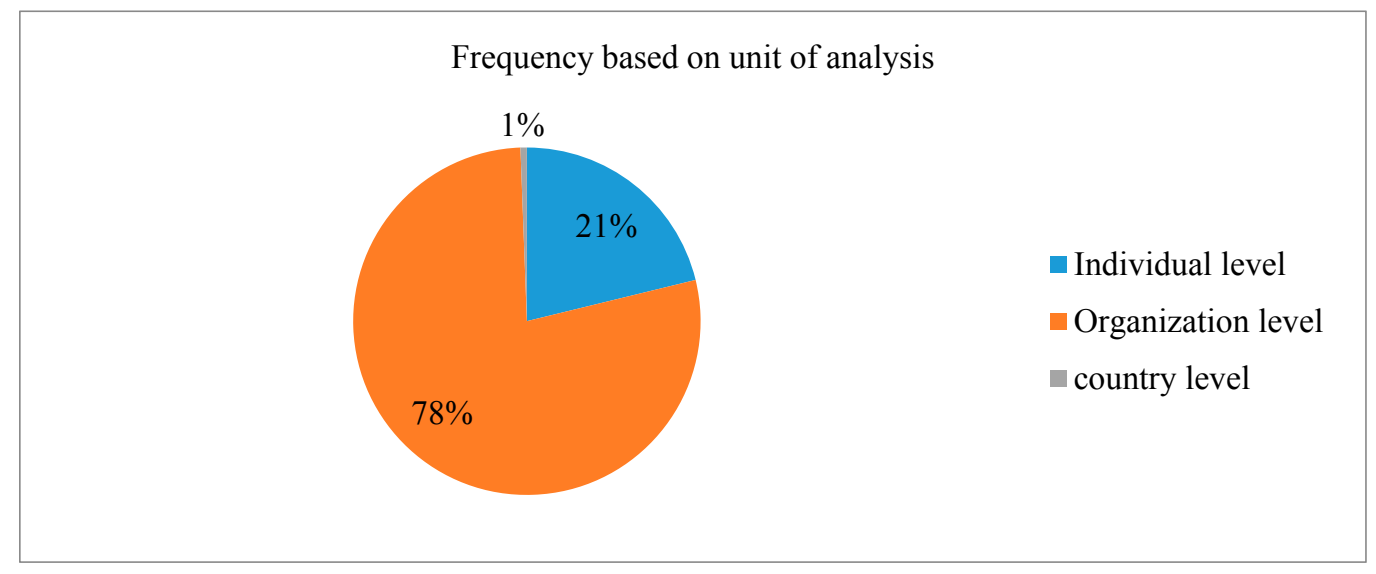

Figure 5. Breakdown of articles based on unit of analysis.

\section{Breakdown of Articles Based on Related Theory}

Categorizing the selected papers based on theory was another interesting issue for this review paper. According to our findings, various theories have been implemented in environmental sustainability fields. In total, 40 theories contributed to the field of environmental sustainability. Some important theories were: Resource-Based View (RBV), stakeholder theory, institutional theory (INT), Theory of Planned Behavior (TPB), transaction cost theory, Transaction Cost Theory (TCT), Resource Theory (RDT), social capital theory, Theory of Reasoned Action (TRA), contingency theory, ecological modernization theory, technology acceptance model, organizational theory, expectancy theory, theory of dynamic capabilities, agency theory, motivation theory, Schwartz's theory, absorptive capacity theory and social network theory. However, based on our review, in some of selected articles, we could not find related theories; therefore, we categorized these articles with a no or none-theory label.

According to our findings, in fields of environmental sustainability, RBV theory and stakeholder theory had the first and second rank with 26 and 24 records respectively. Figure 6 represented the information of all theories. The comparison of the results presented by Figure 6 is interesting as we can see that RBV, which has been found to be a management device used to assess the available amount of a business' strategic assets, is often used in conducting research on environmental sustainability. 
This indicates that the resource-based method is seen as an effective and efficient application for all useful resources that will help environmental sustainability developers in determining their competitive advantage. In addition, although, as discussed earlier, several empirical studies have been conducted for environmental sustainability development by investigating the critical success factors incorporated to the research theories, the results presented in this study can be seen as comprehensive because most theories along with their factors are reported in this study for the first time in the literature.

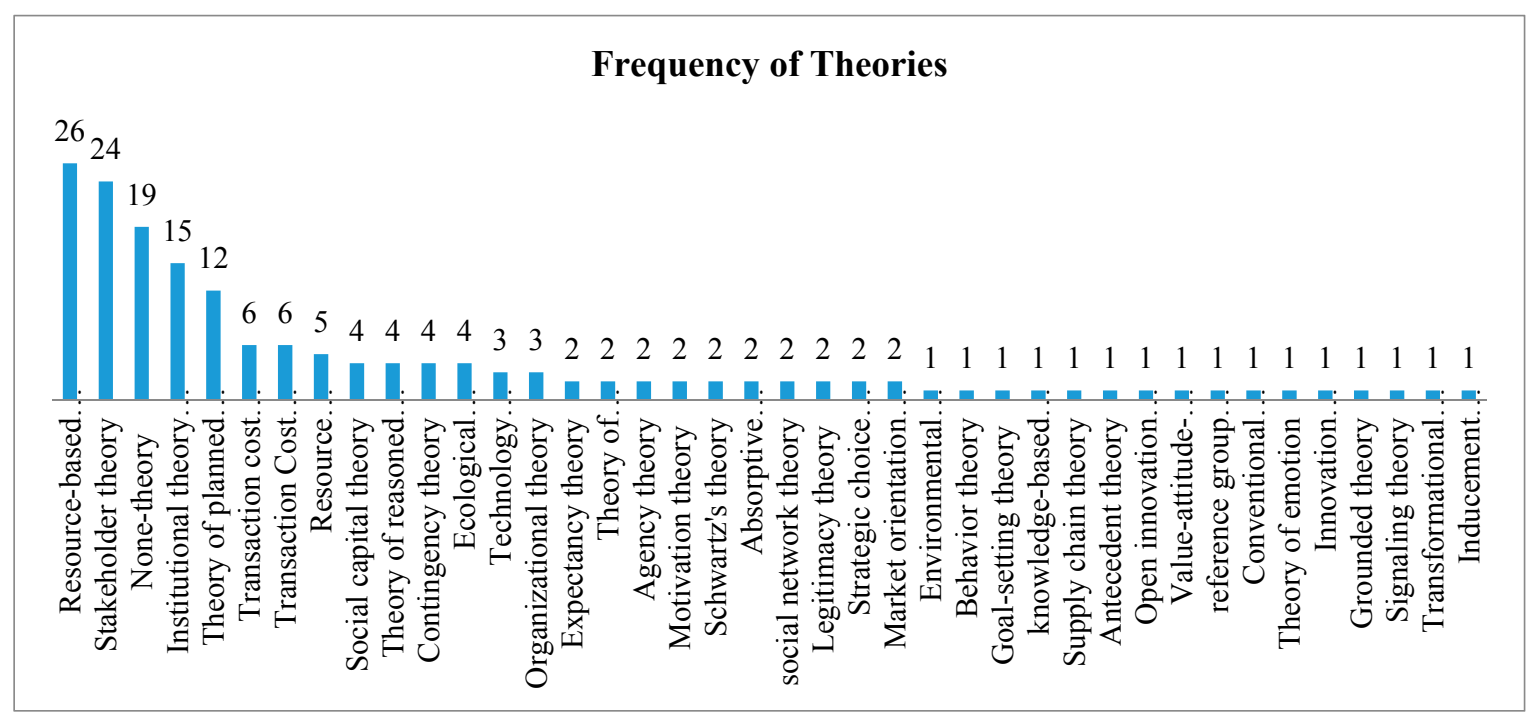

Figure 6. Breakdown of articles based on related theories.

\section{Breakdown of Articles Based on Measure Validation}

Figure 7 provided the frequency of papers based on the measurement validation. Measurement instruments are widely used for research and policy decision making purposes in many professional disciplines. The quality of the data and the quality of the decisions and inferences made based on the scores from the measurement instruments are therefore not inconsequential. Validity and validation are the most fundamental issues in the development, evaluation, and use of measurement instruments. Validity refers to the quality of the inferences, claims, or decisions drawn from the scores of an instrument and validation is the process in which we gather and evaluate the evidence to support the appropriateness, meaningfulness, and usefulness of the decisions and inferences that can be made from instrument scores [321]. In this paper, we divided the measurement validity based on two important types: Exploratory Factor Analysis (EFA) and Confirmatory Factor Analysis (CFA).

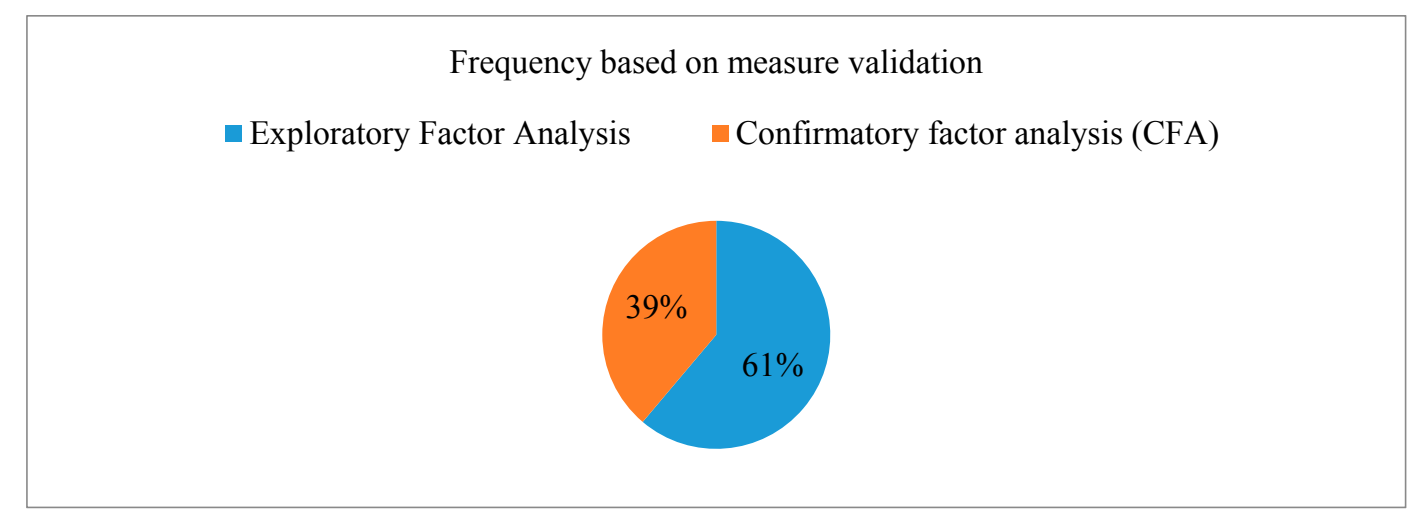

Figure 7. Breakdown of articles based on measure validation. 
According to the findings of this section, EFA has been used in the selected papers with 105 records and CFA with 65 records. Figure 7 represents the frequency of measure validation use in the selected articles.

\section{Breakdown of Articles Based on Data Collection Method}

Data Collection is an important aspect of any type of research study. Inaccurate data collection can impact upon the results of a study and ultimately lead to invalid results. There are several ways to undertake data collection. In this study, we classified the papers based on two types including an online survey and offline survey.

According to the outcome of this section, we found that 60 percent of the reviewed papers used an online survey to collect the data for their model evaluation. The frequency of articles based on the data collection method is shown in Figure 8.

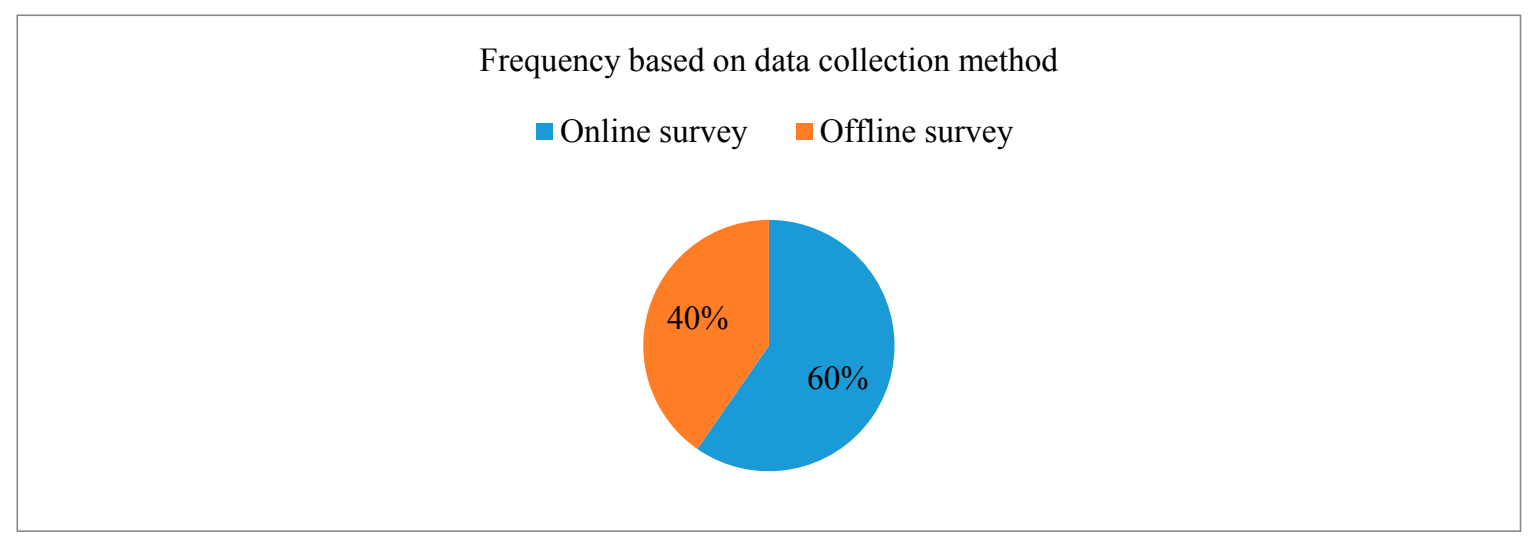

Figure 8. Breakdown of articles based on data collection method.

\section{Breakdown of Articles by Journals}

Table 2 presents the results of analyzing articles based on the title of the journals. The articles related to environmental sustainability have been chosen from 69 different international scholarly journals indexed in the Web of Science and Scopus databases. Selected published articles, along with an extensive diversity of journals that focus on environmental sustainability, validate the willingness of different scholarly journals to publish in this field. By far the highest ranking journal is the Journal of Cleaner Production with 32 articles, followed by the International Journal of Production Research with eight papers. Additionally, in other rankings, the Journal of Operations and Production Management and Industrial Management and Data Systems had the third highest rank with seven publications, followed by the journal of Transportation Research Part E: Logistics and Transportation Review with six articles.

Table 2. Breakdown of articles by journals.

\begin{tabular}{lcc}
\hline \multicolumn{1}{c}{ Title of Journal } & No. Paper & Percentage (\%) \\
\hline Journal of Cleaner Production & 32 & $18.71 \%$ \\
International Journal of Production Research & 8 & $4.68 \%$ \\
Journal of Operations \& Production Management & 7 & $4.09 \%$ \\
Industrial Management \& Data Systems & 7 & $4.09 \%$ \\
Transportation Research Part E: Logistics and Transportation Review & 6 & $3.51 \%$ \\
Industrial Marketing Management & 5 & $2.92 \%$ \\
Journal of Business Research & 5 & $2.92 \%$ \\
International Journal of Production Economics & 5 & $2.92 \%$ \\
Journal of Purchasing and Supply Management & 5 & $2.92 \%$ \\
Supply Chain Management: An International Journal & 5 & $2.92 \%$ \\
\hline
\end{tabular}


Table 2. Breakdown of articles by journals.

\begin{tabular}{|c|c|c|}
\hline Title of Journal & No. Paper & Percentage $(\%)$ \\
\hline Tourism Management & 4 & $2.34 \%$ \\
\hline Journal of Business Ethics & 4 & $2.34 \%$ \\
\hline Resources, Conservation and Recycling & 3 & $1.75 \%$ \\
\hline International Journal of Hospitality Management & 3 & $1.75 \%$ \\
\hline Management Decision & 3 & $1.75 \%$ \\
\hline Technological Forecasting and Social Change & 2 & $1.17 \%$ \\
\hline Journal of Environmental Psychology & 2 & $1.17 \%$ \\
\hline Renewable and Sustainable Energy Reviews & 2 & $1.17 \%$ \\
\hline International Journal of Information Management & 2 & $1.17 \%$ \\
\hline Journal of Environmental Management & 2 & $1.17 \%$ \\
\hline Computers in Human Behavior & 2 & $1.17 \%$ \\
\hline International Business Review & 2 & $1.17 \%$ \\
\hline Management Research Review & 2 & $1.17 \%$ \\
\hline The International Journal of Logistics Management & 2 & $1.17 \%$ \\
\hline International Journal of Contemporary Hospitality Management & 2 & $1.17 \%$ \\
\hline European Journal of Innovation Management & 2 & $1.17 \%$ \\
\hline Production Planning \& Control & 2 & $1.17 \%$ \\
\hline Business Strategy and the Environment & 2 & $1.17 \%$ \\
\hline The International Journal of Human Resource Management & 2 & $1.17 \%$ \\
\hline Maritime Policy \& Management & 2 & $1.17 \%$ \\
\hline Journal of Destination Marketing \& Management & 1 & $0.58 \%$ \\
\hline Environmental Research & 1 & $0.58 \%$ \\
\hline Transportation Research Part D: Transport and Environment & 1 & $0.58 \%$ \\
\hline Decision Support Systems & 1 & $0.58 \%$ \\
\hline Habitat International & 1 & $0.58 \%$ \\
\hline Energy Policy & 1 & $0.58 \%$ \\
\hline The Social Science Journal & 1 & $0.58 \%$ \\
\hline Information \& Management & 1 & $0.58 \%$ \\
\hline Expert Systems with Applications & 1 & $0.58 \%$ \\
\hline Asia Pacific Management Review & 1 & $0.58 \%$ \\
\hline Management Accounting Research & 1 & $0.58 \%$ \\
\hline Journal of Sustainable Development \& World Ecology & 1 & $0.58 \%$ \\
\hline Management Research: Journal of the Iberoamerican Academy of Management & 1 & $0.58 \%$ \\
\hline IEEE Transactions on Engineering Management & 1 & $0.58 \%$ \\
\hline Facilities & 1 & $0.58 \%$ \\
\hline The International Journal of Advanced Manufacturing Technology & 1 & $0.58 \%$ \\
\hline Clean Technologies and Environmental Policy & 1 & $0.58 \%$ \\
\hline Information Systems Frontiers & 1 & $0.58 \%$ \\
\hline Information Technology and Management & 1 & $0.58 \%$ \\
\hline Quality \& Quantity & 1 & $0.58 \%$ \\
\hline Applied Research in Quality of Life & 1 & $0.58 \%$ \\
\hline Review of Managerial Science & 1 & $0.58 \%$ \\
\hline Logistics Research & 1 & $0.58 \%$ \\
\hline The Service Industries Journal & 1 & $0.58 \%$ \\
\hline Engineering Management Journal & 1 & $0.58 \%$ \\
\hline Global Business Review & 1 & $0.58 \%$ \\
\hline International Journal of Logistics Research and Applications & 1 & $0.58 \%$ \\
\hline Total Quality Management \& Business Excellence & 1 & $0.58 \%$ \\
\hline Journal of Environmental Planning and Management & 1 & $0.58 \%$ \\
\hline International Journal of Physical Distribution \& Logistics Management & 1 & $0.58 \%$ \\
\hline International Journal of Productivity and Performance Management & 1 & $0.58 \%$ \\
\hline International Marketing Review & 1 & $0.58 \%$ \\
\hline Marketing Intelligence \& Planning & 1 & $0.58 \%$ \\
\hline Online Information Review & 1 & $0.58 \%$ \\
\hline Journal of Computer Information Systems & 1 & $0.58 \%$ \\
\hline Social Responsibility Journal & 1 & $0.58 \%$ \\
\hline International Journal of Consumer Studies & 1 & $0.58 \%$ \\
\hline Technological and Economic Development of Economy & 1 & $0.58 \%$ \\
\hline Anatolia & 1 & $0.58 \%$ \\
\hline Total & 171 & $100.00 \%$ \\
\hline
\end{tabular}

Hence, based on the results of this section, we can conclude that these selected journals can be considered as the main journals on environmental sustainability. Table 2 presents the list of journals where such work has been published. 


\section{Breakdown of Articles by Year of Publication}

In recent decades, application of SEM in environmental sustainability has increased dramatically in the literature. A historical growth of environmental sustainability has existed for many years. A frequency analysis of the 171 articles based on the articles published for different years is shown in Figure 9. During 2010-2012, the articles published on the application of SEM in environmental sustainability were at a steady rate with zero, three and 21 articles. An uptrend in output was observed from the year 2012 until 2016. Figure 9 presents relevant information based on the frequency of breakdown by the year of publication.

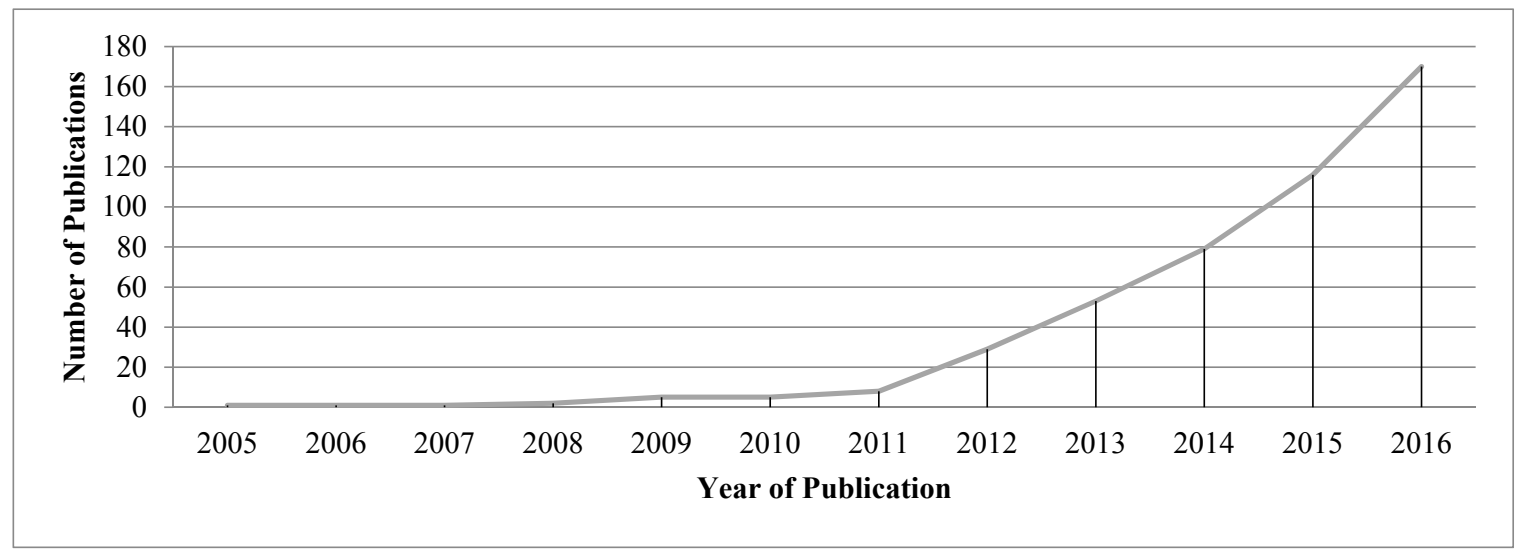

Figure 9. Breakdown of articles by year of publication.

Accordingly, it can be indicated that nowadays there are many researchers in the field of environmental sustainability and it can be predicted that in coming years these numbers will increase.

\section{Breakdown of Articles Based on Nationality of Authors}

This review paper attempted to show the difference among countries related to environmental sustainability. Two kinds of principles were used for identifying the characteristics in selected articles, including the information gained directly from the papers or the nationality of the first author. Figure 10 shows that authors from 31 nationalities and countries used SEM in environmental sustainability.

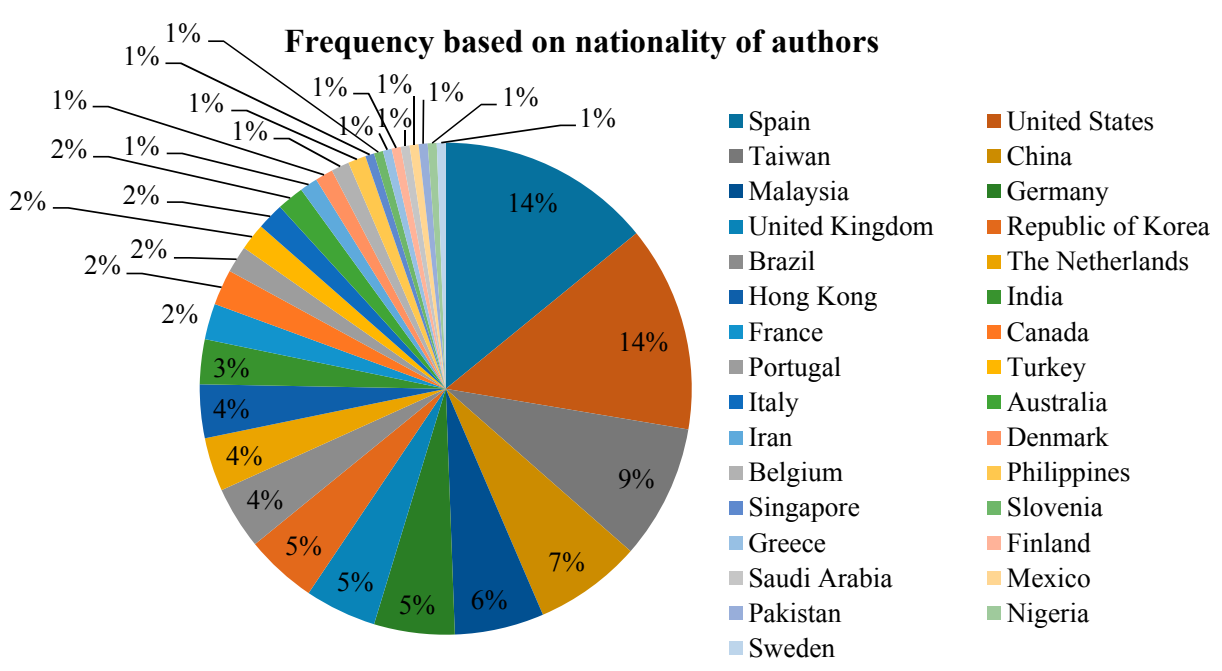

Figure 10. Breakdown of articles based on nationality of authors. 
Most of the published papers were from Spain with 25 publications followed by United States, Taiwan and China with 23, 15 and 12 publications, respectively. Figure 10 shows the breakdown of articles based on the nationality of authors. The comparison of the results presented by Figure 10 is interesting as we can see that some developing countries such as China and Malaysia are relatively good at conducting research on environmental sustainability. However, we can find some research in the literature that shows research into environmental sustainability being conducted separately for some countries. However, such results for the majority of developing and developed countries are reported in this study for the first time in the literature.

\section{Discussion}

There are some challenges regarding the application of SEM in environmental sustainability problem areas that could be interesting for discussion and future studies. The interesting result of this review paper was the outcome regarding the data collection method, which, in this review, we divided into two main groups: online survey and offline survey. According to the outcome of this section, we found that 60 percent of reviewed papers have used an online survey for data collection. These results show that, nowadays, use of the internet by managers, students, tourist, employees, consumers, customer, organizations, hotels, companies, universities, firms and other people and sectors has increased dramatically. The last decade has seen a tremendous increase in computer-mediated communication and internet use. Scholars in several disciplines use the internet as a successful field for conducting survey research. As the cost of computer software and hardware continues to decrease and the acceptance of the internet increases, more sectors of society are using the internet for information and communication. Another exacting result was regarding the number of countries that participated in this review paper. The results of this section showed that, in total, 31 nationalities and countries were focused on the sustainability environmental fields. Among these countries, there are some developing countries, and this shows that in recent years these countries have also attempted to focus more on environmental sustainability issues.

In addition, in our review paper, the results were interesting regarding the scope of studies. In the section of scope, we classified the sectors and organizations based on hospitality industry service and manufacturing industries, transportation industry, firms, and universities. According to the results, although manufacturing industries had the first rank among other sectors and industries with 53 percent, the service industry had only 17 percent. Based on this result, we can indicate that, nowadays, manufacturing industries have more focus on environmental sustainability compared to other sectors. Furthermore, in this review paper, there are some challenges regarding underpinning theories that selected studies have implemented to develop study models and frameworks. According to the results of this paper, in total, 40 theories have contributed to the field of environmental sustainability. Some of the important theories were: RBV, stakeholder theory, INT, TPB, transaction cost theory, TCT, RDT, social capital theory, TRA, contingency theory, ecological modernization theory, technology acceptance model, organizational theory, expectancy theory, theory of dynamic capabilities, agency theory, motivation theory, Schwartz's theory, absorptive capacity theory and social network theory. According to our findings, the theory of RBV contributed more to the fields of environmental sustainability more than other theories, with 26 records. The second theory which contributed in this field was stakeholder theory with 24 records. There was a challenge regarding using the TPB theory in the fields of environmental sustainability. By extending the TPB, as seen in [322], which claims that users' intentions are a very powerful predictor of actual behavior, a number of researchers have investigated a consumer's intention in order to predict the actual purchases [323,324]. The TPB is one of the most commonly used models in explaining and predicting the individual behavioral intention [323]. TPB is an attitude-intention-behavior model, which posits that an individual's behavior is determined by perceived behavioral control and intention. Intention, in turn, is determined by attitude, subjective norm, and perceived behavioral control [323]. Although in this paper we attempted to present a comprehensive review paper regarding environmental sustainability, nonetheless, only a few 
previous papers have used TPB. According to this result, we can indicate that, in recent years, behavioral intention was not an important issue in the field of environmental sustainability.

We also found that there are some challenges in the literature regarding environmental sustainability fields, for example, in the field of sustainable rural tourism destinations. Future studies require us to continue to extend our understanding of the role of loyalty in the area of rural tourism destinations and sustainable ways to take the benefits of socioeconomic of tourism in rural environments. Furthermore, further research would allow us to examine the relationships between perceived sustainability and behavioral constructs or other different perceptions in the area of tourism experience, like overall image, attitude towards the destination, loyalty and behavioral intention. In the field of sustainable and green SCM, some studies focused on the improvement of supplier operational performance only; therefore, it is necessary to explore the influence of supplier sustainable development on the performance of suppliers' marketing and financial situation. In addition, further studies need to advance the understanding of the behavioral implications and assessment of green consumer perceptions in reverse green SCM. Moreover, further research might focus on the strategic sustainability orientation to better explain the sustainability behaviors which are implemented in a firm. Future studies can also emphasize the various types of green SCM that could be worth considering by conducting the research to examine differences by size, industry or age of company to develop the inter-organizational relationships. In the area of environmental orientation, further research would explore the role of green SCM on the impact of some management-based practice mediation mechanisms, such as marketing-based downward stream management practice and performance relationship. In the area of reverse logistics and supply chain, future research is required to emphasize some antecedents and outcomes such as financial performance agility and trading partner relationship satisfaction. However, in the field of green and sustainable SCM there are some other topics which would be interesting for further research to consider.

Finally, compared to the research found in the literature, our study contributed to the literature by analyzing the papers conducted by a statistical technique, SEM, which is a powerful analytical tool for methodological evaluation of models by multivariate analysis. In addition, in our study, a complete collection of research papers conducted empirically for environmental sustainability developments were analyzed and the results were reported. The findings can be interesting as the theories and their factors for environmental sustainability developments were comprehensively investigated for developed and developing countries in this study for the first time in the literature. In addition, compared to the empirical qualitative and quantitative research found in the literature, this study analysed the papers conducted on environmental sustainability on several methodological aspects which can give researchers insights into their data analysis and model development from new perspectives.

\section{Conclusions}

This review paper presented a comprehensive overview of recent SEM methods in the various applications areas of environmental sustainability. In total, 171 papers were selected for systematic review and meta-analysis in the period 2005-2016 from popular international journals accessible in the Web of Science and Scopus databases. We carefully selected and reviewed 171 studies about environmental sustainability and SEM based on the title, abstract, introduction, research methods and conclusions. These selected papers were categorised into eight application areas. Also, all papers were classified based on the name of the author, year of publication, country of authors, area, scope and sample, type of method (quantitative, qualitative or mix method), technique (PLS, AMOS or other techniques), unit of analysis (individual, group and country), number of sample, respondents, related theory, measure validation (EFA and CFA), data collection method (Online or offline survey), name of variables, number of hypotheses, study purpose, gap and research problem, and finally results and outcome. In addition, in the Appendix A we provided the developed frameworks in the selected papers based on the name of author(s). 
An understanding of some issues regarding the application of SEM in environmental sustainability is gained from this review article. The vast majority of reviewed articles were published between 2012 and 2016. In total, the papers were classified into eight areas including green and sustainable SCM, CSR, renewable and sustainable energies; green and ecological innovation, green and environmental HRM; environmental information technology and systems, other green and sustainable operation management, and green and environmental marketing. Green and sustainable SCM was the most important application area with 50 papers. Furthermore, 69 international peer review journals were considered in the current review paper. The Journal of Cleaner Production had the first rank among the considered journals regarding publishing papers related to environmental sustainability and SEM.

Finally, various limitations inherent to this review study give rise to directions for future studies. The articles published at the beginning of 2017 (if any) have not been included in the present paper because of the limited reporting time. However, we attempted to use those published articles in other sections of our review paper, such as related works and introduction sections. Nonetheless, this present review can be developed to include the future studies. Another limitation is that the data was collected from journals, while the examined documents did not include textbooks, doctoral and master's theses and unpublished papers regarding application of SEM in environmental sustainability problems. Although we attempted to provide a comprehensive review based on current and old literature, nevertheless, as a recommendation for future studies, the data can be collected from these sources, and the obtained results can be compared with the data obtained and reported in this study. Another limitation of this review was that all of the papers were extracted from journals written in English. Hence, scientific journals in other languages were not included in the review. However, the researchers believe that this paper comprehensively reviewed most of the papers published in international journals. In this paper, we reviewed 171 papers which recently studied environmental sustainability but attempted to include a comprehensive list of papers in other sections. We carefully selected and summarised the available papers of several publishers in the Web of Science and Scopus databases. However, some relevant outlets remained beyond the scope of the current study. Therefore, future researchers may attempt to review the papers which are not considered in the current review. Another limitation of the survey is that, although the paper presents various journals and conference publications that recently studied the application of SEM in environmental sustainability, it does not include any aspects of this topic discussed in the published books.

Acknowledgments: The authors would like to thank the Research Management Center (RMC) at Universiti Teknologi Malaysia (UTM) and Ministry of Higher Education (Malaysia) for supporting and funding this research under the Fundamental Research Grant Scheme (FRGS) (Vote No. FRGS/1/2016/TK03/UTM/02/14).

Author Contributions: All authors contributed equally to this work.

Conflicts of Interest: The authors declare no conflict of interest. 


\section{Appendix A}

Table A1. Breakdown of articles based on green and sustainable SCM.

\begin{tabular}{|c|c|c|c|c|c|c|c|c|}
\hline Author(s) Year & Scope and Sample & Sample Size & Respondents & Related Theory & Variables & Study Purpose & Gap and Research Problem & Results and Outcome \\
\hline $\begin{array}{c}\text { Nagati and } \\
\text { Rebolledo [106] }\end{array}$ & $\begin{array}{c}\text { Canadian } \\
\text { manufacturers }\end{array}$ & 201 & $\begin{array}{l}\text { Senior executives or } \\
\text { production managers }\end{array}$ & Expectancy theory & $\begin{array}{l}\text { Supplier's trust, Preferred customer } \\
\text { status, Dynamism of the environment, } \\
\text { Participation in supplier development } \\
\text { activities, Performance improvement }\end{array}$ & $\begin{array}{l}\text { Examine role of supplier } \\
\text { participation in } \\
\text { sustainable development. }\end{array}$ & $\begin{array}{l}\text { There is lack of previous } \\
\text { studies related to sustainable } \\
\text { development regarding } \\
\text { supplier's perspective. }\end{array}$ & $\begin{array}{l}\text { Findings of this paper showed that preferred } \\
\text { customer status and trust were } \\
\text { two antecedents of supplier in sustainable } \\
\text { development. In addition, there is a positive } \\
\text { relationship between suppliers' participation } \\
\text { and operational performance. }\end{array}$ \\
\hline Couto et al. [111] & $\begin{array}{l}\text { Flash Barometer } \\
\text { from } 28 \\
\text { European countries }\end{array}$ & 26,573 & Consumers & $\begin{array}{l}\text { Transaction cost } \\
\text { economics; social } \\
\text { network theory; } \\
\text { stakeholder theory; } \\
\text { and institutional } \\
\text { theory }\end{array}$ & $\begin{array}{l}\text { Buying Decision, Product information, } \\
\text { Perceived value and consumer } \\
\text { willingness to pay or buy. }\end{array}$ & $\begin{array}{l}\text { Investigated consumer } \\
\text { behavior regarding reserve } \\
\text { GSCM perspective. }\end{array}$ & $\begin{array}{l}\text { Need to focus on Behavior of } \\
\text { consumers regarding to pay or } \\
\text { buy green product. }\end{array}$ & $\begin{array}{l}\text { Results of this study found that there is a } \\
\text { strong relationship between buying decision } \\
\text { process and perceived value and positive } \\
\text { relationship willingness to pay and product } \\
\text { information and no relationship between } \\
\text { perceived value and product information, } \\
\text { willingness to pay and perceived value and } \\
\text { willingness to pay and the buying } \\
\text { decision process. }\end{array}$ \\
\hline $\begin{array}{l}\text { Mariadoss } \\
\text { et al. [107] }\end{array}$ & $\begin{array}{l}\text { U.S. manufacturing } \\
\text { and } \\
\text { service industries }\end{array}$ & 149 managers & Managers & Stakeholder theory & $\begin{array}{l}\text { sustainable purchasing practices, } \\
\text { sustainable supply practices } \\
\text { environmental orientation, cultural } \\
\text { preservation orientation, societal } \\
\text { orientation, and local community } \\
\text { orientation }\end{array}$ & $\begin{array}{l}\text { Examined the relationship } \\
\text { between firm's orientation } \\
\text { and sustainable SCM. }\end{array}$ & $\begin{array}{l}\text { Need to examine effect of } \\
\text { different firm orientation on } \\
\text { supply chain practices and } \\
\text { firm purchasing in view of } \\
\text { sustainability. }\end{array}$ & $\begin{array}{l}\text { Our findings reveal that a firm's } \\
\text { environmental and cultural orientations affect } \\
\text { its SPPs and SSPS, while local community } \\
\text { orientation drives SPPs only in large firms. }\end{array}$ \\
\hline $\begin{array}{l}\text { Cheng and } \\
\text { Sheu [112] }\end{array}$ & $\begin{array}{c}\text { Green } \\
\text { manufacturing firms }\end{array}$ & $\begin{array}{c}451 \\
\text { manufacturing }\end{array}$ & $\begin{array}{l}\text { senior management } \\
\text { team }\end{array}$ & Behavior theory & $\begin{array}{l}\text { Relational benefits, Relational } \\
\text { proclivity, Connectedness, } \\
\text { Opportunistic behavior, Dysfunctional } \\
\text { conflict and Quality of strategy. }\end{array}$ & $\begin{array}{l}\text { Proposed a novel study } \\
\text { model to investigate the } \\
\text { relationship of factors } \\
\text { influencing the quality of } \\
\text { strategies developed and } \\
\text { inter-organizational } \\
\text { relationships in the green SC. }\end{array}$ & $\begin{array}{l}\text { Need to highlight the role of } \\
\text { value-based partnership in the } \\
\text { relational and economic views. }\end{array}$ & $\begin{array}{l}\text { Results of this study found that there is a } \\
\text { positive relationship between strategy quality } \\
\text { and relationship orientation. }\end{array}$ \\
\hline Chan et al. [113] & $\begin{array}{c}\text { Foreign } \\
\text { invested enterprises }\end{array}$ & $\begin{array}{l}194 \text { foreign } \\
\text { invested } \\
\text { enterprises } \\
\text { operating }\end{array}$ & $\begin{array}{l}30 \text { senior executives } \\
\text { working }\end{array}$ & $\begin{array}{l}\text { Organizational } \\
\text { learning theory and } \\
\text { institutional theory }\end{array}$ & $\begin{array}{l}\text { Internal environmental orientation, } \\
\text { External environmental orientation, } \\
\text { Green Purchase, Customer } \\
\text { Cooperation, Investment Recovery, } \\
\text { Competitive Intensity Corporate } \\
\text { Performance and Social Desirability } \\
\text { Bias. }\end{array}$ & $\begin{array}{l}\text { Examined the relationship } \\
\text { among environmental } \\
\text { orientation, GSCM activities } \\
\text { and corporate performance. }\end{array}$ & $\begin{array}{l}\text { Few previous studies have } \\
\text { focused on the relationship } \\
\text { among environmental } \\
\text { orientation, GSCM activities } \\
\text { and corporate performance, } \\
\text { despite the potential for } \\
\text { employing GSCM to improve } \\
\text { marketing practices and } \\
\text { ultimately enhance firm } \\
\text { competitiveness such } \\
\text { employment. }\end{array}$ & $\begin{array}{l}\text { Outcomes of this paper showed that there is } \\
\text { positive relationship between green purchase, } \\
\text { customer cooperation and external and } \\
\text { internal environmental orientations, and a } \\
\text { positive relationship with corporate } \\
\text { performance, also there is a positive } \\
\text { relationship between customer cooperation } \\
\text { and corporate performance. }\end{array}$ \\
\hline Hazen et al. [114] & $\begin{array}{l}\text { United States } \\
\text { Department of } \\
\text { Defense } \\
\text { supply chain }\end{array}$ & 60 & Senior management & $\begin{array}{l}\text { Goal-setting theory } \\
\text { and the } \\
\text { knowledge-based } \\
\text { view }\end{array}$ & $\begin{array}{l}\text { Cost effectiveness, Processing } \\
\text { effectiveness, IS capability, Goals } \\
\text { and metrics. }\end{array}$ & $\begin{array}{l}\text { Investigated antecedents of } \\
\text { reverse logistics metric } \\
\text { development. }\end{array}$ & $\begin{array}{l}\text { There is hardly any literature } \\
\text { regarding antecedents and } \\
\text { outcomes of reverse logistics } \\
\text { metric development. } \\
\end{array}$ & $\begin{array}{l}\text { Results of this article found that specified } \\
\text { goals and information systems were the most } \\
\text { important antecedents of reverse logistics } \\
\text { metric development. }\end{array}$ \\
\hline Youn et al. [108] & $\begin{array}{l}\text { Manufacturing } \\
\text { firms }\end{array}$ & 141 & Top management & None & $\begin{array}{l}\text { Information sharing, mutual trust, top } \\
\text { management support, organiziztional } \\
\text { compatibility, strategic operational } \\
\text { information sharing, environmental } \\
\text { and business performance }\end{array}$ & $\begin{array}{l}\text { Examine the relationship } \\
\text { between strategic supply } \\
\text { chain partnership (SSCP) } \\
\text { and environmental supply } \\
\text { chain management (ESCM). }\end{array}$ & $\begin{array}{l}\text { Regarding the global } \\
\text { environmental requirements, } \\
\text { need to explore and integrate } \\
\text { ESCM and SCCP for attain the } \\
\text { sustainable competitive } \\
\text { advantage. }\end{array}$ & $\begin{array}{l}\text { Findings of this paper indicated that top } \\
\text { management support, organizational } \\
\text { compatibility and mutual trust had the direct } \\
\text { effect on strategic information sharing and } \\
\text { indirect and positive effects on operational } \\
\text { information sharing by mediate the strategic } \\
\text { information sharing. }\end{array}$ \\
\hline
\end{tabular}


Table A1. Breakdown of articles based on green and sustainable SCM.

\begin{tabular}{|c|c|c|c|c|c|c|c|c|}
\hline Author(s) Year & Scope and Sample & Sample Size & Respondents & Related Theory & Variables & Study Purpose & Gap and Research Problem & Results and Outcome \\
\hline $\begin{array}{l}\text { Large and Gimenez } \\
\text { Thomsen [109] }\end{array}$ & Purchasing industry & 181 & Customers & Antecedent theory & $\begin{array}{l}\text { Strategic level of purchasing, } \\
\text { Environmental commitment, } \\
\text { Purchasing's cuvironmental } \\
\text { capabilities, Green supplier assessment, } \\
\text { Green collaboration with suppliers, } \\
\text { Environmental performance } \\
\text { improvement and Purchasing } \\
\text { performance. }\end{array}$ & $\begin{array}{l}\text { Investigated the relationship } \\
\text { among the drivers of green } \\
\text { SC performance and } \\
\text { purchasing performance and } \\
\text { environmental performance. }\end{array}$ & $\begin{array}{l}\text { Few previous studies have } \\
\text { paid attention to the } \\
\text { development process of the } \\
\text { preconditions required to } \\
\text { modify the supplier } \\
\text { environmental improvement } \\
\text { approaches. }\end{array}$ & $\begin{array}{l}\text { Findings of this paper showed that there is a } \\
\text { direct influence between level of green } \\
\text { collaboration and the degree of green } \\
\text { supplier assessment. In addition, the } \\
\text { influence of commitment on green } \\
\text { collaboration is mediated by the purchasing } \\
\text { department capabilities. Moreover, there is a } \\
\text { positive relationship between environmental } \\
\text { performance and purchasing performance. }\end{array}$ \\
\hline $\begin{array}{c}\text { Xu and } \\
\text { Gursoy [115] }\end{array}$ & Hospitality & 499 & Consumers & $\begin{array}{l}\text { Means-end theory } \\
\text { and social theory }\end{array}$ & $\begin{array}{l}\text { Customer satisfaction, customer } \\
\text { loyalty, customer willingness to pay, } \\
\text { environmental and economic and } \\
\text { social dimensions. }\end{array}$ & $\begin{array}{l}\text { The main purpose of this } \\
\text { study to examine the impact } \\
\text { of SSCM on customers' } \\
\text { behaviors and attitudes. }\end{array}$ & $\begin{array}{l}\text { There is a need to consider to } \\
\text { three dimensions of } \\
\text { sustainability including } \\
\text { economic, social and } \\
\text { environmental in all section of } \\
\text { hospitality industry such as } \\
\text { collaboration with } \\
\text { stockholders involve } \\
\text { supply chain. }\end{array}$ & $\begin{array}{l}\text { Findings of this paper showed that there is } \\
\text { positive relationship between customer } \\
\text { satisfaction, customer loyalty, willingness to } \\
\text { pay a premium and environmental and } \\
\text { economic criteria, there was negative } \\
\text { relationship between social criteria and } \\
\text { willingness to pay a premium, and a positive } \\
\text { relationship with customer satisfaction. }\end{array}$ \\
\hline $\begin{array}{l}\text { De Giovanni and } \\
\text { Esposito Vinzi [116] }\end{array}$ & Italian firms & 138 & Executives & None & $\begin{array}{l}\text { Internal environmental management, } \\
\text { Internal environmental management, } \\
\text { Environmental performance and } \\
\text { economic performance. }\end{array}$ & $\begin{array}{l}\text { The main aim of this paper is } \\
\text { to investigate the } \\
\text { relationship between EM } \\
\text { and performance in GSCM. }\end{array}$ & $\begin{array}{l}\text { Need to use performance as } \\
\text { the formative variable in green } \\
\text { supply chain management. }\end{array}$ & $\begin{array}{l}\text { Results of this paper found that internal EM } \\
\text { increased the performance compared with } \\
\text { external EM, although it did not increase } \\
\text { economic performance. }\end{array}$ \\
\hline $\begin{array}{l}\text { Esfahbodi } \\
\text { et al. [117] }\end{array}$ & $\begin{array}{l}128 \text { manufacturing } \\
\text { firms ( } 72 \text { in China } \\
\text { and } 56 \text { in Iran) }\end{array}$ & 128 & Managers & $\begin{array}{l}\text { Resource } \\
\text { dependence theory } \\
\text { (RDT) }\end{array}$ & $\begin{array}{l}\text { Sustainable procurement, Sustainable } \\
\text { distribution, Sustainable design, } \\
\text { Investment recovery, Environmental } \\
\text { performance, Cost performance }\end{array}$ & $\begin{array}{l}\text { Investigated and compared } \\
\text { the effect of sustainable SCM } \\
\text { adoption on cost and } \\
\text { environmental performance. }\end{array}$ & $\begin{array}{l}\text { There is a need for more } \\
\text { investigations to understand } \\
\text { SSCM in developing countries. }\end{array}$ & $\begin{array}{l}\text { Findings of this paper found that, there were } \\
\text { some similarities between Iran and China; } \\
\text { also results found that SSCM adoption } \\
\text { practices in higher levels of the } \\
\text { environmental performance but does not } \\
\text { necessarily lead to improved cost } \\
\text { performance. }\end{array}$ \\
\hline Lee et al. [110] & $\begin{array}{l}\text { Malaysian } \\
\text { manufacturing }\end{array}$ & 133 & managerial & $\begin{array}{l}\text { Resource-based } \\
\text { view (RBV) }\end{array}$ & $\begin{array}{l}\text { Internal environmental management, } \\
\text { Eco-design, Investment recovery, } \\
\text { Green purchasing, Cooperation with } \\
\text { customers and technological } \\
\text { innovation }\end{array}$ & $\begin{array}{l}\text { The main goal of this paper } \\
\text { is to examine the } \\
\text { relationship between GSCM } \\
\text { and technological } \\
\text { innovation. }\end{array}$ & $\begin{array}{l}\text { Lack of attention on } \\
\text { technological innovation in } \\
\text { previous studies in } \\
\text { relationship between GSCM } \\
\text { and performance. }\end{array}$ & $\begin{array}{l}\text { The results of this paper demonstrated that } \\
\text { there was positive and significant relationship } \\
\text { between internal environmental management } \\
\text { and technological innovation, and eco-design } \\
\text { had a positive and significant relationship } \\
\text { with technological innovation. Investment } \\
\text { recovery had a positive and significant } \\
\text { relationship with technological innovation, } \\
\text { and green purchasing and cooperation with } \\
\text { customers had a positive and significant } \\
\text { relationship with technological innovation. }\end{array}$ \\
\hline $\begin{array}{l}\text { Akamp and } \\
\text { Müller [118] }\end{array}$ & 137 German firms & 137 & $\begin{array}{l}\text { Purchasing } \\
\text { managers and } \\
\text { managing directors } \\
\text { of firms }\end{array}$ & $\begin{array}{l}\text { Transaction cost } \\
\text { theory }\end{array}$ & $\begin{array}{l}\text { Supplier selection and evaluation, } \\
\text { Supplier monitoring, Supplier } \\
\text { development and Supplier integration }\end{array}$ & $\begin{array}{l}\text { The main aim of this paper is } \\
\text { to investigate the measure of } \\
\text { supplier management can } \\
\text { improve buyer satisfaction } \\
\text { and supplier performance. }\end{array}$ & $\begin{array}{l}\text { There are various challenges in } \\
\text { developing countries related to } \\
\text { sourcing activities and } \\
\text { environmental and social } \\
\text { problems. }\end{array}$ & $\begin{array}{l}\text { Findings of this paper showed that supplier } \\
\text { development, supplier selection and } \\
\text { evaluation, and supplier integration can } \\
\text { improve supplier performance. }\end{array}$ \\
\hline Kuei et al. [119] & $\begin{array}{l}\text { Focal, downstream, } \\
\text { and upstream firms }\end{array}$ & 167 & Senior executives & None & $\begin{array}{l}\text { Relative advantage, compatibility, } \\
\text { complexity, organizational support, } \\
\text { quality of human resources, customer } \\
\text { pressure, regulatory pressure, } \\
\text { government support, environmental } \\
\text { uncertainty, focal firm-green practice, } \\
\text { process efficiency, product quality, } \\
\text { economic performance, green } \\
\text { performance and environmental } \\
\text { management capabilities. }\end{array}$ & $\begin{array}{l}\text { The main aim of this paper is } \\
\text { to identify the critical factors } \\
\text { which impact on the } \\
\text { adoption of GCM practices. }\end{array}$ & $\begin{array}{l}\text { There is need to present the } \\
\text { comprehensive framework for } \\
\text { help to successful } \\
\text { implementation of green SCM. }\end{array}$ & $\begin{array}{l}\text { Results of this study found that the external } \\
\text { environmental factors were the most } \\
\text { important factors in adopting of green } \\
\text { practices, these factors were environmental } \\
\text { uncertainty, regulatory pressures, customer } \\
\text { pressures and government support. }\end{array}$ \\
\hline
\end{tabular}


Table A1. Breakdown of articles based on green and sustainable SCM.

\begin{tabular}{|c|c|c|c|c|c|c|c|c|}
\hline Author(s) Year & Scope and Sample & Sample Size & Respondents & Related Theory & Variables & Study Purpose & Gap and Research Problem & Results and Outcome \\
\hline Sancha et al. [120] & $\begin{array}{c}\text { Spanish } \\
\text { manfacturing firms }\end{array}$ & 120 & Manager & $\begin{array}{c}\text { Transaction Cost } \\
\text { Theory (TCT) and } \\
\text { the Resource Based } \\
\text { View (RBV) }\end{array}$ & $\begin{array}{l}\text { Assessment, Collaboration, Supplier's } \\
\text { Social Performance, benefit of of } \\
\text { Employee Well-Being, benefit of Social } \\
\text { Reputation. }\end{array}$ & $\begin{array}{l}\text { The main aim of this paper is } \\
\text { to extend the current } \\
\text { sustainability literature to } \\
\text { suppliers and focus on } \\
\text { suppliers' assessment and } \\
\text { suppliers' collaboration. }\end{array}$ & $\begin{array}{l}\text { There is a lack in previous } \\
\text { papers of focus on the social } \\
\text { dimension of sustainability. }\end{array}$ & $\begin{array}{l}\text { Findings of this paper showed that } \\
\text { evaluating suppliers improved the buying } \\
\text { firm's social performance and collaborating } \\
\text { with suppliers improves the suppliers' social } \\
\text { performance. }\end{array}$ \\
\hline Woo et al. [121] & $\begin{array}{l}\text { Construction } \\
\text { suppliers }\end{array}$ & 103 & Managers & Social capital theory & $\begin{array}{l}\text { Information sharing, environmental } \\
\text { collaboration, green alignment, green } \\
\text { cost reduction, corporate } \\
\text { competitiveness. }\end{array}$ & $\begin{array}{l}\text { The main purpose of this } \\
\text { paper is to investigate the } \\
\text { relationship between } \\
\text { communication capabilities } \\
\text { for GSCM and green cost } \\
\text { reduction, external green } \\
\text { integration and corporate } \\
\text { competitiveness. }\end{array}$ & $\begin{array}{l}\text { Need to focus on the increase } \\
\text { of satisfaction the needs of } \\
\text { buyers and customers related } \\
\text { to environmental capabilities } \\
\text { in the construction sector. }\end{array}$ & $\begin{array}{l}\text { Results of this paper found that there was a } \\
\text { positive relationship between suppliers' } \\
\text { communication capability and green cost } \\
\text { reduction, green alignment between } \\
\text { suppliers and buyers enhanced the supplier } \\
\text { competitiveness and environmental } \\
\text { collaboration mediated the relationship } \\
\text { between information sharing and } \\
\text { performance. }\end{array}$ \\
\hline Laari et al. [122] & $\begin{array}{c}\text { Finnish } \\
\text { manufacturing firms }\end{array}$ & 119 & Managers & None & $\begin{array}{l}\text { Environmental collaboration with } \\
\text { customers, environmental monitoring } \\
\text { by customers, environmental } \\
\text { performance, financial performance, } \\
\text { internal GSCM, environmental } \\
\text { collaboration with suppliers and } \\
\text { environmental monitoring of suppliers. }\end{array}$ & $\begin{array}{l}\text { The main aim of this study is } \\
\text { to find the indirect and } \\
\text { direct relationships between } \\
\text { customer-driven GSCM } \\
\text { practices financial and } \\
\text { environmental performance. }\end{array}$ & $\begin{array}{l}\text { Need to focus on the literature } \\
\text { related to customer-driven } \\
\text { GSCM practices and } \\
\text { performance. }\end{array}$ & $\begin{array}{l}\text { Results of this study indicated that, there was } \\
\text { the positive relationshipip between } \\
\text { environmental performance, internal GSCM } \\
\text { practices and internal GSCM practices, and } \\
\text { also there was the positive relationship } \\
\text { between environmental collaboration and } \\
\text { financial performance. }\end{array}$ \\
\hline Teixeira et al. [123] & $\begin{array}{l}\text { Manufacturing } \\
\text { firms with ISO } 14001 \\
\text { certification }\end{array}$ & 95 & Managers & $\begin{array}{l}\text { Ecological } \\
\text { modernization } \\
\text { theory }\end{array}$ & $\begin{array}{l}\text { Green Training, Green Supply Chain } \\
\text { Management, green purchasing and } \\
\text { collaborating with customers. }\end{array}$ & $\begin{array}{l}\text { The main aim of this study is } \\
\text { to analyze the relationship } \\
\text { among green training, } \\
\text { collaborating with customer } \\
\text { and green purchasing. }\end{array}$ & $\begin{array}{l}\text { Need to emphasis on green } \\
\text { training factor for } \\
\text { implementation of GSCM. }\end{array}$ & $\begin{array}{l}\text { The results of this paper found that, green } \\
\text { training had the positive impact with GSCM } \\
\text { practices such as cooperation with customers } \\
\text { and green purchasing. }\end{array}$ \\
\hline $\begin{array}{l}\text { Kumar and } \\
\text { Rahman [124] }\end{array}$ & $\begin{array}{c}\text { Manufacturing } \\
\text { industry }\end{array}$ & 157 & $\begin{array}{c}\text { Middle and } \\
\text { top-level managers }\end{array}$ & $\begin{array}{l}\text { Resource-based } \\
\text { theory (RBT) }\end{array}$ & $\begin{array}{l}\text { Benefits, external influence, top } \\
\text { management commitment, supplier } \\
\text { selection, supplier development, } \\
\text { performance review, economical } \\
\text { sustainability, social sustainability, and } \\
\text { environmental sustainability }\end{array}$ & $\begin{array}{l}\text { The main goal of this paper } \\
\text { is to find the import factors } \\
\text { which influence } \\
\text { sustainability adoption and } \\
\text { interrelationships between } \\
\text { them. }\end{array}$ & $\begin{array}{l}\text { Need to focus on sustainability } \\
\text { adoption in supply chain. }\end{array}$ & $\begin{array}{l}\text { Findings of this paper demonstrated that } \\
\text { expected sustainability benefits and external } \\
\text { influence have a positive relationship } \\
\text { between commitment of top management } \\
\text { towards adoption of sustainable practices } \\
\text { and better buyer-supplier relationship had } \\
\text { positive relationship with social, } \\
\text { environmental and economic performance } \\
\text { measures. }\end{array}$ \\
\hline Chiou et al. [125] & $\begin{array}{l}\text { Purchasing } \\
\text { department }\end{array}$ & 124 & $\begin{array}{l}\text { Purchasing } \\
\text { department }\end{array}$ & None & $\begin{array}{l}\text { Greening the supplier, product } \\
\text { innovation, process innovation, } \\
\text { managerial innovation, environmental } \\
\text { performance and competitive } \\
\text { advantage. }\end{array}$ & $\begin{array}{l}\text { The main goal of this study } \\
\text { is to examine green } \\
\text { innovation and greening the } \\
\text { suppliers on competitive } \\
\text { advantage and } \\
\text { environmental performance. }\end{array}$ & $\begin{array}{l}\text { Few previous studies focused } \\
\text { on green innovation, greening } \\
\text { the supply chain, competitive } \\
\text { advantage and environmental } \\
\text { performance. }\end{array}$ & $\begin{array}{l}\text { Findings of this paper showed that there was } \\
\text { the indirect affected between greening the } \\
\text { supplier and green innovation leads to better } \\
\text { competitive advantage. }\end{array}$ \\
\hline $\begin{array}{l}\text { Gavronski } \\
\text { et al. [126] }\end{array}$ & $\begin{array}{c}\text { Manufacturing } \\
\text { plants }\end{array}$ & 94 & Operation managers & $\begin{array}{l}\text { Resource based view } \\
\text { of the firm (RBV) }\end{array}$ & $\begin{array}{l}\text { Plant size, internal knowledge } \\
\text { exchange, external knowledge } \\
\text { exchange, top management } \\
\text { commitment, environmental } \\
\text { investments }\end{array}$ & $\begin{array}{l}\text { The main objective of this } \\
\text { study is to present the } \\
\text { framework for development } \\
\text { of green supply } \\
\text { management capabilities. }\end{array}$ & $\begin{array}{l}\text { There is a need to focus on } \\
\text { green supply management by } \\
\text { managers for developing a } \\
\text { greener supply chain. }\end{array}$ & $\begin{array}{l}\text { Results of this study found that plant } \\
\text { resources had positive relationship with } \\
\text { green manufacturing capabilities and GSM } \\
\text { capabilities. }\end{array}$ \\
\hline
\end{tabular}


Table A1. Breakdown of articles based on green and sustainable SCM.

\begin{tabular}{|c|c|c|c|c|c|c|c|c|}
\hline Author(s) Year & Scope and Sample & Sample Size & Respondents & Related Theory & Variables & Study Purpose & Gap and Research Problem & Results and Outcome \\
\hline Yang et al. [127] & $\begin{array}{c}\text { Container shipping } \\
\text { firms }\end{array}$ & 163 & Shipping managers & None & $\begin{array}{l}\text { Internal green practices, green } \\
\text { shipping practices, green marketing, } \\
\text { external green collaboration, green } \\
\text { collaboration with partner, green } \\
\text { collaboration with customer, green } \\
\text { performance and competitiveness, } \\
\text { decrease of green cost and firm } \\
\text { competitiveness. }\end{array}$ & $\begin{array}{l}\text { The main purpose of this } \\
\text { study is to examine the } \\
\text { relationship between } \\
\text { external green integration, } \\
\text { internal green practices, firm } \\
\text { competitiveness and green } \\
\text { performance. }\end{array}$ & $\begin{array}{l}\text { There is lack in previous } \\
\text { studies to identify the } \\
\text { relationship external green } \\
\text { collaboration, green } \\
\text { performance, internal green } \\
\text { practices, and firm } \\
\text { competitiveness in the context } \\
\text { of the container shipping } \\
\text { industry. }\end{array}$ & $\begin{array}{l}\text { Findings of this paper demonstrated that } \\
\text { there was a positive relationship between } \\
\text { external green collaboration and internal } \\
\text { green practices and green performance, and } \\
\text { green performance and external green } \\
\text { collaboration act as mediator between firm } \\
\text { competitiveness and internal green practices. }\end{array}$ \\
\hline Luo et al. [128] & $\begin{array}{c}\text { Manufacturing } \\
\text { organizations }\end{array}$ & 222 & $\begin{array}{l}\text { Directors and } \\
\text { managers }\end{array}$ & $\begin{array}{l}\text { Transaction cost } \\
\text { theory }\end{array}$ & $\begin{array}{l}\text { Asset specificity, volume uncertainty, } \\
\text { transaction frequency, competitive } \\
\text { environment, guanxi and green supply } \\
\text { chain collaboration. }\end{array}$ & $\begin{array}{l}\text { This study assesses the } \\
\text { factors influencing green } \\
\text { supply chain collaboration } \\
\text { in China }\end{array}$ & $\begin{array}{l}\text { Few previous papers have } \\
\text { attention pay to investigating } \\
\text { the buyer-seller relationship in } \\
\text { GSCC. }\end{array}$ & $\begin{array}{l}\text { The result shows that the buyer-seller } \\
\text { relationship influences green supply chain } \\
\text { collaboration through asset specificity, } \\
\text { volume uncertainty, transaction frequency } \\
\text { and competitive environment. The results } \\
\text { also showed support for our hypotheses that } \\
\text { guanini mediates the effect of asset specificity, } \\
\text { volume uncertainty and environmental } \\
\text { competition on GSCC. }\end{array}$ \\
\hline Dai et al. [129] & $\begin{array}{l}\text { Publicly traded } \\
\text { firms }\end{array}$ & 230 & $\begin{array}{l}\text { Supply chain } \\
\text { management } \\
\text { professional }\end{array}$ & Stakeholder theory & $\begin{array}{l}\text { Stakeholder pressure, competitive } \\
\text { pressure (rival pressure), top } \\
\text { management support, environmental } \\
\text { monitoring on supppliers, supplier } \\
\text { involvement on green product } \\
\text { development, environmental } \\
\text { collaborative planning with suppliers } \\
\text { and firm size (log sales). }\end{array}$ & $\begin{array}{l}\text { The main goal of this paper } \\
\text { is to investigate the role of } \\
\text { stakeholder and rivalry } \\
\text { pressure encouraged firms to } \\
\text { implement practices of green } \\
\text { supply management, and } \\
\text { examine how top } \\
\text { management support is } \\
\text { important factor for firms to } \\
\text { competitive pressures to } \\
\text { pursue practices of green } \\
\text { supply management. }\end{array}$ & $\begin{array}{l}\text { Need for further study to } \\
\text { emphasize on the role of top } \\
\text { management in the } \\
\text { environmental supply chain. }\end{array}$ & $\begin{array}{l}\text { Findings of this article showed that } \\
\text { environmental pressure influenced } \\
\text { implementation green supply management } \\
\text { by a mediated role of top management } \\
\text { support for environmental initiatives. }\end{array}$ \\
\hline Jabbour et al. [130] & $\begin{array}{l}\text { Firms with ISO } \\
14001\end{array}$ & 95 & $\begin{array}{l}\text { Environmental } \\
\text { Managers }\end{array}$ & None & $\begin{array}{l}\text { Quality management, environmental } \\
\text { management maturity, green supply } \\
\text { chain management--green purchasing, } \\
\text { green supply chain } \\
\text { management-customers' } \\
\text { collaboration and green performance. }\end{array}$ & $\begin{array}{l}\text { The main objective of this } \\
\text { paper is to present the novel } \\
\text { conceptual framework based } \\
\text { on the relationship of } \\
\text { environmental management } \\
\text { maturity, quality } \\
\text { management, adoption of } \\
\text { external practices of green } \\
\text { supply chain management } \\
\text { and green performance. }\end{array}$ & $\begin{array}{l}\text { There is lack in previous } \\
\text { studies regarding the } \\
\text { relationship between } \\
\text { environmental management } \\
\text { maturity, quality management, } \\
\text { adoption of external practices } \\
\text { of green supply chain } \\
\text { management and green } \\
\text { performance. }\end{array}$ & $\begin{array}{l}\text { Results of this paper found that quality } \\
\text { management was a significant factor for } \\
\text { environmental management maturity and } \\
\text { impact on adoption of external GSCM } \\
\text { practices and influence on green performance. } \\
\text { In addition, indirectly, the level of } \\
\text { environmental management maturity } \\
\text { mediates the relatianship between QM and } \\
\text { the adoption of GSCM practices and GSCM } \\
\text { practices mediate the relationship between } \\
\text { the level of environmental management } \\
\text { maturity and the green performance of firms. }\end{array}$ \\
\hline Zhu et al. [131] & $\begin{array}{c}\text { Chinese } \\
\text { manufacturer }\end{array}$ & 396 & $\begin{array}{l}\text { Mid-level or senior } \\
\text { managers }\end{array}$ & Institutional theory & $\begin{array}{l}\text { Institutional pressure, eco-design, } \\
\text { internal environmental management, } \\
\text { green purchasing, customer } \\
\text { cooperation with environmental } \\
\text { concerns and investment recovery. }\end{array}$ & $\begin{array}{l}\text { The main goal of this paper } \\
\text { is to examine the various } \\
\text { kinds of institutional } \\
\text { pressures motivating } \\
\text { manufacturing enterprises to } \\
\text { pursue green supply chain } \\
\text { management practices and } \\
\text { performance. }\end{array}$ & $\begin{array}{l}\text { Need to focus on developing } \\
\text { diffusion and performance } \\
\text { from implementing GSCM. }\end{array}$ & $\begin{array}{l}\text { Results of this article indicated that } \\
\text { institutional pressures have driven the } \\
\text { manufacturer adoption of internal GSCM and } \\
\text { external GSCM practices adoption and } \\
\text { GSCM has not the direct relationship with } \\
\text { economic performance. }\end{array}$ \\
\hline
\end{tabular}


Table A1. Breakdown of articles based on green and sustainable SCM.

\begin{tabular}{|c|c|c|c|c|c|c|c|c|}
\hline Author(s) Year & Scope and Sample & Sample Size & Respondents & Related Theory & Variables & Study Purpose & Gap and Research Problem & Results and Outcome \\
\hline Caniëls et al. [132] & $\begin{array}{l}\text { German automotive } \\
\text { suppliers }\end{array}$ & 54 & $\begin{array}{l}\text { Automotive } \\
\text { suppliers }\end{array}$ & $\begin{array}{c}\text { Resource } \\
\text { Dependence Theory }\end{array}$ & $\begin{array}{l}\text { Customer requirements, supplier } \\
\text { readiness, relational norms (arm's } \\
\text { length), relational norms (cooperation), } \\
\text { customer investment and supplier } \\
\text { participation. }\end{array}$ & $\begin{array}{l}\text { The aim of this study is to } \\
\text { explore the role of supplier } \\
\text { participation in green } \\
\text { initiatives by incorporating } \\
\text { of customer requirement, } \\
\text { rational norms, supplier } \\
\text { readiness and customer } \\
\text { investment. }\end{array}$ & $\begin{array}{l}\text { Due to significant ecological } \\
\text { perspectives for industrial } \\
\text { companies there is lack in } \\
\text { previous studies related to } \\
\text { internal organizational process, } \\
\text { particularly in the area of } \\
\text { green SCM. }\end{array}$ & $\begin{array}{l}\text { Findings of this study showed that customer } \\
\text { requirements and supplier readiness were } \\
\text { important drivers in supplier participation } \\
\text { and customer investment and cooperative } \\
\text { relational norms were drivers in green SCM } \\
\text { for large suppliers. }\end{array}$ \\
\hline $\begin{array}{l}\text { Gualandris and } \\
\text { Kalchschmidt [133] }\end{array}$ & $\begin{array}{l}\text { Manufacturing } \\
\text { firms }\end{array}$ & 77 & $\begin{array}{l}\text { Purchasing manager } \\
\text { or plant manager }\end{array}$ & $\begin{array}{l}\text { Stakeholder theory } \\
\text { and resource-based } \\
\text { perspective }\end{array}$ & $\begin{array}{l}\text { Sustainable supply management, } \\
\text { sustainable process management, } \\
\text { customer pressure and innovativeness. }\end{array}$ & $\begin{array}{l}\text { The main objective of this } \\
\text { article is to examine the } \\
\text { sustainable process } \\
\text { management, sustainable } \\
\text { supply management, } \\
\text { customer pressure and } \\
\text { innovativeness. }\end{array}$ & $\begin{array}{l}\text { There is lack of previous } \\
\text { studies regarding interaction } \\
\text { between different groups of } \\
\text { sustainable SCM such as } \\
\text { sustainable supply } \\
\text { management, sustainable } \\
\text { process management, } \\
\text { customer pressure and } \\
\text { innovativeness. }\end{array}$ & $\begin{array}{l}\text { Results of this paper found there was a } \\
\text { positive and significant relationship between } \\
\text { innovativeness, customer pressure and } \\
\text { sustainable process management and also } \\
\text { sustainable process management fully } \\
\text { mediates the relationships between } \\
\text { sustainable supply management and } \\
\text { innovativeness had the negative and } \\
\text { significant moderates the relationship } \\
\text { between customer pressure and sustainable } \\
\text { process management. }\end{array}$ \\
\hline $\begin{array}{l}\text { Gualandris and } \\
\text { Kalchschmidt [134] }\end{array}$ & $\begin{array}{l}\text { Italian } \\
\text { manufacturing firms }\end{array}$ & 77 & $\begin{array}{l}\text { Chief procurement } \\
\text { officer, purchasing } \\
\text { manager or buyer }\end{array}$ & $\begin{array}{l}\text { Resource-based } \\
\text { theories }\end{array}$ & $\begin{array}{l}\text { Sustainable process management, } \\
\text { sustainable supply management, firm } \\
\text { sustainability, buyer-supplier trust and } \\
\text { supplier sustainability. }\end{array}$ & $\begin{array}{l}\text { The main purpose of this } \\
\text { paper is to explore the } \\
\text { relationshipo of social and } \\
\text { environmental performance } \\
\text { of manufacturing and } \\
\text { relationship between } \\
\text { suppliers' sustainability } \\
\text { performance and } \\
\text { buyer-supplier trust. }\end{array}$ & $\begin{array}{l}\text { There is lack of understanding } \\
\text { of improve sustainability } \\
\text { performance in manufacturing } \\
\text { regarding sustainable SCM. }\end{array}$ & $\begin{array}{l}\text { Findings of this paper showed that } \\
\text { sustainability performance in manufacturing } \\
\text { firms enhanced sustainable SCM and internal } \\
\text { practices had a direct influence on } \\
\text { performance, also there was a full mediate } \\
\text { relationship between external practices and } \\
\text { sustainability performance in manufacturing } \\
\text { firms. Results show manufacturing firms' } \\
\text { sustainability performance. }\end{array}$ \\
\hline Caniëls et al. [135] & Suppliers & 93 & $\begin{array}{c}\text { Executives or } \\
\text { functional managers }\end{array}$ & Stakeholder theory & $\begin{array}{l}\text { Green SCM readiness, customer } \\
\text { requirements, governmental } \\
\text { involvement, social responsibility and } \\
\text { competitive advantage. }\end{array}$ & $\begin{array}{l}\text { The main goal of this study } \\
\text { is to analysis the drivers for } \\
\text { SC participation of suppliers } \\
\text { by involving some drivers } \\
\text { such as customer } \\
\text { requirements towards green } \\
\text { issues, green SCM readiness } \\
\text { feeling of social } \\
\text { responsibility, governmental } \\
\text { involvement in greening the } \\
\text { supply chain, and } \\
\text { competitive advantage by } \\
\text { going green. }\end{array}$ & $\begin{array}{l}\text { There is concern about } \\
\text { environmental issues and } \\
\text { green SCM in shipbuilding } \\
\text { industry. }\end{array}$ & $\begin{array}{l}\text { Results of this study found that green SCM } \\
\text { readiness, social responsibility and } \\
\text { compestitive advantage were the important } \\
\text { drivers for supplier participation, and also } \\
\text { results show that there was no significant } \\
\text { support for customer requirements and } \\
\text { governmental involvement. }\end{array}$ \\
\hline Rao and Holt [136] & $\begin{array}{l}\text { ISO14001 certified } \\
\text { companies }\end{array}$ & 52 & $\begin{array}{l}\text { Chief executive of } \\
\text { ISO } 14001\end{array}$ & None & $\begin{array}{l}\text { Greening inbound, greening outbound, } \\
\text { economic performance, greening } \\
\text { production, ompetitiveness and } \\
\text { economic performance. }\end{array}$ & $\begin{array}{l}\text { The purpose of this paper is } \\
\text { to explore the relationship } \\
\text { between green SCM } \\
\text { competitiveness and } \\
\text { economic performance. }\end{array}$ & $\begin{array}{l}\text { Few previous papers focused } \\
\text { on evaluation of green SCM } \\
\text { for increasing economic } \\
\text { performance and } \\
\text { competitiveness. }\end{array}$ & $\begin{array}{l}\text { Results of this paper demonstrated that } \\
\text { focusing on different phases of greening } \\
\text { regarding SC and green SC increase economic } \\
\text { performance and competitiveness. }\end{array}$ \\
\hline Green et al. [137] & $\begin{array}{l}\text { Manufacturing } \\
\text { organizations }\end{array}$ & 159 & $\begin{array}{l}\text { Plant-level } \\
\text { managers }\end{array}$ & Stakeholder theory & $\begin{array}{l}\text { Internal environmental management, } \\
\text { green information systems, } \\
\text { environmental cooperation with } \\
\text { suppliers, environmental cooperation } \\
\text { with customers, environmental } \\
\text { monitoring of suppliers, environmental } \\
\text { monitoring of customers, } \\
\text { environmental performance; and } \\
\text { organizational performance. }\end{array}$ & $\begin{array}{l}\text { The main objective of this } \\
\text { study is to explore the } \\
\text { relationship between GSCM, } \\
\text { environmental management } \\
\text { and organizational } \\
\text { performance. }\end{array}$ & $\begin{array}{l}\text { Need to implement } \\
\text { environmental collaboration } \\
\text { and monitoring practices } \\
\text { regarding the SC partners. }\end{array}$ & $\begin{array}{l}\text { Results of this paper found that monitoring } \\
\text { practices and environmental collaboration } \\
\text { enhanced the organizational and } \\
\text { environmental performance. }\end{array}$ \\
\hline
\end{tabular}


Table A1. Breakdown of articles based on green and sustainable SCM.

\begin{tabular}{|c|c|c|c|c|c|c|c|c|}
\hline Author(s) Year & Scope and Sample & Sample Size & Respondents & Related Theory & Variables & Study Purpose & Gap and Research Problem & Results and Outcome \\
\hline Lee et al. [138] & Electronics industry & 223 & $\begin{array}{l}\text { Operations/supply } \\
\text { chain managers }\end{array}$ & $\begin{array}{c}\text { Resource } \\
\text { dependence theory }\end{array}$ & $\begin{array}{l}\text { GSCM practice, business performance, } \\
\text { operational efficiency, mployee } \\
\text { satisfactioo and relational efficiency. }\end{array}$ & $\begin{array}{l}\text { The main goal of this paper } \\
\text { is to examine the } \\
\text { relationship of practices of } \\
\text { GSCM and organizational } \\
\text { performance by moderating } \\
\text { effect of operational } \\
\text { efficiency, employee } \\
\text { satisfaction and relational } \\
\text { efficiency. }\end{array}$ & $\begin{array}{l}\text { Need to focus on supplier } \\
\text { perspective in investigating } \\
\text { the weaknesses of SME for } \\
\text { enhancing SME suppliers' } \\
\text { green management } \\
\text { capabilities. }\end{array}$ & $\begin{array}{l}\text { Results of this paper found that there was a } \\
\text { direct relationship between GSCM practices } \\
\text { and business performance, there was } \\
\text { significant indirect relationship between } \\
\text { GSCM and business performance by } \\
\text { incorporating of relational efficiency and } \\
\text { operational efficieincy. }\end{array}$ \\
\hline Green et al. [139] & $\begin{array}{c}\text { Manufacturing } \\
\text { organizations }\end{array}$ & 159 & $\begin{array}{l}\text { Manufacturing } \\
\text { managers }\end{array}$ & RBV & $\begin{array}{l}\text { Internal environmental management, } \\
\text { green information systems, green } \\
\text { purchasing, cooperation with } \\
\text { customers, eco-design, investment } \\
\text { recovery, environmental performance, } \\
\text { economic performance, operational } \\
\text { performance and organizational } \\
\text { performance. }\end{array}$ & $\begin{array}{l}\text { The main purpose of this } \\
\text { study is to explore the } \\
\text { influence of GSCM on } \\
\text { performance. }\end{array}$ & $\begin{array}{l}\text { Need to explore the } \\
\text { relationship between GSCM } \\
\text { and performance. }\end{array}$ & $\begin{array}{l}\text { Results of this paper found that adoption of } \\
\text { GSCM practices improved the economic and } \\
\text { environmental performance and had a } \\
\text { positive influence on operational } \\
\text { performance and operational performance } \\
\text { improved organizational performance. }\end{array}$ \\
\hline Lee et al. [140] & $\begin{array}{l}\text { ISO } 14001 \\
\text { manufacturing firms }\end{array}$ & 119 & $\begin{array}{c}\text { Managerial } \\
\text { positions }\end{array}$ & None & $\begin{array}{l}\text { Environmental performance, greening } \\
\text { the supplier and competitive } \\
\text { advantage. }\end{array}$ & $\begin{array}{l}\text { The main aim of this article } \\
\text { is to explore the relationship } \\
\text { among three factors } \\
\text { including environmental } \\
\text { performance, greening the } \\
\text { supplier and competitive } \\
\text { advantage. }\end{array}$ & $\begin{array}{l}\text { Need for a clear study to } \\
\text { identify and confirm the } \\
\text { structural relationships among } \\
\text { environmental performance, } \\
\text { greening the supplier and } \\
\text { competitive advantage. }\end{array}$ & $\begin{array}{l}\text { Findings of this paper showed that there was } \\
\text { a positive and significant relationship } \\
\text { between green supplier, environmental } \\
\text { performance and competitive advantage, and } \\
\text { there was a significant and positive between } \\
\text { environmental performance and competitive } \\
\text { advantage; however, environmental } \\
\text { performance had a partial mediating effect } \\
\text { between competitive advantage and green } \\
\text { supplier. }\end{array}$ \\
\hline $\begin{array}{l}\text { Villanueva-Ponce } \\
\text { et al. [141] }\end{array}$ & Industrial sectors & 206 & $\begin{array}{c}\text { Purchasing } \\
\text { managers }\end{array}$ & Contingent theory & $\begin{array}{l}\text { Traditional attributes, green product } \\
\text { design, green attributes, financial } \\
\text { profits and corporative image. }\end{array}$ & $\begin{array}{l}\text { The main purpose of this } \\
\text { paper is to investigate the } \\
\text { relationship among } \\
\text { traditional attributes, green } \\
\text { product design, green } \\
\text { attributes, financial profits } \\
\text { and corporative image. }\end{array}$ & $\begin{array}{l}\text { There is lack of company } \\
\text { awareness related to potential } \\
\text { benefits of environmental } \\
\text { attributes and regulations } \\
\text { regarding the selection of } \\
\text { supplier. }\end{array}$ & $\begin{array}{l}\text { Results of this paper demonstrated that } \\
\text { companies enhance their corporative image } \\
\text { and profits of environmental attributes based } \\
\text { on supplier selection criteria for improving } \\
\text { the quality of production process. }\end{array}$ \\
\hline $\begin{array}{l}\text { Gimenez and } \\
\text { Sierra [142] }\end{array}$ & $\begin{array}{l}\text { Manufacturing } \\
\text { sector }\end{array}$ & 109 & $\begin{array}{c}\text { purchasing and } \\
\text { supply Managers }\end{array}$ & $\begin{array}{l}\text { RBV, Transaction } \\
\text { Cost Theory, social } \\
\text { network theory }\end{array}$ & $\begin{array}{l}\text { Supplier assessment, collaboration } \\
\text { with suppliers and environmental } \\
\text { performance. }\end{array}$ & $\begin{array}{l}\text { The main objective of this } \\
\text { paper is to explore the } \\
\text { relationship between } \\
\text { Supplier assessment, } \\
\text { collaboration with suppliers } \\
\text { and environmental } \\
\text { performance. }\end{array}$ & $\begin{array}{l}\text { There is lack in the literature } \\
\text { regarding comparison of the } \\
\text { influence of various } \\
\text { governance mechanisms } \\
\text { which firms can modify to } \\
\text { green suppliers and enhancing } \\
\text { of environmental performance. }\end{array}$ & $\begin{array}{l}\text { Results of this paper found that supplier } \\
\text { collaboration and assessment had a positive } \\
\text { and significant influence on environmental } \\
\text { performance. }\end{array}$ \\
\hline Hollos et al. [143] & $\begin{array}{l}\text { Industrial } \\
\text { companies }\end{array}$ & 70 & $\begin{array}{l}\text { Senior purchasing } \\
\text { managers and } \\
\text { executives }\end{array}$ & $\begin{array}{c}\text { Resource } \\
\text { dependence theory } \\
\text { and the } \\
\text { resource-based view }\end{array}$ & $\begin{array}{l}\text { Strategic orientation, sustainable } \\
\text { supplier co-operation, green practices, } \\
\text { social practices, cost reduction and } \\
\text { operational performance. }\end{array}$ & $\begin{array}{l}\text { The main purpose of this } \\
\text { paper is to examine the } \\
\text { relationship between } \\
\text { sustainable supplier } \\
\text { co-operation and } \\
\text { performance. }\end{array}$ & $\begin{array}{l}\text { Few previous studies have } \\
\text { focused on an economic } \\
\text { perspective regarding } \\
\text { sustainability. }\end{array}$ & $\begin{array}{l}\text { Findings of this paper indicated that there } \\
\text { was positive relationship between sustainable } \\
\text { supplier co-operation and performance, and } \\
\text { only there was the positive and significant } \\
\text { relationship between green practices and } \\
\text { economic performance. }\end{array}$ \\
\hline $\begin{array}{l}\text { Abareshi and } \\
\text { Molla [144] }\end{array}$ & $\begin{array}{l}\text { Transport and } \\
\text { Logistics firms }\end{array}$ & 279 & Managers & Absorptive capacity & $\begin{array}{l}\text { Green logistics knowledge assimilation, } \\
\text { green logistics knowledge } \\
\text { transformation, green logistics } \\
\text { knowledge acquisition and green } \\
\text { logistics performance. }\end{array}$ & $\begin{array}{l}\text { The main objective of this } \\
\text { study is to examine the role } \\
\text { of absorptive capacity in } \\
\text { implementation green } \\
\text { logistics practices on the } \\
\text { green logistics performance. }\end{array}$ & $\begin{array}{l}\text { Few previous studies focused } \\
\text { on green logistics practices in } \\
\text { logistics and transport firms. }\end{array}$ & $\begin{array}{l}\text { Results of this paper found that improving } \\
\text { green logistics knowledge exploitation was } \\
\text { the important factor for enhancing green } \\
\text { logistics performance. }\end{array}$ \\
\hline
\end{tabular}


Table A1. Breakdown of articles based on green and sustainable SCM.

\begin{tabular}{|c|c|c|c|c|c|c|c|c|}
\hline Author(s) Year & Scope and Sample & Sample Size & Respondents & Related Theory & Variables & Study Purpose & Gap and Research Problem & Results and Outcome \\
\hline $\begin{array}{l}\text { Tachizawa } \\
\text { et al. [145] }\end{array}$ & University & 71 & $\begin{array}{l}\text { Purchasing } \\
\text { Managers }\end{array}$ & Institutional Theory & $\begin{array}{l}\text { Drivers' mimetic coercive normative, } \\
\text { monitoring, collaboration and } \\
\text { environmental performance. }\end{array}$ & $\begin{array}{l}\text { The main objective of this } \\
\text { paper is to explore the } \\
\text { interrelationships among } \\
\text { green SCM, environmental } \\
\text { drivers and performance. }\end{array}$ & $\begin{array}{l}\text { There is a lack in previous } \\
\text { studies regarding non-coercive } \\
\text { and coercive derivers have } \\
\text { influence on GSCM } \\
\text { approaches. }\end{array}$ & $\begin{array}{l}\text { Findings of this study showed that } \\
\text { non-coercive and coercive derivers have } \\
\text { diverse implications regarding green SCM, in } \\
\text { addition, monitoring cannot enhance the } \\
\text { performance, also there was direct } \\
\text { relationship between collaboration and } \\
\text { performance and there was indirect } \\
\text { relationship between monitoring and } \\
\text { collaboration. }\end{array}$ \\
\hline Hsu et al. [146] & $\begin{array}{l}\text { EMS ISO } 14001 \\
\text {-certified firms }\end{array}$ & 125 & Managers & $\begin{array}{l}\text { Strategic choice } \\
\text { theory }\end{array}$ & $\begin{array}{l}\text { Eco-reputation strategic orientation, } \\
\text { eco-innovation strategic orientation, } \\
\text { green purchasing, green } \\
\text { manufacturing, green packaging and } \\
\text { reverse logistics. }\end{array}$ & $\begin{array}{l}\text { The main objective of this } \\
\text { study is to develop the } \\
\text { theoretical framework to } \\
\text { predict the relationship } \\
\text { between sustainable supply } \\
\text { chain initiatives and reverse } \\
\text { logistics outcome and the } \\
\text { relationship between } \\
\text { eco-innovation and } \\
\text { eco-reputation orientation } \\
\text { strategies and sustainable } \\
\text { supply chain initiatives. }\end{array}$ & $\begin{array}{l}\text { Need to focus on the critical } \\
\text { role of eco-reputation and } \\
\text { eco-innovation strategic } \\
\text { orientations in deploying } \\
\text { sustainable supply chain } \\
\text { initiative programs. }\end{array}$ & $\begin{array}{l}\text { Results of this paper indicated that there was } \\
\text { a positive relationship between sustaining } \\
\text { firms' SC initiatives and the individual } \\
\text { sustainable supply chain initiative } \\
\text { components, and there was a positive } \\
\text { relationshiph green packing and green } \\
\text { manufacturing and firms' reverse logistics } \\
\text { outcomes, also there was no significant } \\
\text { relationship with reverse logistics. }\end{array}$ \\
\hline Hsu et al. [147] & $\begin{array}{l}\text { ISO } 14001 \text { certified } \\
\text { organizations }\end{array}$ & 569 & Senior manager & Institutional theory & $\begin{array}{l}\text { Regulatory measures, customer } \\
\text { pressures, competitor pressures, } \\
\text { socio-cultural responsibility, green } \\
\text { supply chain drivers, green purchasing, } \\
\text { design for environment and reverse } \\
\text { logistics. }\end{array}$ & $\begin{array}{l}\text { The main objective of this } \\
\text { study is to explore the } \\
\text { motivate drivers to adopt } \\
\text { green SCM for measuring by } \\
\text { the second order construct to } \\
\text { the implementing of the } \\
\text { firm's green SC initiatives. }\end{array}$ & $\begin{array}{l}\text { Although the important } \\
\text { environmental sustainability } \\
\text { in emerging economics is clear } \\
\text { regarding economic benefits, } \\
\text { study of the drivers that } \\
\text { impact green SC initiatives in a } \\
\text { developing economy is still an } \\
\text { under-researched area. } \\
\end{array}$ & $\begin{array}{l}\text { Results of this paper found that green SCM } \\
\text { drivers had a positive relationship with green } \\
\text { purchasing, also the SCM driver had a } \\
\text { positive impact on design for the } \\
\text { environment, and the green SCM driver had } \\
\text { a positive influence on reverse logistics } \\
\text { initiative. }\end{array}$ \\
\hline Kirchoff et al. [148] & $\begin{array}{l}\text { Manufacturing } \\
\text { firms }\end{array}$ & 367 & $\begin{array}{l}\text { Supply chain } \\
\text { managers }\end{array}$ & $\begin{array}{l}\text { Resource-based and } \\
\text { strategic choice } \\
\text { theories }\end{array}$ & $\begin{array}{l}\text { Environmental orientation, supply } \\
\text { chain orientation, green SCM, cost } \\
\text { efficieincy, customer effectiveness and } \\
\text { environmental differentiation. }\end{array}$ & $\begin{array}{l}\text { The main purpose of this } \\
\text { study is to use two theories } \\
\text { including RBV and strategic } \\
\text { choice for better } \\
\text { understanding of SC } \\
\text { orientation, environmental } \\
\text { orientation and strategic } \\
\text { orientation on green SCM } \\
\text { practices. }\end{array}$ & $\begin{array}{l}\text { While previous studies } \\
\text { confirmed the positive } \\
\text { relationship green SCM and } \\
\text { firm performance, there are } \\
\text { some questions remain } \\
\text { regarding how firms configure } \\
\text { the designg green and their } \\
\text { organizations to attain } \\
\text { enhanced performance, } \\
\text { particularity in lighting of a } \\
\text { constantly changing business } \\
\text { environment. }\end{array}$ & $\begin{array}{l}\text { Results of this study found that integration of } \\
\text { SC orientation, environmental orientation } \\
\text { had a positive relationship with green SCM } \\
\text { practices such as firm performance. }\end{array}$ \\
\hline $\begin{array}{l}\text { Pazirandeh and } \\
\text { Jafari [149] }\end{array}$ & $\begin{array}{c}\text { Nordic } \\
\text { multinationals } \\
\text { companies }\end{array}$ & 97 & Logistics managers & None & $\begin{array}{l}\text { Sustainability strategy, Greening } \\
\text { transport operations, Greening } \\
\text { Transport procurement and Logistics } \\
\text { efficiency. }\end{array}$ & $\begin{array}{l}\text { The main objective of this } \\
\text { article is to evaluate the } \\
\text { relationship between } \\
\text { sustainability strategy, } \\
\text { greening the transportation } \\
\text { activities logistics efficiency } \\
\text { and logistics effectiveness. }\end{array}$ & $\begin{array}{l}\text { The lack of previous studies } \\
\text { regarding the relationship } \\
\text { logistics performance, } \\
\text { sustainable strategy and } \\
\text { greening the transportation } \\
\text { activities. }\end{array}$ & $\begin{array}{l}\text { Results of this study demonstrated that there } \\
\text { was significant relationship between all } \\
\text { relationships such as sustainability strategy } \\
\text { to greening transport procurement, } \\
\text { sustainability strategy to greening transport } \\
\text { operations, greening transport procurement, } \\
\text { logistics efficiency and logistics effectiveness } \\
\text { greener transport procurement and logistics } \\
\text { performance, greening transport operations } \\
\text { and logistics sefficiency and logistics } \\
\text { effectiveness. }\end{array}$ \\
\hline
\end{tabular}


Table A1. Breakdown of articles based on green and sustainable SCM.

\begin{tabular}{|c|c|c|c|c|c|c|c|c|}
\hline Author(s) Year & Scope and Sample & Sample Size & Respondents & Related Theory & Variables & Study Purpose & Gap and Research Problem & Results and Outcome \\
\hline Ateş et al. [150] & Manufacturers & 96 & $\begin{array}{l}\text { Purchasing manager } \\
\text { and environmental } \\
\text { manager }\end{array}$ & Contingency theory & $\begin{array}{l}\text { Environmental performance, internal } \\
\text { investments, external investments, } \\
\text { proactive environmental strategies, } \\
\text { customer pressure and organisational } \\
\text { commitment. }\end{array}$ & $\begin{array}{l}\text { The main objective of this } \\
\text { paper is to examine the effect } \\
\text { of proactive environmental } \\
\text { strategy on environmental } \\
\text { performance by mediating } \\
\text { role of environmental } \\
\text { investments. }\end{array}$ & $\begin{array}{l}\text { There is a lack in previous } \\
\text { literature regarding the impact } \\
\text { of proactive environmental } \\
\text { strategy on environmental } \\
\text { performance in relationship } \\
\text { between environmental } \\
\text { management and SCM. }\end{array}$ & $\begin{array}{l}\text { Findings of this paper showed that a } \\
\text { proactive environmental strategy served } \\
\text { higher environmental investments. There } \\
\text { was a mediating of environmental } \\
\text { investments in the relationship between } \\
\text { environmental performance and proactive } \\
\text { environmental strategy, also there were } \\
\text { positive relationship between proactive } \\
\text { environmental strategy, customer pressure } \\
\text { and organizational commitment. }\end{array}$ \\
\hline Lee [151] & Supplying firms & 207 & $\begin{array}{l}\text { CEO or the senior } \\
\text { manager }\end{array}$ & Social capital theory & $\begin{array}{l}\text { Green SCM, structural social capital, } \\
\text { supplier's environmental performance, } \\
\text { relational social capitatand and supplier's } \\
\text { operational performance. }\end{array}$ & $\begin{array}{l}\text { The main objectives of this } \\
\text { article is to investigate the } \\
\text { relationship between green } \\
\text { SCM operational and } \\
\text { environmental performance } \\
\text { with incorporating social } \\
\text { capital theory. }\end{array}$ & $\begin{array}{l}\text { There is a lack in previous } \\
\text { studies regarding of social } \\
\text { capital in relationship between } \\
\text { green SCM and operational } \\
\text { and environmental } \\
\text { performance. }\end{array}$ & $\begin{array}{l}\text { Results of this paper found that green } \mathrm{SCM} \\
\text { contributes to operational and environmental } \\
\text { performance through social capital theory. }\end{array}$ \\
\hline Yu et al. [152] & $\begin{array}{l}\text { Automotive } \\
\text { manufacturers }\end{array}$ & 126 & $\begin{array}{l}\text { General managers } \\
\text { or directors }\end{array}$ & Stakeholder theory & $\begin{array}{l}\text { Internal GSCM, GSCM with customers, } \\
\text { GSCM with suppliers, operational } \\
\text { flexibility, delivery, product quality and } \\
\text { production cost }\end{array}$ & $\begin{array}{l}\text { The main objective of this } \\
\text { article is to examine the } \\
\text { relationship between } \\
\text { integrated green SCM and } \\
\text { operational performance. }\end{array}$ & $\begin{array}{l}\text { There is a lack in previous } \\
\text { studies regarding the } \\
\text { integrating of three main } \\
\text { dimensions including Internal } \\
\text { GSCM, GSM with customers } \\
\text { and GSCM with suppliers with } \\
\text { effect on operational } \\
\text { performance dimensions. }\end{array}$ & $\begin{array}{l}\text { Results of this article show that there was a } \\
\text { significant and positive relationship between } \\
\text { integrated green SCM and operational } \\
\text { performance. }\end{array}$ \\
\hline Amann et al. [153] & Public sector & 281 & EU member & $\begin{array}{l}\text { Inducement } \\
\text { contribution theory }\end{array}$ & $\begin{array}{l}\text { Policy goals inclusion in the tender, } \\
\text { policy goals inclusion in offers and } \\
\text { policy goals achievement through the } \\
\text { award. }\end{array}$ & $\begin{array}{l}\text { The main purpose of this } \\
\text { article is to present the } \\
\text { relationship between } \\
\text { sustainability policy goals } \\
\text { including in public } \\
\text { procurement tenders and } \\
\text { offers and their achievement } \\
\text { through contract award. }\end{array}$ & $\begin{array}{l}\text { There is a lack in the literature } \\
\text { regarding the sustainability } \\
\text { policy in public procurement. }\end{array}$ & $\begin{array}{l}\text { Findings of this article show that public } \\
\text { procurement was more effective in } \\
\text { influencing socially responsible goals than } \\
\text { environmental goals. }\end{array}$ \\
\hline $\begin{array}{l}\text { Gopal and } \\
\text { Thakkar [154] }\end{array}$ & $\begin{array}{l}\text { Automobile } \\
\text { industry }\end{array}$ & 103 & $\begin{array}{l}\text { Supply chain } \\
\text { managers }\end{array}$ & None & $\begin{array}{l}\text { Sustainable supply chain practices, } \\
\text { sustainable supply chain enablers, } \\
\text { supply chain performance, sustainable } \\
\text { supply chain inhibitors, economic } \\
\text { indicator, environmental indicator and } \\
\text { social indicators. }\end{array}$ & $\begin{array}{l}\text { The main goal of this article } \\
\text { is to analysis the relationship } \\
\text { between sustainable supply } \\
\text { chain management practices } \\
\text { and sustainability } \\
\text { performance. }\end{array}$ & $\begin{array}{l}\text { Little attention has been paid } \\
\text { to the relationship between } \\
\text { sustainable supply chain and } \\
\text { organizational performance. }\end{array}$ & $\begin{array}{l}\text { Findings of this paper found that there was a } \\
\text { correlation between sustainable supply chain } \\
\text { practices and supply chain performance, } \\
\text { there was positive relationship between } \\
\text { social, environmental and economic } \\
\text { performance. }\end{array}$ \\
\hline Khaksar et al. [155] & Cement industry & 103 & Managers & None & $\begin{array}{l}\text { Green supplier, green innovation, } \\
\text { environmental performance and } \\
\text { competitive advantage. }\end{array}$ & $\begin{array}{l}\text { The main objective of this } \\
\text { paper is to examine the } \\
\text { relationship between green } \\
\text { innovation, green supplier, } \\
\text { competitive advantage and } \\
\text { environmental performance. }\end{array}$ & $\begin{array}{l}\text { There is a lack in previous } \\
\text { literature regarding Green } \\
\text { supplier, green innovation, } \\
\text { environmental performance } \\
\text { and competitive advantage. }\end{array}$ & $\begin{array}{l}\text { Findings of this paper showed that there was } \\
\text { a significiant and positive relationship } \\
\text { between green innovation, green supplier } \\
\text { and environmental performance. }\end{array}$ \\
\hline
\end{tabular}


Table A2. Breakdown of articles based on CSR.

\begin{tabular}{|c|c|c|c|c|c|c|c|c|}
\hline Author(s) Year & Scope and Sample & Sample Size & Respondents & Related Theory & Variables & Study Purpose & $\begin{array}{c}\text { Gap and Research } \\
\text { Problem }\end{array}$ & Results and Outcome \\
\hline Zhu et al. [166] & $\begin{array}{l}\text { Chinese national } \\
\text { state-owned } \\
\text { enterprises } \\
\text { (CNSOEs) }\end{array}$ & $\begin{array}{l}100 \text { Chinese } \\
\text { national } \\
\text { state-owned } \\
\text { enterprises } \\
\text { (CNSOEs) }\end{array}$ & General managers & $\begin{array}{l}\text { Stakeholder } \\
\text { theory }\end{array}$ & $\begin{array}{l}\text { Organizational governance, } \\
\text { Human rights, Labor practices, The } \\
\text { environment, Fair operating } \\
\text { practices, Consumer issues, } \\
\text { Community involvement and } \\
\text { development, Supply chain and } \\
\text { Political responsibility. }\end{array}$ & $\begin{array}{l}\text { Developed the new } \\
\text { framework based for CSR } \\
\text { and social and financial } \\
\text { performance improvement } \\
\text { based on stockholder } \\
\text { theory. }\end{array}$ & $\begin{array}{l}\text { There is a lack in previous } \\
\text { studies regarding the CSR } \\
\text { practices model in } \\
\text { developing countries. }\end{array}$ & $\begin{array}{l}\text { Findings of this paper showed that labor } \\
\text { practices, communuty involvement and } \\
\text { development, supply chain and political } \\
\text { responsibility had a positive relationship } \\
\text { with social performance and all CSR practices } \\
\text { had the positive relationship with financial } \\
\text { performance. }\end{array}$ \\
\hline Kang et al. [165] & Hotel industry & 200 & $\begin{array}{l}\text { Customers, } \\
\text { employees and } \\
\text { managers }\end{array}$ & $\begin{array}{l}\text { Stakeholder } \\
\text { theory }\end{array}$ & $\begin{array}{l}\text { Corporate Social Responsibility, } \\
\text { Financial dimensions, Customer } \\
\text { dimensions, Business dimensions, } \\
\text { Learning \& Growth dimensions. }\end{array}$ & $\begin{array}{l}\text { Investigated the } \\
\text { relationship between CSR } \\
\text { and business performance } \\
\text { by using Sustainability } \\
\text { Balanced Scorecard. }\end{array}$ & $\begin{array}{l}\text { There is a need to refine } \\
\text { the suitable for } \\
\text { relationship between CSR } \\
\text { and CFP. }\end{array}$ & $\begin{array}{l}\text { There is a significant relationship between } \\
\text { CSR and business performance in three } \\
\text { groups by using balance score card. }\end{array}$ \\
\hline $\begin{array}{l}\text { Gallardo-Vázquez and } \\
\text { Sanchez-Hernandez [167] }\end{array}$ & $\begin{array}{l}\text { Medium and big } \\
\text { firms }\end{array}$ & 67 & Managers & $\begin{array}{l}\text { Theory of } \\
\text { resources and } \\
\text { capabilities }\end{array}$ & $\begin{array}{l}\text { Corporate Social Responsibility, } \\
\text { Performance and Competitive } \\
\text { success. }\end{array}$ & $\begin{array}{l}\text { The main aim of this paper } \\
\text { is to examine the } \\
\text { relationship between CSR, } \\
\text { competitive success and } \\
\text { firm performance. }\end{array}$ & $\begin{array}{l}\text { Need to define the overall } \\
\text { scale of CSR dimensions in } \\
\text { the specific regional level. }\end{array}$ & $\begin{array}{l}\text { Findings of this paper showed that there was } \\
\text { the significant, direct and positive impact on } \\
\text { relationship between CSR, competitive } \\
\text { success and mediating effect of performance. }\end{array}$ \\
\hline Ağan et al. [164] & $\begin{array}{l}\text { Manufacturing } \\
\text { firms }\end{array}$ & 314 & Managers & None & $\begin{array}{l}\text { CSR to Environment, CSR to } \\
\text { Media, CSR to Employees, CSR to } \\
\text { Customers, Partnership with } \\
\text { NGOs, Supplier Evaluation, } \\
\text { Incentives, Direct Involvement, } \\
\text { Financial Performance and } \\
\text { Competitive Advantage. }\end{array}$ & $\begin{array}{l}\text { The main objective of this } \\
\text { paper is to examine the } \\
\text { relationship between CSR, } \\
\text { firm performance and } \\
\text { environmental supplier } \\
\text { development. }\end{array}$ & $\begin{array}{l}\text { There is a limitation of } \\
\text { literature regarding } \\
\text { environmental supplier } \\
\text { development. }\end{array}$ & $\begin{array}{l}\text { The findings of this study demonstrated that } \\
\text { CSR is positively related to environmental } \\
\text { supplier development and that } \\
\text { environmental supplier development had the } \\
\text { positive relationship between competitive } \\
\text { advantage of the participating firms and } \\
\text { financial performance. }\end{array}$ \\
\hline Zhu and Zhang [168] & $\begin{array}{l}\text { Manufacturing } \\
\text { industry }\end{array}$ & 146 & Senior manages & $\begin{array}{l}\text { Institutional } \\
\text { theory }\end{array}$ & $\begin{array}{l}\text { Community involvement and } \\
\text { development, charity-related CSR, } \\
\text { fair operating practices, consumer } \\
\text { issues, labor practices, employee } \\
\text { rights, competitive, coercive and } \\
\text { normative. }\end{array}$ & $\begin{array}{l}\text { The main goal of this } \\
\text { paper is to evaluate the } \\
\text { drivers and practices of } \\
\text { CSR. }\end{array}$ & $\begin{array}{l}\text { Need to evaluate the } \\
\text { drivers and practices of } \\
\text { CSR in developing } \\
\text { countries. }\end{array}$ & $\begin{array}{l}\text { The results of this paper indicated that high } \\
\text { internal CSR value enhances most CSR } \\
\text { practices, mimetic, coercive, normative and } \\
\text { coercive drivers motivate CSR practices. }\end{array}$ \\
\hline Laguir et al. [169] & Public firms & 83 & Managers & Agency theory & $\begin{array}{l}\text { CSR social dimension, CSR } \\
\text { governance dimension, economic } \\
\text { dimension and environmental } \\
\text { dimension. }\end{array}$ & $\begin{array}{l}\text { The main objective of this } \\
\text { paper is to examine the } \\
\text { different activities of CSR } \\
\text { influence on corporate tax } \\
\text { aggressiveness. }\end{array}$ & $\begin{array}{l}\text { In previous studies, } \\
\text { comparatively little } \\
\text { attention has been paid to } \\
\text { the link between CSR and } \\
\text { corporate tax } \\
\text { aggressiveness. }\end{array}$ & $\begin{array}{l}\text { Results of this study demonstrated that social } \\
\text { dimension of CSR had a negative relationship } \\
\text { with tax aggressiveness, and economic } \\
\text { dimension of CSR impact on tax } \\
\text { aggressiveness positively. }\end{array}$ \\
\hline Reverte et al. [163] & $\begin{array}{l}\text { Manufacturing and } \\
\text { non-manufacturing }\end{array}$ & 133 & Managers & $\begin{array}{l}\text { Theory of } \\
\text { Resources and } \\
\text { Capabilities }\end{array}$ & $\begin{array}{l}\text { Social dimension of CSR, economic } \\
\text { dimension of CSR, environmental } \\
\text { dimension of CSR, innovation, } \\
\text { financial performance and } \\
\text { non-financial performance. }\end{array}$ & $\begin{array}{l}\text { The main purpose of this } \\
\text { paper is to analyze the } \\
\text { relationship between CSR } \\
\text { and organizational } \\
\text { performance by mediating } \\
\text { impact of innovation. }\end{array}$ & $\begin{array}{l}\text { There is a lack in previous } \\
\text { studies regarding } \\
\text { non-financial performance } \\
\text { and innovation in } \\
\text { relationship of CRS and } \\
\text { performance. }\end{array}$ & $\begin{array}{l}\text { Results of this article found that there was the } \\
\text { significant and positive relationship between } \\
\text { CR, innovation and organizational } \\
\text { performance. }\end{array}$ \\
\hline $\begin{array}{l}\text { González-Rodríguez } \\
\text { et al. [170] }\end{array}$ & University & 1600 & Students & $\begin{array}{l}\text { Schwartz's human } \\
\text { values theory }\end{array}$ & $\begin{array}{l}\text { Self-transcendence, conservation, } \\
\text { self-enhancement and openness to } \\
\text { change. }\end{array}$ & $\begin{array}{l}\text { The main aim of this paper } \\
\text { is to develop drivers that } \\
\text { influence consumers and } \\
\text { entrepreneurs' perception } \\
\text { of corporate social } \\
\text { responsibility. }\end{array}$ & $\begin{array}{l}\text { There is a need to } \\
\text { determine the negative } \\
\text { factors which are related } \\
\text { to corporate image may to } \\
\text { have a negative } \\
\text { impression and perception, } \\
\text { and thus influence their } \\
\text { behavior. }\end{array}$ & $\begin{array}{l}\text { Results of this study found that human } \\
\text { values impact on humann perceptions of } \\
\text { corporate social responsibility, consumer } \\
\text { perceptions of corporate social responsibility } \\
\text { mediate the relationship between } \\
\text { entrepreneurs' perceptions of CSR and } \\
\text { human values and significant differences can } \\
\text { be found in consumers' and entrepreneurs' } \\
\text { perceptions of CSR with respect to the } \\
\text { cultural environment. }\end{array}$ \\
\hline
\end{tabular}


Table A3. Breakdown of articles based on renewable and sustainable energies.

\begin{tabular}{|c|c|c|c|c|c|c|c|c|}
\hline Author(s) Year & Scope and Sample & Sample Size & Respondents & Related Theory & Variables & Study Purpose & Gap and Research Problem & Results and Outcome \\
\hline $\begin{array}{l}\text { Seetharaman } \\
\text { et al. [173] }\end{array}$ & Energy industry & 106 & $\begin{array}{l}\text { People related to } \\
\text { energy in industry } \\
\text { such as managers }\end{array}$ & - & $\begin{array}{l}\text { Environmental Concerns, } \\
\text { Inadequate Customer } \\
\text { Relationships, Technology } \\
\text { Innovation Deficiencies, } \\
\text { Unstructured Business Process, } \\
\text { Lack of Societal Awareness, } \\
\text { Performance Instability, Regulatory } \\
\text { Policy Issues, Complex Operation, } \\
\text { Economically Unsustainable, } \\
\text { Business and Technology Strategies } \\
\text { Unaligned, Talent Shortage }\end{array}$ & $\begin{array}{l}\text { Investigated the relationship } \\
\text { between internal and } \\
\text { external forces on renewable } \\
\text { energy business. }\end{array}$ & $\begin{array}{l}\text { There is a need for more focus } \\
\text { on renewable energy market to } \\
\text { achieve more competitive } \\
\text { advantage. }\end{array}$ & $\begin{array}{l}\text { Results of this paper found that there is negative } \\
\text { direct effect between External Forces and Renewable } \\
\text { Energy and Positive Indirect Effect between internal } \\
\text { Forces and Renewable Energy and Positive Direct } \\
\text { Effect between External Forces and Internal Forces. }\end{array}$ \\
\hline Huang, Lo [175] & $\begin{array}{l}\text { Wind power } \\
\text { industry }\end{array}$ & 100 & Dataset & - & $\begin{array}{l}\text { Policy construct, social construct, } \\
\text { technical construct, environmental } \\
\text { construct, economic construct }\end{array}$ & $\begin{array}{l}\text { Used SEM and fuzzy } \\
\text { cognitive map for identify } \\
\text { the limitations regarding to } \\
\text { wind power development. }\end{array}$ & $\begin{array}{l}\text { There is a lack in previous } \\
\text { studies regarding the } \\
\text { correlation between the factors } \\
\text { which impact on development } \\
\text { of wind power. }\end{array}$ & $\begin{array}{l}\text { Findings of this paper showed that policy barriers can } \\
\text { be as the main challenge in development of wind } \\
\text { power and other obstructions. }\end{array}$ \\
\hline $\begin{array}{l}\text { Böttcher and } \\
\text { Müller [174] }\end{array}$ & $\begin{array}{l}\text { German automotive } \\
\text { suppliers }\end{array}$ & 108 & Manager & None & $\begin{array}{l}\text { Energy management system, low } \\
\text { carbon production, low carbon } \\
\text { logistics, carbon performance and } \\
\text { economic performance. }\end{array}$ & $\begin{array}{l}\text { The main goal of this study } \\
\text { is to examine the influence of } \\
\text { energy management systems } \\
\text { on manufacturing firms' } \\
\text { operation practices, } \\
\text { economic and carbon } \\
\text { performance. }\end{array}$ & $\begin{array}{l}\text { Need to place an emphasis on } \\
\text { energy management systems } \\
\text { in relationship among } \\
\text { manufacturing firms operation } \\
\text { practices, economic and carbon } \\
\text { performance. }\end{array}$ & $\begin{array}{l}\text { The findings of this paper demonstrated that energy } \\
\text { management had a positive impact on the adoption of } \\
\text { logistics practices and low carbon production and an } \\
\text { indirect relationship on economic and carbon } \\
\text { performance, and there was no direct relationship } \\
\text { between energy management system and carbon } \\
\text { performance. }\end{array}$ \\
\hline $\begin{array}{l}\text { Khorasanizadeh } \\
\text { et al. [178] }\end{array}$ & Residents & 221 & Citizens & $\begin{array}{l}\text { Unified Theory of } \\
\text { Acceptance and } \\
\text { Use of Technology }\end{array}$ & $\begin{array}{l}\text { Performance expectancy, effort } \\
\text { expectancy, social influence, } \\
\text { facilititating conditions, behavioral } \\
\text { intention and purchase decision. }\end{array}$ & $\begin{array}{l}\text { The main goal of this paper } \\
\text { is to investigate important } \\
\text { factors which play } \\
\text { significicant roles in successful } \\
\text { adoption of light-emitting } \\
\text { diodes-based lighting in } \\
\text { Malaysia. }\end{array}$ & $\begin{array}{l}\text { Few previous studies focused } \\
\text { on adoption of new } \\
\text { energy-efficient technologies } \\
\text { which decrease of ongoing } \\
\text { damage to the environment. }\end{array}$ & $\begin{array}{l}\text { The results confirmed that, Effort expectancy; } \\
\text { Performance expectancy, Facilitating conditions Social } \\
\text { influence and Behavioral intention were the main } \\
\text { factors in adoption of light emitting diodes-based } \\
\text { lighting. }\end{array}$ \\
\hline Chou et al. [176] & $\begin{array}{l}\text { Residential } \\
\text { buildings }\end{array}$ & 270 & Consumers & $\begin{array}{l}\text { Unified theory of } \\
\text { acceptance and } \\
\text { use of technology } \\
\text { (UTAUT), TAM } \\
\text { and Innovation } \\
\text { Diffusion Theory } \\
\text { (IDT) }\end{array}$ & $\begin{array}{l}\text { Behavioral intention to use, } \\
\text { attitude towards behavior, } \\
\text { perceived expected usefulness, } \\
\text { perceived expected ease of use, } \\
\text { perceived risk, user expected } \\
\text { satisfaction, social } \\
\text { influence/ norms, program } \\
\text { contents/features, technological } \\
\text { complexity, privacy/safety concern } \\
\text { and energy tariff/cost. }\end{array}$ & $\begin{array}{l}\text { The main goal of this paper } \\
\text { is to examine the differences } \\
\text { and similarities in consumer } \\
\text { adoption regarding the } \\
\text { understanding of smart } \\
\text { meters across. }\end{array}$ & $\begin{array}{l}\text { Need for an understanding of } \\
\text { consumer perception, } \\
\text { intention and expectation } \\
\text { regarding affect smart meter } \\
\text { adoption behavior. }\end{array}$ & $\begin{array}{l}\text { Results of this paper found that usefulness perception } \\
\text { of consumers,',risks of smart meters and aese of use } \\
\text { influenced consumer acceptance in Taiwan, Korea } \\
\text { and Indonesia, privacy and safety were not the main } \\
\text { concerns for Taiwan consumers, in Vietnam perceived } \\
\text { risk had no significant relationship with consumer } \\
\text { adoption of smart meters. }\end{array}$ \\
\hline $\begin{array}{c}\text { Lin and } \\
\text { Syrgabayeva [179] }\end{array}$ & Consumers & 45 & Consumers & $\begin{array}{l}\text { Theory of reason } \\
\text { action }\end{array}$ & $\begin{array}{l}\text { Knowledge about renewable } \\
\text { energy, environmental concern, } \\
\text { environmental belief, attitude } \\
\text { toward renewable energy and } \\
\text { willingness to pay more for } \\
\text { renewable energy. }\end{array}$ & $\begin{array}{l}\text { The main purpose of this } \\
\text { paper is to examine the } \\
\text { knowledge mechanism of } \\
\text { consumers on the intention } \\
\text { pay more for renewable } \\
\text { energy. }\end{array}$ & $\begin{array}{l}\text { Need to develop renewable } \\
\text { energy regarding } \\
\text { environmental concern in } \\
\text { developing countries. }\end{array}$ & $\begin{array}{l}\text { Results of this study found that concerns of } \\
\text { consumers regarding renewable energy had a positive } \\
\text { influence on attitudes and improving their } \\
\text { environmental beliefs and increasing their willingness } \\
\text { to pay more for renewable energy. }\end{array}$ \\
\hline $\begin{array}{l}\text { Böttcher and } \\
\text { Müller [177] }\end{array}$ & $\begin{array}{l}\text { Automotive } \\
\text { suppliers }\end{array}$ & 159 & Senior manager & None & $\begin{array}{l}\text { Stakeholder pressure, } \\
\text { competitiveness expectations, } \\
\text { low-carbon products, low-carbon } \\
\text { production, low-carbon logistics, } \\
\text { carbon performance and economic } \\
\text { performance. }\end{array}$ & $\begin{array}{l}\text { The aim of this paper is to } \\
\text { investigate the determinants } \\
\text { of measures used by German } \\
\text { auto-motive suppliers to cut } \\
\text { carbon emissions, and their } \\
\text { impact on performance. }\end{array}$ & $\begin{array}{l}\text { There are challenges and } \\
\text { opportunities in world } \\
\text { manufacturing companies to } \\
\text { measuring the reduce carbon } \\
\text { emissions. }\end{array}$ & $\begin{array}{l}\text { Results of this study found that there was a positive } \\
\text { impact on carbon and indirect impact on economic } \\
\text { performance. }\end{array}$ \\
\hline
\end{tabular}


Table A4. Breakdown of articles based on green and ecological innovation.

\begin{tabular}{|c|c|c|c|c|c|c|c|c|}
\hline $\begin{array}{l}\text { Author(s) } \\
\text { Year }\end{array}$ & Scope and Sample & Sample Size & Respondents & Related Theory & Variables & Study Purpose & Gap and Research Problem & Results and Outcome \\
\hline $\begin{array}{l}\text { Albort-Morant } \\
\text { et al. [189] }\end{array}$ & $\begin{array}{l}\text { Spanish automotive } \\
\text { components' } \\
\text { manufacturing } \\
\text { sector }\end{array}$ & 112 firms & Top executives & $\begin{array}{l}\text { Open innovation } \\
\text { theory }\end{array}$ & $\begin{array}{l}\text { Dynamic capabilities, Sensing } \\
\text { Capability, Learning Capability, } \\
\text { Integrating Capability, } \\
\text { Coordinating Capability, Green } \\
\text { Innovation Performance, } \\
\text { Relationship learning capabilities, } \\
\text { Information sharing capability, } \\
\text { Joint sense making capability and } \\
\text { Knowledge integration capability. }\end{array}$ & $\begin{array}{l}\text { The main purpose of this } \\
\text { paper is to examine the } \\
\text { relationship Dynamic } \\
\text { capabilities with green } \\
\text { innovation performance } \\
\text { with mediate effect of } \\
\text { Learning Capability. }\end{array}$ & $\begin{array}{l}\text { Few previous papers have } \\
\text { focused on the antecedents of } \\
\text { green innovation performance } \\
\text { such as different capabilities. }\end{array}$ & $\begin{array}{l}\text { Results of this paper found that there were } \\
\text { positive and significant direct and indirect effects } \\
\text { among capabilities on green innovation } \\
\text { performance. In addition; relationship learning } \\
\text { capabilities can mediate the relationship between } \\
\text { capabilities and green innovation performance. }\end{array}$ \\
\hline $\begin{array}{l}\text { Chan } \\
\text { et al. [191] }\end{array}$ & Industries in China & 250 & $\begin{array}{l}\text { Operations } \\
\text { managers }\end{array}$ & $\begin{array}{l}\text { Contingency } \\
\text { theory }\end{array}$ & $\begin{array}{l}\text { Pressure of environmental } \\
\text { regulations/policies, Green } \\
\text { product innovation, Cost efficiency, } \\
\text { Firm profitability and } \\
\text { Environmental dynamism }\end{array}$ & $\begin{array}{l}\text { The goal of this study is to } \\
\text { explore the influence of } \\
\text { green production } \\
\text { innovation on the } \\
\text { relationship between firm } \\
\text { performance and pressure } \\
\text { of environmental } \\
\text { regulations and } \\
\text { moderating impact of } \\
\text { environmental dynamism } \\
\text { on relationship od } \\
\text { performance and green } \\
\text { production innovation. }\end{array}$ & $\begin{array}{l}\text { There is a lack in the literature } \\
\text { regarding the mediating } \\
\text { influence of green product } \\
\text { innovation between firm and } \\
\text { pressure performance. }\end{array}$ & $\begin{array}{l}\text { The outcomes of this article found that there is a } \\
\text { positive relationship between pressure of } \\
\text { environmental regulations and green product } \\
\text { innovation, cost efficiency and firm profitability. } \\
\text { Also, there is a moderating effect of } \\
\text { environmental dynamism on the relationship of } \\
\text { green product innovation, firm profitability and } \\
\text { cost efficiency. }\end{array}$ \\
\hline $\begin{array}{l}\text { Zailani } \\
\text { et al. [183] }\end{array}$ & $\begin{array}{l}\text { Malaysian } \\
\text { automotive supply } \\
\text { chain industry }\end{array}$ & 153 & Managers & $\begin{array}{l}\text { Institutional } \\
\text { theory }\end{array}$ & $\begin{array}{l}\text { Environmental regulations, } \\
\text { marketing demand, firms' internal } \\
\text { initiatives, green product } \\
\text { innovation, green process } \\
\text { innovation, economic performance, } \\
\text { environmental performance and } \\
\text { social performance. }\end{array}$ & $\begin{array}{l}\text { The main goal of this } \\
\text { paper is to examine the } \\
\text { green innovation adoption } \\
\text { determinants its influence } \\
\text { on firm performance. }\end{array}$ & $\begin{array}{l}\text { Need to explore the GII } \\
\text { determinants for firms in the } \\
\text { automotive supply chain. }\end{array}$ & $\begin{array}{l}\text { Results of this paper found that market demand, } \\
\text { environmental regulations and firm internal } \\
\text { initiatives had the positive relationship with } \\
\text { green innovation initiatives, and GIIs had a } \\
\text { positive relationship with sustainable } \\
\text { performance. }\end{array}$ \\
\hline $\begin{array}{l}\text { Segarra-Oña } \\
\text { et al. [192] }\end{array}$ & $\begin{array}{l}\text { Manufacturing and } \\
\text { service firms }\end{array}$ & 6253 & Managers & $\begin{array}{l}\text { Absorptive } \\
\text { capacity theory }\end{array}$ & $\begin{array}{l}\text { Knowledge manufacturing, } \\
\text { operational manufacturing, } \\
\text { knowledge service and operational } \\
\text { service. }\end{array}$ & $\begin{array}{l}\text { The main goal of this } \\
\text { study is to examine the } \\
\text { sustainable innovations in } \\
\text { service and manufacturing } \\
\text { firms. }\end{array}$ & $\begin{array}{l}\text { There is a need to emphasize } \\
\text { innovation, knowledge and } \\
\text { sustainability to gain } \\
\text { competitive advantage. }\end{array}$ & $\begin{array}{l}\text { Findings of this paper showed that there was no } \\
\text { difference in the assimilate knowledge, firms } \\
\text { acquire and knowledge-intensive firms excel to } \\
\text { transform their ability to eco-innovate. }\end{array}$ \\
\hline $\begin{array}{l}\text { Chen } \\
\text { et al. [190] }\end{array}$ & $\begin{array}{l}\text { Taiwanese } \\
\text { manufacturing } \\
\text { industry }\end{array}$ & 3 & $\begin{array}{l}\text { CEOs or the } \\
\text { managers of } \\
\text { environmental, } \\
\text { marketing, HR, } \\
\text { manufacturing, or } \\
\text { R\&D departments }\end{array}$ & Grounded theory & $\begin{array}{l}\text { Environmental leadership, } \\
\text { environmental culture, } \\
\text { environmentac capability, the } \\
\text { pressure of the environmentalism } \\
\text { of investors and clients, the } \\
\text { pressure of environmental } \\
\text { regulations, proactive green } \\
\text { innovation and reactive green } \\
\text { innovation. }\end{array}$ & $\begin{array}{l}\text { The main objective of this } \\
\text { paper is to examine origins } \\
\text { two kinds of green } \\
\text { innovation including } \\
\text { reactive and proactive } \\
\text { innovations. }\end{array}$ & $\begin{array}{l}\text { Need to emphasize green } \\
\text { innovation as the important } \\
\text { tools for sustainable } \\
\text { development in } \\
\text { manufacturing industries. }\end{array}$ & $\begin{array}{l}\text { Findings of this paper showed that } \\
\text { environmental culture, environmental leadership, } \\
\text { environmental capability, the environmentalism } \\
\text { of investors and clients and environmental } \\
\text { regulations can generate green innovation. }\end{array}$ \\
\hline $\begin{array}{l}\text { Kam-Sing } \\
\text { Wong [193] }\end{array}$ & $\begin{array}{l}\text { Electronics firms } \\
\text { operating }\end{array}$ & 203 & $R \& D$ project leaders & $\begin{array}{l}\text { Green innovation } \\
\text { theory }\end{array}$ & $\begin{array}{l}\text { Green innovation, green product } \\
\text { innovation, green process } \\
\text { innovation, green product } \\
\text { competitive advantage and green } \\
\text { new product success. }\end{array}$ & $\begin{array}{l}\text { The main objective of this } \\
\text { paper is to examine the } \\
\text { impact of green product } \\
\text { innovation and product } \\
\text { process innovation on } \\
\text { green new product success } \\
\text { and product competitive } \\
\text { advantage. }\end{array}$ & $\begin{array}{l}\text { There is a gap in the literature } \\
\text { regarding green innovation } \\
\text { theory and concerning the } \\
\text { relationship among factors of } \\
\text { green innovation causal chain. }\end{array}$ & $\begin{array}{l}\text { Results of this paper demonstrated that process } \\
\text { innovation and green product had a positive } \\
\text { effect on green new product competitive } \\
\text { advantage and green new product success. }\end{array}$ \\
\hline
\end{tabular}


Table A4. Breakdown of articles based on green and ecological innovation.

\begin{tabular}{|c|c|c|c|c|c|c|c|c|}
\hline $\begin{array}{l}\text { Author(s) } \\
\text { Year }\end{array}$ & Scope and Sample & Sample Size & Respondents & Related Theory & Variables & Study Purpose & Gap and Research Problem & Results and Outcome \\
\hline $\begin{array}{l}\text { Abdullah } \\
\text { et al. [194] }\end{array}$ & $\begin{array}{l}\text { Manufacturing } \\
\text { companies }\end{array}$ & 153 & CEOs and managers & $\begin{array}{l}\text { Stakeholder } \\
\text { theory }\end{array}$ & $\begin{array}{l}\text { Environmental resources, } \\
\text { attitudinal and perception, } \\
\text { business practices, technical, poor } \\
\text { external partnership, insufficient } \\
\text { information, lack of government } \\
\text { support, lack of customer demand, } \\
\text { environmental commercial benefit, } \\
\text { product innovation, process } \\
\text { innovation and system innovation. }\end{array}$ & $\begin{array}{l}\text { The main objective of this } \\
\text { study is to explore the } \\
\text { external and internal } \\
\text { barriers to green } \\
\text { initiatives. }\end{array}$ & $\begin{array}{l}\text { There is a need to explore the } \\
\text { barriers of green innovation in } \\
\text { Malaysia's manufacturing } \\
\text { industry in the developing } \\
\text { phases and the significant } \\
\text { negative environmental } \\
\text { impacts. }\end{array}$ & $\begin{array}{l}\text { Findings of this paper showed that some barriers } \\
\text { such as green attitude and perception, insufficient } \\
\text { information, environmental commercial benefits } \\
\text { poor external partnerships, business practices and } \\
\text { lack of customer demand had a negative } \\
\text { relationship with green process innovations. }\end{array}$ \\
\hline $\begin{array}{l}\text { Segarra-Oña } \\
\text { et al. [195] }\end{array}$ & $\begin{array}{l}\text { Automotive } \\
\text { companies }\end{array}$ & 223 & Managers & None & $\begin{array}{l}\text { Market information sources, } \\
\text { process orientation, product } \\
\text { orientation and eco-orientation. }\end{array}$ & $\begin{array}{l}\text { The main findings of this } \\
\text { paper are the analysis of } \\
\text { the relationship between } \\
\text { market information } \\
\text { sources, process } \\
\text { orientation, product } \\
\text { orientation and } \\
\text { eco-orientation. }\end{array}$ & $\begin{array}{l}\text { Few previous studies have } \\
\text { been focused on the } \\
\text { eco-innovating in the } \\
\text { automobile industry. }\end{array}$ & $\begin{array}{l}\text { Results of this paper found that there was a } \\
\text { positive relationship between importance of } \\
\text { market information sources product and process } \\
\text { orientation, also there was a significant positive } \\
\text { relationship between product and process } \\
\text { orientation, and environmental orientation. }\end{array}$ \\
\hline $\begin{array}{l}\text { Chen and } \\
\text { Hung [196] }\end{array}$ & $\begin{array}{l}\text { Manufacturing } \\
\text { companies }\end{array}$ & 237 & Customers & $\begin{array}{l}\text { Social capital } \\
\text { theory }\end{array}$ & $\begin{array}{l}\text { Relational capital, structural } \\
\text { capital, cognitive capital, } \\
\text { knowledge sharing and innovation } \\
\text { performance. }\end{array}$ & $\begin{array}{l}\text { The main purpose of this } \\
\text { study is to explore the } \\
\text { relationship between } \\
\text { environmental } \\
\text { collaboration and green } \\
\text { innovation. }\end{array}$ & $\begin{array}{l}\text { There is a need for attention to } \\
\text { be paid to sustainability and } \\
\text { collaborative green innovation } \\
\text { in developing countries. }\end{array}$ & $\begin{array}{l}\text { Results of this study found that there was a } \\
\text { positive relationshiph between cognitive capital } \\
\text { and structural capital, cognitive capital and } \\
\text { relational capital, and relational capital was the } \\
\text { significant role in green management and } \\
\text { increased innovation. }\end{array}$ \\
\hline $\begin{array}{l}\text { Lin } \\
\text { et al. [197] }\end{array}$ & Vehicle industry & 233 & $\begin{array}{l}\text { Retailers, } \\
\text { wholesalers, and } \\
\text { firms selling } \\
\text { components }\end{array}$ & RBV theory & $\begin{array}{l}\text { Market demand, green innovation, } \\
\text { environmental performance and } \\
\text { firm performance. }\end{array}$ & $\begin{array}{l}\text { The main purpose of this } \\
\text { study is to investigate the } \\
\text { relationship between } \\
\text { market demand, firm } \\
\text { performance, } \\
\text { environmental } \\
\text { performance and green } \\
\text { innovation. }\end{array}$ & $\begin{array}{l}\text { There is a gap in the literature } \\
\text { regarding market demand, } \\
\text { green innovation, } \\
\text { environmental performance } \\
\text { and firm performance. }\end{array}$ & $\begin{array}{l}\text { Results of this paper found that there was a } \\
\text { significant relationship among all variables } \\
\text { expect for market demand and environmental } \\
\text { performance. }\end{array}$ \\
\hline $\begin{array}{l}\text { Pedersen } \\
\text { et al. [198] }\end{array}$ & $\begin{array}{l}\text { Swedish fashion } \\
\text { industry }\end{array}$ & 492 & Managers & $\begin{array}{l}\text { Stakeholder } \\
\text { theory }\end{array}$ & $\begin{array}{l}\text { Financial performance, business } \\
\text { model innovation, corporate } \\
\text { sustainability performance and } \\
\text { organizational values. }\end{array}$ & $\begin{array}{l}\text { The main purpose of this } \\
\text { article is to explore the } \\
\text { relationship financial } \\
\text { performance, business } \\
\text { model innovation, } \\
\text { corporate sustainability } \\
\text { performance and } \\
\text { organizational values. }\end{array}$ & $\begin{array}{l}\text { Few previous studies explore } \\
\text { how the dominant business } \\
\text { logic of the organization is } \\
\text { related to financial } \\
\text { performance and corporate } \\
\text { sustainability. }\end{array}$ & $\begin{array}{l}\text { Findings of this article indicated that companies } \\
\text { with innovative business models were related to } \\
\text { corporate sustainability, also there was a positive } \\
\text { relationship financial performance and } \\
\text { organizational values. }\end{array}$ \\
\hline
\end{tabular}

Table A5. Breakdown of articles based on green and sustainable HRM.

\begin{tabular}{|c|c|c|c|c|c|c|c|c|}
\hline Author(s) Year & Scope and Sample & Sample Size & Respondents & Related Theory & Variables & Study Purpose & Gap and Research Problem & Results and Outcome \\
\hline $\begin{array}{l}\text { Kalamas } \\
\text { et al. [204] }\end{array}$ & $\begin{array}{l}\text { Canadian urban } \\
\text { area }\end{array}$ & $\begin{array}{c}263 \\
\text { consumers }\end{array}$ & Consumers & $\begin{array}{l}\text { Theory of planned } \\
\text { behavior (TPB) }\end{array}$ & $\begin{array}{l}\text { Corporate responsibility, } \\
\text { Government responsibility, } \\
\text { God/higher power and Natural } \\
\text { earth-cycle }\end{array}$ & $\begin{array}{l}\text { This paper examines how } \\
\text { external attributions affect } \\
\text { pro-environmental } \\
\text { behaviors of consumers. }\end{array}$ & $\begin{array}{l}\text { Need to study the } \\
\text { understanding of consumers' } \\
\text { allocation regarding the } \\
\text { environmental responsibility } \\
\text { related to external forces. }\end{array}$ & $\begin{array}{l}\text { Results of this paper found that; analytical ways for } \\
\text { government and corporations to improve the } \\
\text { pro-environmental efforts. }\end{array}$ \\
\hline
\end{tabular}


Table A5. Breakdown of articles based on green and sustainable HRM.

\begin{tabular}{|c|c|c|c|c|c|c|c|c|}
\hline Author(s) Year & Scope and Sample & Sample Size & Respondents & Related Theory & Variables & Study Purpose & Gap and Research Problem & Results and Outcome \\
\hline Wan et al. [208] & $\begin{array}{l}\text { Four shopping malls } \\
\text { and two railway } \\
\text { stations }\end{array}$ & 246 people & Customers & $\begin{array}{c}\text { Theory of planned } \\
\text { behaviour }\end{array}$ & $\begin{array}{l}\text { Attitude, Subjective Norm, } \\
\text { Perceived Behavioural Control, } \\
\text { Moral Norm, Consequences } \\
\text { Awareness, Perceived Policy } \\
\text { Effectiveness and Behavioural } \\
\text { Intention. }\end{array}$ & $\begin{array}{l}\text { Investigated the } \\
\text { moderating effect of } \\
\text { perceived policy } \\
\text { effectiveness regarding to } \\
\text { recycling intention. }\end{array}$ & $\begin{array}{l}\text { Need to better understand the } \\
\text { recycling intention in Hong } \\
\text { Kong. }\end{array}$ & $\begin{array}{l}\text { Results of this study found that there are negative } \\
\text { relationships between the perceived policy } \\
\text { effectiveness between subjective norm and } \\
\text { reycling intention, also between recycling } \\
\text { intention and consequences awareness. }\end{array}$ \\
\hline Zhan et al. [205] & $\begin{array}{l}\text { Manufacturing } \\
\text { industry }\end{array}$ & $\begin{array}{l}172 \\
\text { respondents }\end{array}$ & Students & - & $\begin{array}{l}\text { Mindset and attitude, Leadership } \\
\text { and management, Employee } \\
\text { involvement, Integrated approach, } \\
\text { Tools and techniquese, Guanxi, } \\
\text { Environmental performance and } \\
\text { Business performance. }\end{array}$ & $\begin{array}{l}\text { Evaluated the relationship } \\
\text { between lean and green } \\
\text { practices and } \\
\text { organizational } \\
\text { performance by } \\
\text { moderation effect of } \\
\text { guanxi. }\end{array}$ & $\begin{array}{l}\text { Need to focus on the green and } \\
\text { lean practice to attain } \\
\text { sustainable development to } \\
\text { enhance organizational } \\
\text { performance in China context. }\end{array}$ & $\begin{array}{l}\text { Results of this study indicated that there was a } \\
\text { positive relationship between green and lean } \\
\text { practices and improve organizational performance. }\end{array}$ \\
\hline Chin et al. [209] & $\begin{array}{l}\text { oil palm smallholder } \\
\text { planters }\end{array}$ & 327 & smallholders & $\begin{array}{l}\text { Theory of Planned } \\
\text { Behaviour }\end{array}$ & $\begin{array}{l}\text { Perceived production benefit, } \\
\text { Perceived environmental benefit, } \\
\text { Perceived ecological impact, } \\
\text { Attitude, Subjective norm, } \\
\text { Perceived behavioural control and } \\
\text { Intention. }\end{array}$ & $\begin{array}{l}\text { Explore smallholder } \\
\text { planters' intention for } \\
\text { supply available residues } \\
\text { of oil palm in the } \\
\text { plantations based on TPB } \\
\text { theory. }\end{array}$ & $\begin{array}{l}\text { There is a lack of } \\
\text { understanding of planters } \\
\text { regarding supply oil palm } \\
\text { biomass in Malaysia. }\end{array}$ & $\begin{array}{l}\text { Findings of this paper showed that there is a } \\
\text { positive relationship among smallholder planters' } \\
\text { intention and perceived behavioural control, } \\
\text { subjective norm, attitude and perceived } \\
\text { environmental benefit and perceived production } \\
\text { benefit. }\end{array}$ \\
\hline $\begin{array}{l}\text { Wan and } \\
\text { Shen [206] }\end{array}$ & $\begin{array}{l}\text { Hong Kong } \\
\text { Telecommunications } \\
\text { Limited }\end{array}$ & 263 & $\begin{array}{l}\text { Hong Kong } \\
\text { residents }\end{array}$ & $\begin{array}{l}\text { Theory of planned } \\
\text { behaviour (TPB) }\end{array}$ & $\begin{array}{l}\text { Perceived provision of facilities, } \\
\text { Perceived naturalness, Perceived } \\
\text { accessibility, Attitude, Perceived } \\
\text { usefulness, Subjective norm, } \\
\text { Perceived behaviourac control, } \\
\text { Behavioural intention and } \\
\text { Behaviour. }\end{array}$ & $\begin{array}{l}\text { The objective of this article } \\
\text { is to find the relationships } \\
\text { between urban green } \\
\text { spaces attributes and } \\
\text { urban green space use } \\
\text { with mediating effect } \\
\text { perceived usefulness } \\
\text { attitude, and perceived } \\
\text { behavioural control. }\end{array}$ & $\begin{array}{l}\text { There is a lack in previous } \\
\text { studies regarding urban green } \\
\text { space which did not consider } \\
\text { the three factors including } \\
\text { perceived usefulness attitude, } \\
\text { and perceived behavioural } \\
\text { control. }\end{array}$ & $\begin{array}{l}\text { The findings of this article showed that perceived } \\
\text { usefulness attitude, and perceived behavioural } \\
\text { control have a mediating effect in relationship } \\
\text { between the behavioural intention to use urban } \\
\text { green space. In addition; urbang green space does } \\
\text { not iffluence behaviour indirectly with attitude } \\
\text { factors and perceived behavioural control. }\end{array}$ \\
\hline Chiu et al. [210] & $\begin{array}{l}\text { Ecological zones of } \\
\text { the island }\end{array}$ & 328 & Tourists & $\begin{array}{l}\text { Value-attitude-behav } \\
\text { theory }\end{array}$ & $\begin{array}{l}\text { Environmentally responsible } \\
\text { iorohavior, Perceived value, Activity } \\
\text { involvement and Satisfaction. }\end{array}$ & $\begin{array}{l}\text { Investigated the } \\
\text { antecedents of tourist } \\
\text { behaviour for outline of } \\
\text { environmentally } \\
\text { responsible behavior. }\end{array}$ & $\begin{array}{l}\text { Need to explore the level of } \\
\text { environmentally responsible } \\
\text { behavior which can change } \\
\text { results of eco-travel } \\
\text { experience. }\end{array}$ & $\begin{array}{l}\text { Findings of this paper showed that activity } \\
\text { involvement, satisfaction and perceived value can } \\
\text { encourage tourist environmentally responsible } \\
\text { behavior and perceived value can influence } \\
\text { environmentally responsible behavior directly, } \\
\text { while involvememen and satisfaction had partial } \\
\text { mediation. }\end{array}$ \\
\hline Zhang et al. [211] & $\begin{array}{l}\text { Industrial } \\
\text { Manufacturing } \\
\text { firms }\end{array}$ & 187 & Vice-president & $\begin{array}{l}\text { Institutional } \\
\text { theory (INT) }\end{array}$ & $\begin{array}{l}\text { Energy conservation strategy, } \\
\text { Concrete operations for energy } \\
\text { conservation, Environmental } \\
\text { concern of senior manager, } \\
\text { Coercive pressure, Normative } \\
\text { pressure, Mimetic pressure and } \\
\text { Financial cost. }\end{array}$ & $\begin{array}{l}\text { The main aim of this paper } \\
\text { is to examine the } \\
\text { relationship between } \\
\text { practices of firm energy } \\
\text { conservation and external } \\
\text { pressure with moderating } \\
\text { effect of managers' } \\
\text { environmental concerns. }\end{array}$ & $\begin{array}{l}\text { There is a need to examine } \\
\text { how environmental managers' } \\
\text { concern can influence external } \\
\text { pressure and an organizations } \\
\text { environmental practices. }\end{array}$ & $\begin{array}{l}\text { Findings of this study showed that senior } \\
\text { manager's environmental concerns had a } \\
\text { significant role in between firms' energy saving } \\
\text { factors and the external pressures like mimetic and } \\
\text { normative pressures. Although the senior } \\
\text { manager's environmental concerns had a positive } \\
\text { effect on the energy conservation strategy there was } \\
\text { no direct effect on the concrete operations of energy } \\
\text { conservation. }\end{array}$ \\
\hline $\begin{array}{l}\text { Ramayah } \\
\text { et al. [212] }\end{array}$ & University & 200 & Students & $\begin{array}{l}\text { Theory of Planned } \\
\text { Behaviour (TPB) }\end{array}$ & $\begin{array}{l}\text { Environment awareness cost of } \\
\text { recycling, attitude, convenience, } \\
\text { recycling behaviour and subjective } \\
\text { norm. }\end{array}$ & $\begin{array}{l}\text { The main goal of this } \\
\text { paper is to investigate the } \\
\text { recycling behaviour } \\
\text { determinations in } \\
\text { Malaysia. }\end{array}$ & $\begin{array}{l}\text { Due to lifestyle in the Malaysia } \\
\text { urban area there are some } \\
\text { waste problems which need to } \\
\text { be considered. }\end{array}$ & $\begin{array}{l}\text { Results of this study found that environmental } \\
\text { awareness had a significant relationship to attitude } \\
\text { towards reccycling and attitude and social norms } \\
\text { had the significant relationship with recycling } \\
\text { behaviour and finally cost of recycling and } \\
\text { convenience were not significant reasons for } \\
\text { recycling. }\end{array}$ \\
\hline
\end{tabular}


Table A5. Breakdown of articles based on green and sustainable HRM.

\begin{tabular}{|c|c|c|c|c|c|c|c|c|}
\hline Author(s) Year & Scope and Sample & Sample Size & Respondents & Related Theory & Variables & Study Purpose & Gap and Research Problem & Results and Outcome \\
\hline $\begin{array}{l}\text { Zareie and Jafari } \\
\text { Navimipour [213] }\end{array}$ & University & 330 & Students & $\begin{array}{l}\text { Theory of } \\
\text { reasoned action } \\
\text { (TRA) }\end{array}$ & $\begin{array}{l}\text { Environmental attitudes, } \\
\text { environmental awareness, } \\
\text { environmental values, public } \\
\text { information, environmental skills } \\
\text { and environmental responsibility. }\end{array}$ & $\begin{array}{l}\text { The main objective of this } \\
\text { paper to examine the } \\
\text { influence of The electronic } \\
\text { environmental knowledge } \\
\text { on the people } \\
\text { environmental behaviors. }\end{array}$ & $\begin{array}{l}\text { There is lack in previous } \\
\text { papers regarding the main } \\
\text { shortcomings in the issues of } \\
\text { public understanding and } \\
\text { environmental awareness. }\end{array}$ & $\begin{array}{l}\text { Findings of this paper found that; there are positive } \\
\text { relationship between environmental attitudes, } \\
\text { environmental awareness, environmental values, } \\
\text { public information, environmental skills, } \\
\text { environmental responsibility and environmental } \\
\text { behaviors. }\end{array}$ \\
\hline Wan et al. [207] & $\begin{array}{l}\text { Four shopping } \\
\text { malls, Two railway } \\
\text { stations }\end{array}$ & 198 & Customers & $\begin{array}{l}\text { Theory of Planned } \\
\text { Behaviour (TPB) }\end{array}$ & $\begin{array}{l}\text { Attitude, Subjective norm, } \\
\text { Perceived behavioural control, } \\
\text { Moral norm, Consequences } \\
\text { awareness, Perceived policy } \\
\text { effectiveness, Behavioural } \\
\text { intention, Direct behaviour, } \\
\text { Indirect behaviour }\end{array}$ & $\begin{array}{l}\text { The main goal of this } \\
\text { paper to developed the } \\
\text { new model of recycling } \\
\text { attitude and behaviour for } \\
\text { finding the relationship } \\
\text { between recycling } \\
\text { behaviour and perceived } \\
\text { policy effectiveness. }\end{array}$ & $\begin{array}{l}\text { Few studies focused on the } \\
\text { relationship between TPB and } \\
\text { NAM and recycling intentions. }\end{array}$ & $\begin{array}{l}\text { Results of this paper demonstrated that, recycling } \\
\text { intention is affected by moral norms, perceived } \\
\text { behavioural control, subjective norms, awareness of } \\
\text { consequences and perceived policy effectiveness. } \\
\text { Also self-reported recycling behaviour and support } \\
\text { had influence by recycling intention. }\end{array}$ \\
\hline $\begin{array}{l}\text { Jiménez-Parra } \\
\text { et al. [214] }\end{array}$ & $\begin{array}{l}\text { Two Spanish } \\
\text { universities }\end{array}$ & 1529 & Students & $\begin{array}{c}\text { Theory of Planned } \\
\text { Behavior }\end{array}$ & $\begin{array}{l}\text { Attitude towards purchasing a } \\
\text { remanufactured laptop, Subjective } \\
\text { Norm, Motivations, Marketing Mix } \\
\text { Variables and Purchase Intention. }\end{array}$ & $\begin{array}{l}\text { The main objective of this } \\
\text { study is to explore the } \\
\text { main key drivers in the } \\
\text { consumers' behavior } \\
\text { related to remanufactured } \\
\text { products. }\end{array}$ & $\begin{array}{l}\text { There is a lack of literature } \\
\text { review regarding the market } \\
\text { for products recovery, } \\
\text { consumers' acceptance, } \\
\text { markets promotions, } \\
\text { marketing strategies. }\end{array}$ & $\begin{array}{l}\text { Findings of this paper showed that consumers had } \\
\text { a favorable attitude towards in remanufacturing } \\
\text { products, respect for clean environment, and a } \\
\text { positive consideration of the opinion of their close } \\
\text { social environment when making a purchase. }\end{array}$ \\
\hline $\begin{array}{l}\text { Larrán Jorge } \\
\text { et al. [215] }\end{array}$ & SME's & 481 & $\begin{array}{l}\text { Managers or middle } \\
\text { managers }\end{array}$ & $\begin{array}{l}\text { Theory of } \\
\text { resources and } \\
\text { capabilities }\end{array}$ & $\begin{array}{l}\text { Environmental performance, } \\
\text { competitive performance, image } \\
\text { and reputation. }\end{array}$ & $\begin{array}{l}\text { The main goal of this } \\
\text { study is to analyze the } \\
\text { environmental } \\
\text { performance and } \\
\text { environmental } \\
\text { competitive. }\end{array}$ & $\begin{array}{l}\text { There is a lack in previous } \\
\text { studies regarding } \\
\text { environmental performance } \\
\text { and environmental } \\
\text { competitive. }\end{array}$ & $\begin{array}{l}\text { The findings of this paper showed that } \\
\text { environmental performance had a significant, direct } \\
\text { and positive impact on competitive performance } \\
\text { and mediating effects of rational and image } \\
\text { marketing. }\end{array}$ \\
\hline Yusof et al. [216] & $\begin{array}{l}\text { Architectural, } \\
\text { engineering, and } \\
\text { contracting firms }\end{array}$ & 375 & Board & None & $\begin{array}{l}\text { Energy efficiency, Waste } \\
\text { management, Involvement, Project } \\
\text { environmental behaviour. }\end{array}$ & $\begin{array}{l}\text { The main purpose of this } \\
\text { study is to examine, the } \\
\text { relationship between } \\
\text { environmental and the } \\
\text { environmental behaviour } \\
\text { of professionals. }\end{array}$ & $\begin{array}{l}\text { Need to consider energy } \\
\text { consumption and reduction of } \\
\text { waste generation in } \\
\text { construction projects. }\end{array}$ & $\begin{array}{l}\text { Results of this paper found that waste management } \\
\text { practices and energy efficiency had a positive } \\
\text { relationship with the environmental behaviour of } \\
\text { practitioners during project implementation. }\end{array}$ \\
\hline $\begin{array}{l}\text { Wang and } \\
\text { Wu [217] }\end{array}$ & Residents & 775 & Households & Theory of emotion & $\begin{array}{l}\text { Pride, Respect, Guilt, Anger, } \\
\text { intention of resisting non-energy } \\
\text { conserving household appliances, } \\
\text { intention of purchasing energy } \\
\text { conserving household appliances; } \\
\text { switch regular brand specialize in } \\
\text { purchasing and pay more money. }\end{array}$ & $\begin{array}{l}\text { The purpose of this paper } \\
\text { is to examine the influence } \\
\text { of respect, guilt, anger and } \\
\text { anger on consumers' } \\
\text { intention of sustainable } \\
\text { consumption choice of } \\
\text { household appliances. }\end{array}$ & $\begin{array}{l}\text { Few previous studies have } \\
\text { emphasized the influence of } \\
\text { different emotions on specific } \\
\text { sustainable consumption } \\
\text { behavior. }\end{array}$ & $\begin{array}{l}\text { Findings of this paper showed that there was a } \\
\text { positive relationship between guilt, pride and } \\
\text { purchasing energy conserving household } \\
\text { appliances and resisting non-energy conserving } \\
\text { household appliances, anger only has a positive } \\
\text { relationship with the latter and pride had a } \\
\text { significant relationship with four emotions and } \\
\text { resistance behavior mediated the influence on guilt, } \\
\text { pride and respect on the purchase behavior. }\end{array}$ \\
\hline $\begin{array}{l}\text { Carmona-Moreno } \\
\text { et al. [218] }\end{array}$ & $\begin{array}{l}\text { Spanish chemical } \\
\text { firms }\end{array}$ & 94 & $\mathrm{CEOs}$ & $\begin{array}{l}\text { Institutional } \\
\text { theory }\end{array}$ & $\begin{array}{l}\text { Pollution prevention, } \\
\text { environmental human resource } \\
\text { management, competitive } \\
\text { advantage in costs and competitive } \\
\text { advantage in differentiation. }\end{array}$ & $\begin{array}{l}\text { The main goal of this } \\
\text { paper is to explore the } \\
\text { moderating influence of } \\
\text { environmental HRM on } \\
\text { relationship between } \\
\text { competitive advantages of } \\
\text { cost and firms' } \\
\text { environmental } \\
\text { management practices. }\end{array}$ & $\begin{array}{l}\text { There is need to emphasize the } \\
\text { role of environmental HRM for } \\
\text { increase economic } \\
\text { performance by involving of } \\
\text { pollution prevention } \\
\text { technologies. }\end{array}$ & $\begin{array}{l}\text { Findings of this study showed that firms which } \\
\text { focused more on environmental } \mathrm{HRM} \text { practices get } \\
\text { more advantage in costs and differentiation derived } \\
\text { from the pollution prevention technologies } \\
\text { implementation. }\end{array}$ \\
\hline
\end{tabular}


Table A5. Breakdown of articles based on green and sustainable HRM.

\begin{tabular}{|c|c|c|c|c|c|c|c|c|}
\hline Author(s) Year & Scope and Sample & Sample Size & Respondents & Related Theory & Variables & Study Purpose & Gap and Research Problem & Results and Outcome \\
\hline Wan et al. [219] & University & 205 & Students and Staffs & $\begin{array}{l}\text { Theory of planned } \\
\text { behaviour }\end{array}$ & $\begin{array}{l}\text { Attitude, subjective norms, } \\
\text { perceived behavioural control, } \\
\text { awareness of consequences, moral } \\
\text { norm, convenience and recycling } \\
\text { intention. }\end{array}$ & $\begin{array}{l}\text { The main purpose of this } \\
\text { study is to investigate the } \\
\text { role of recycling attitudes } \\
\text { and behaviour of } \\
\text { university students and } \\
\text { staff members for } \\
\text { enhancing environmental } \\
\text { policies and recycling } \\
\text { facilities in the university } \\
\text { campus. }\end{array}$ & $\begin{array}{l}\text { Need to emphasize } \\
\text { user-friendly and convenient } \\
\text { recycling scheme in } \\
\text { universities. }\end{array}$ & $\begin{array}{l}\text { Results of this paper found that behavioural } \\
\text { intention with regard to recycling affected by the } \\
\text { subjective norms, convenience, awareness of } \\
\text { consequences, attitude, perceived behavioural } \\
\text { control and the moral norms. }\end{array}$ \\
\hline $\begin{array}{l}\text { Tien-Shang } \\
\text { Lee [220] }\end{array}$ & Largest firms & 195 & Managers & $\begin{array}{l}\text { Stakeholder and } \\
\text { CSR theories }\end{array}$ & $\begin{array}{l}\text { Instrumental motives, political } \\
\text { motives, corporate environmental } \\
\text { responsibility, environmental } \\
\text { product policy and environmental } \\
\text { performance. }\end{array}$ & $\begin{array}{l}\text { The main aim of this } \\
\text { article is to analyze the } \\
\text { relationship of corporate } \\
\text { motivation, environmental } \\
\text { responsibility, } \\
\text { environmental } \\
\text { performance and the } \\
\text { adoption of environmental } \\
\text { product policies. }\end{array}$ & $\begin{array}{l}\text { Need to emphasize } \\
\text { environmental responsibility } \\
\text { in various business } \\
\text { environments regarding the } \\
\text { implementation of an } \\
\text { environmentally oriented } \\
\text { policy. }\end{array}$ & $\begin{array}{l}\text { Findings of this paper showed that environmental } \\
\text { performance had a direct relationship with politital } \\
\text { motives and instrumental motives, and indirect } \\
\text { influence on environmental performance, } \\
\text { instrumental motives had a marginal impact on } \\
\text { environmental performance and environmental } \\
\text { responsibility, and a marginal impact of political } \\
\text { motives on environmental performance. }\end{array}$ \\
\hline Kim et al. [221] & Restaurants chain & 413 & $\begin{array}{l}\text { Seniors and } \\
\text { non-seniors }\end{array}$ & None & $\begin{array}{l}\text { Environmentalism, green } \\
\text { consumerism, conserving } \\
\text { resources, trust, healthy food } \\
\text { choices and emotional loyalty. }\end{array}$ & $\begin{array}{l}\text { The main aim of this paper } \\
\text { is to examine the } \\
\text { relationship between } \\
\text { sustainability, lifestyle of } \\
\text { health, trust, healthy food } \\
\text { choices and emotional } \\
\text { loyalty and moderating } \\
\text { role of between } \\
\text { non-seniors and seniors in } \\
\text { restaurants. }\end{array}$ & $\begin{array}{l}\text { Need to focus on sustainability, } \\
\text { lifestyle of health, trust, } \\
\text { heaethy food choices and } \\
\text { emotional loyalty and } \\
\text { moderating role of between } \\
\text { non-seniors and seniors in } \\
\text { restaurants. }\end{array}$ & $\begin{array}{l}\text { Results of this paper indicated that the senior } \\
\text { market segment is different from the non-senior } \\
\text { makrest segment. The influence of lifestestle, health } \\
\text { and sustainability on healthy food choices is } \\
\text { stronger for non-senior diners and the lifestyle of } \\
\text { health and sustainability on emotional loyalty and } \\
\text { trust for seniors and non-seniors. }\end{array}$ \\
\hline Paillé et al. [222] & $\begin{array}{l}\text { Manufacturing } \\
\text { firms }\end{array}$ & 151 & $\begin{array}{l}\text { Top management } \\
\text { team members, chief } \\
\text { executive officers, } \\
\text { and frontline } \\
\text { workers }\end{array}$ & $\begin{array}{l}\text { Stakeholder } \\
\text { theory }\end{array}$ & $\begin{array}{l}\text { Strategic human resource } \\
\text { management, organizational } \\
\text { citizenship behaviour toward } \\
\text { environment, internal } \\
\text { environmental orientation and } \\
\text { environmental performance. }\end{array}$ & $\begin{array}{l}\text { The main objective of this } \\
\text { study is to explore the } \\
\text { relationship between } \\
\text { strategic human resource } \\
\text { management, } \\
\text { organizational citizenship } \\
\text { behaviour toward } \\
\text { environment, internal } \\
\text { environmental orientation } \\
\text { and environmental } \\
\text { performance. }\end{array}$ & $\begin{array}{l}\text { Few previous published } \\
\text { studies have addressed the } \\
\text { role of strategic human } \\
\text { resource management, } \\
\text { organizational citizenship } \\
\text { behaviour toward } \\
\text { environment and internal } \\
\text { environmental orientation to } \\
\text { improve their environmental } \\
\text { performance. }\end{array}$ & $\begin{array}{l}\text { Findings of this paper showed that organizational } \\
\text { citizenship behavior had the full mediation of } \\
\text { relationshhip between environmental performance } \\
\text { and strategic human resource management also } \\
\text { that internal environmental had a moderate effect } \\
\text { on strategic human resource management and } \\
\text { organizational citizenship behavior. }\end{array}$ \\
\hline Ahmad et al. [223] & University & 230 & Students & $\begin{array}{l}\text { Theory of Planned } \\
\text { Behavior and The } \\
\text { Theory of } \\
\text { Reasoned action }\end{array}$ & $\begin{array}{l}\text { Attitude, moral norms, subjective } \\
\text { norms, convenience, recycling cost, } \\
\text { time and recycling behaviour. }\end{array}$ & $\begin{array}{l}\text { The main objective of this } \\
\text { paper is to explore } \\
\text { respondents' behaviors } \\
\text { regarding the recycling for } \\
\text { identification of the factors } \\
\text { which impact their } \\
\text { behaviors. }\end{array}$ & $\begin{array}{l}\text { Need to emphasize the } \\
\text { understanding of how } \\
\text { recycling behaviors are } \\
\text { determined by one's social } \\
\text { values, demeanor and } \\
\text { perception of recycling } \\
\text { behavior. }\end{array}$ & $\begin{array}{l}\text { Results of this paper found that there were positive } \\
\text { relationships between environmental awareness } \\
\text { and attitude, extent of knowledge regarding } \\
\text { recycling with attitude, extent of concerns for } \\
\text { community with attitude, previous recycling } \\
\text { behaviour with attitude, attitude with reycling } \\
\text { behaviour, social norms with recycling behaviour, } \\
\text { and morals norms with recycling behaviour. }\end{array}$ \\
\hline $\begin{array}{c}\text { Dögl and } \\
\text { Holtbrügge [224] }\end{array}$ & $\begin{array}{l}\text { Manufacturing and } \\
\text { service companies }\end{array}$ & 215 & $\begin{array}{l}\text { Managers and CER } \\
\text { experts }\end{array}$ & Signaling theory & $\begin{array}{l}\text { Green strategy \& culture, green } \\
\text { technology \& products, green } \\
\text { recruitment \& evaluation, } \\
\text { environmental reputation and } \\
\text { employee commitment. }\end{array}$ & $\begin{array}{l}\text { The main purpose of this } \\
\text { article is to examine the } \\
\text { relationshipip between } \\
\text { employee reputation, } \\
\text { corporate environmental } \\
\text { responsibility and } \\
\text { employee commitment. }\end{array}$ & $\begin{array}{l}\text { Little attentions has been paid } \\
\text { to the important role of } \\
\text { corporate environmental } \\
\text { responsibility for employer } \\
\text { attractiveness and employee } \\
\text { commitment. }\end{array}$ & $\begin{array}{l}\text { Results of this paper found that there are positive } \\
\text { relationship between environmental reputation, } \\
\text { green technology \& products, green strategy \& } \\
\text { culture, green communication and green } \\
\text { recruitment \& evaluation and in turn employee } \\
\text { commitment. }\end{array}$ \\
\hline
\end{tabular}


Table A5. Breakdown of articles based on green and sustainable HRM.

\begin{tabular}{|c|c|c|c|c|c|c|c|c|}
\hline Author(s) Year & Scope and Sample & Sample Size & Respondents & Related Theory & Variables & Study Purpose & Gap and Research Problem & Results and Outcome \\
\hline $\begin{array}{l}\text { Cegarra-Navarro } \\
\text { et al. [225] }\end{array}$ & $\begin{array}{l}\text { Pharmaceutical } \\
\text { industry }\end{array}$ & 225 & Seller & $\begin{array}{l}\text { Theory of green } \\
\text { committees }\end{array}$ & $\begin{array}{l}\text { Technical dimension, } \\
\text { administrative dimension, social } \\
\text { dimension, customer capital and } \\
\text { green communities. }\end{array}$ & $\begin{array}{l}\text { The main objective of this } \\
\text { study is to investigate the } \\
\text { relationship between } \\
\text { environmental } \\
\text { management, customer } \\
\text { capital and green } \\
\text { communities }\end{array}$ & $\begin{array}{l}\text { Little attention has been paid } \\
\text { to the relationship between } \\
\text { environmental management, } \\
\text { customer capital and green } \\
\text { communities }\end{array}$ & $\begin{array}{l}\text { Results of this paper found that customer capital } \\
\text { had a positive relationship with environmental } \\
\text { knowledge, also environmental knowledge impact } \\
\text { of customer capital with mediation with, customer } \\
\text { capital and green communities. }\end{array}$ \\
\hline Kim et al. [226] & Hotels & 172 & General managers & $\begin{array}{l}\mathrm{RBV} \text { and } \\
\text { institutional } \\
\text { theory }\end{array}$ & $\begin{array}{l}\text { General managers environmental } \\
\text { commitment, hotels' } \\
\text { environmental management } \\
\text { capabilities and hotels' } \\
\text { involvement in environmental } \\
\text { practices. }\end{array}$ & $\begin{array}{l}\text { The main purpose of this } \\
\text { study was to investigate } \\
\text { the relationship between } \\
\text { environmental } \\
\text { commitment of general } \\
\text { managers and } \\
\text { environmental } \\
\text { management capabilities } \\
\text { and involvement of hotel } \\
\text { in environmental } \\
\text { practices. }\end{array}$ & $\begin{array}{l}\text { Need for involvement of } \\
\text { individual people in hotels in } \\
\text { involvement of environmental } \\
\text { practices and understanding of } \\
\text { hotel managers regarding to } \\
\text { environmental management. }\end{array}$ & $\begin{array}{l}\text { Results of this study found that general managers' } \\
\text { environmental commitment influenced hotels' } \\
\text { involvement regarding environmental practices } \\
\text { directly and indirectly with involving } \\
\text { environmental capabilities. }\end{array}$ \\
\hline $\begin{array}{l}\text { Castellanos-Verdugo } \\
\text { et al. [227] }\end{array}$ & Tourism & 520 & Tourists & TPB & $\begin{array}{l}\text { Eco-tourist site perceived value, } \\
\text { ecotourism knowledge, attitudes } \\
\text { towards ecotourism, eco-tourist } \\
\text { satisfaction and behavioral } \\
\text { intentions. }\end{array}$ & $\begin{array}{l}\text { The main purpose of this } \\
\text { study is to explore the } \\
\text { relationship between } \\
\text { Eco-tourist site perceived } \\
\text { value, ecotourism } \\
\text { knowledge, attitudes } \\
\text { towards ecotourism, } \\
\text { eco-tourist satisfaction and } \\
\text { behavioral intentions. }\end{array}$ & $\begin{array}{l}\text { There is a lack in previous } \\
\text { literature regarding } \\
\text { ecotourism knowledge and } \\
\text { attitudes towards ecotourism. }\end{array}$ & $\begin{array}{l}\text { Results of this study show that there was a positive } \\
\text { relationship between ecotourism knowledge and } \\
\text { the perceived value of the eco-tourist site, the value } \\
\text { of the tourist site perceived by the touristimpact on } \\
\text { attitude of the tourist towards ecotourism, also the } \\
\text { perceived value of the tourist site impacts on the } \\
\text { satisfaction of the visitor and finally there was a } \\
\text { relationship between the satisfaction and the future } \\
\text { behavioral intention of the visitor. }\end{array}$ \\
\hline $\begin{array}{l}\text { Gonul Kochan } \\
\text { et al. [228] }\end{array}$ & University & 327 & Students & $\begin{array}{c}\text { Theory of } \\
\text { Reasoned Action }\end{array}$ & $\begin{array}{l}\text { Attitude toward e-cycling, } \\
\text { perceived norms, awareness of } \\
\text { consequences, perceived } \\
\text { convenience, e-cycling intention } \\
\text { and e-cycling behavior }\end{array}$ & $\begin{array}{l}\text { The main objective of this } \\
\text { study is to use the theory } \\
\text { of reasoned action for } \\
\text { identify of e-cycling } \\
\text { behavior determinants. }\end{array}$ & $\begin{array}{l}\text { There is a lack in the literature } \\
\text { of e-cycling regarding } \\
\text { behaviors and intention of } \\
\text { students in university campus. }\end{array}$ & $\begin{array}{l}\text { Results of this study indicated that there was a } \\
\text { positive relationship between moral norms and } \\
\text { attitudes and e-cycling behavior, also, perceived } \\
\text { convenience, the higher awareness of consequences } \\
\text { and more the e-cycling lead to more involvement in } \\
\text { e-cycling. }\end{array}$ \\
\hline Kura [229] & Public sector & 171 & Employees & $\begin{array}{l}\text { Transformational } \\
\text { leadership theory, } \\
\text { TPB }\end{array}$ & $\begin{array}{l}\text { Transformational leadership, } \\
\text { environmental concern and green } \\
\text { behaviour at work. }\end{array}$ & $\begin{array}{l}\text { The main objective of this } \\
\text { paper is to investigate the } \\
\text { mediating effect of } \\
\text { environmental concern } \\
\text { between green behaviour } \\
\text { and environmentally } \\
\text { specific transformational } \\
\text { leadership. }\end{array}$ & $\begin{array}{l}\text { Little attention has been paid } \\
\text { to the relationship between } \\
\text { environmental concern, green } \\
\text { behaviour and } \\
\text { environmentally specific } \\
\text { transformational leadership }\end{array}$ & $\begin{array}{l}\text { Results of this paper found that there was a } \\
\text { significant positive relationship between } \\
\text { transformational leadership and environmental } \\
\text { concern and positive direction with green } \\
\text { behaviour, and environmental concern is mediated } \\
\text { between green behaviour at work and } \\
\text { environmentally specific transformational } \\
\text { leadership. }\end{array}$ \\
\hline Ulubeyli [230] & $\begin{array}{c}\text { Cement } \\
\text { manufacturers }\end{array}$ & 267 & Managers & $\begin{array}{l}\text { Resource-based } \\
\text { theory }\end{array}$ & $\begin{array}{l}\text { Rivalry among existing } \\
\text { competitors, threat of new entrants, } \\
\text { bargaining power of buyers, } \\
\text { bargaining power of suppliers, } \\
\text { threat of substitutes, human } \\
\text { resource strategy, energy strategy, } \\
\text { raw material strategy } \\
\text { environmental performance. }\end{array}$ & $\begin{array}{l}\text { The main purpose of this } \\
\text { study is to examine the } \\
\text { influence of five industry } \\
\text { forces on implementation } \\
\text { input-based competitive } \\
\text { strategies and } \\
\text { environmental } \\
\text { performance. }\end{array}$ & $\begin{array}{l}\text { Lack of previous studies } \\
\text { regarding the integrating of } \\
\text { industry forces and } \\
\text { input-based techniques to } \\
\text { measuring environmental } \\
\text { performance. }\end{array}$ & $\begin{array}{l}\text { Findings of this study paper showed that there was } \\
\text { a positive relationship between plants and energy } \\
\text { strategy, also there was a positive relationship } \\
\text { between energy strategy and the lower threat of } \\
\text { new entrances. }\end{array}$ \\
\hline
\end{tabular}


Table A5. Breakdown of articles based on green and sustainable HRM.

\begin{tabular}{|c|c|c|c|c|c|c|c|c|}
\hline Author(s) Year & Scope and Sample & Sample Size & Respondents & Related Theory & Variables & Study Purpose & Gap and Research Problem & Results and Outcome \\
\hline Llach et al. [231] & Restaurants & 374 & $\begin{array}{l}\text { Firm's general } \\
\text { manager }\end{array}$ & $\begin{array}{l}\text { Institutional } \\
\text { theory }\end{array}$ & $\begin{array}{l}\text { Competitors, institutional support, } \\
\text { cleaner practices, cleaner } \\
\text { performance, markets success } \\
\text { factors and financial performance. }\end{array}$ & $\begin{array}{l}\text { The main goal of this } \\
\text { paper is to examine the } \\
\text { relationship among } \\
\text { competitors, institutional } \\
\text { support, cleaner practices, } \\
\text { cleaner performance, } \\
\text { market success factors and } \\
\text { financial performance. }\end{array}$ & $\begin{array}{l}\text { There is a lack in the literature } \\
\text { regarding adoption of cleaner } \\
\text { production and financial and } \\
\text { competitiveness. }\end{array}$ & $\begin{array}{l}\text { Findings of this paper showed that there was a } \\
\text { positive relationship between institutional support } \\
\text { and cleaner practices, and no relationship between } \\
\text { cleaner practices and competitors. }\end{array}$ \\
\hline Thieme et al. [232] & University & 467 & Students & TPB & $\begin{array}{l}\text { Environmental concern for wildlife, } \\
\text { environmental concern for waste, } \\
\text { environmental concern for energy, } \\
\text { environmental involvement, } \\
\text { willingness to pay more and } \\
\text { sustainable behaviors. }\end{array}$ & $\begin{array}{l}\text { The main objective of this } \\
\text { study is to examine the } \\
\text { relationship between } \\
\text { environmental concern, } \\
\text { sustainable behaviors, } \\
\text { environmental } \\
\text { involvement and } \\
\text { willingness to pay more. }\end{array}$ & $\begin{array}{l}\text { There was a gap in previous } \\
\text { studies regarding } \\
\text { environmental involvement } \\
\text { and willingness to pay more in } \\
\text { the relationship between } \\
\text { environmental concern and } \\
\text { sustainable behaviors. }\end{array}$ & $\begin{array}{l}\text { Results of this study indicated that there was the } \\
\text { mediating effect in the relationship between } \\
\text { willingness to pay more and environmental } \\
\text { involvement, environmental concern and } \\
\text { sustainable behaviors. }\end{array}$ \\
\hline $\begin{array}{l}\text { Iniesta-Bonill } \\
\text { et al. [233] }\end{array}$ & Tourism & 187 & Tourists & $\begin{array}{l}\text { Institutional } \\
\text { theory and } \\
\text { Stakeholder } \\
\text { theory }\end{array}$ & $\begin{array}{l}\text { Economic sustainability, cultural } \\
\text { sustainability, environmental } \\
\text { sustainability, satisfaction and } \\
\text { perceived value. }\end{array}$ & $\begin{array}{l}\text { The main purpose of this } \\
\text { study is to examine the } \\
\text { relationship between } \\
\text { perceived sustainability, } \\
\text { satisfaction and perceived } \\
\text { value of tourists. }\end{array}$ & $\begin{array}{l}\text { There is a lack in previous } \\
\text { studies regarding how } \\
\text { perceived sustainability } \\
\text { influence on tourist perception } \\
\text { based on market orientation } \\
\text { perspective. }\end{array}$ & $\begin{array}{l}\text { Results of this study found that there was a positive } \\
\text { relationship among all variable and all hypotheses } \\
\text { supported. }\end{array}$ \\
\hline $\begin{array}{l}\text { Castaneda } \\
\text { et al. [234] }\end{array}$ & Consumers & 1044 & Consumers & $\begin{array}{l}\text { Social capital } \\
\text { theory }\end{array}$ & $\begin{array}{l}\text { Social capital, knowledge of } \\
\text { environmental issues, } \\
\text { pro-environmental attitudes, } \\
\text { perceived eco-capability and } \\
\text { eco-behaviour. }\end{array}$ & $\begin{array}{l}\text { The purpose of this study } \\
\text { is to examine the effects of } \\
\text { social capital within a } \\
\text { community on the } \\
\text { adoption of consumer } \\
\text { eco-behaviour or } \\
\text { environmentally } \\
\text { sustainable behaviour of } \\
\text { consumers. }\end{array}$ & $\begin{array}{l}\text { The study extends the BPM by } \\
\text { offering a social capital view as } \\
\text { a more nuanced explanation of } \\
\text { consumer eco-behaviour. }\end{array}$ & $\begin{array}{l}\text { The results suggest the substantive influence of } \\
\text { social capital on environmental knowledge, } \\
\text { pro-environmental attitudes and eco-capability. } \\
\text { Both knowledge and attitudes have positive effects } \\
\text { on eco-capability, which in turn positively shapes } \\
\text { eco-behaviour. }\end{array}$ \\
\hline Guerci et al. [235] & $\begin{array}{l}\text { Manufacturing and } \\
\text { service companies }\end{array}$ & 74 & $\begin{array}{l}\text { HR Managers and } \\
\text { SC Managers } \\
\text { operating }\end{array}$ & $\begin{array}{l}\text { Stakeholder } \\
\text { theory }\end{array}$ & $\begin{array}{l}\text { Customer pressure, regulatory } \\
\text { stakeholder pressure, green hiring, } \\
\text { green training and involvement, } \\
\text { green performance management } \\
\text { and compensation and } \\
\text { environmental performance. }\end{array}$ & $\begin{array}{l}\text { The main purpose of this } \\
\text { article is to examine the } \\
\text { relationship between } \\
\text { green HRM practices, } \\
\text { customer pressure, } \\
\text { regulatory stakeholder } \\
\text { pressure, and } \\
\text { environmental } \\
\text { performance. }\end{array}$ & $\begin{array}{l}\text { There is a lack in previous } \\
\text { studies regarding customer } \\
\text { pressure and regulatory } \\
\text { stakeholder pressure in } \\
\text { relationship between green } \\
\text { HRM and environmental } \\
\text { performance. }\end{array}$ & $\begin{array}{l}\text { Findings of this paper showed that there was a } \\
\text { positive and significant relationship between } \\
\text { customer pressure and regulatory stakeholder } \\
\text { pressure and environmental performance, also there } \\
\text { was positive relationshiph between compensation, } \\
\text { involvement, green performance management } \\
\text { green training and environmental performance. }\end{array}$ \\
\hline
\end{tabular}


Table A6. Breakdown of articles based on environmental information technology and systems.

\begin{tabular}{|c|c|c|c|c|c|c|c|c|}
\hline Author(s) Year & Scope and Sample & Sample Size & Respondents & Related Theory & Variables & Study Purpose & Gap and Research Problem & Results and Outcome \\
\hline $\begin{array}{l}\text { Schniederjans and } \\
\text { Hales [245] }\end{array}$ & $\begin{array}{l}\text { Manufacturing and } \\
\text { service } \\
\text { organizations }\end{array}$ & 247 & $\begin{array}{c}\text { Top and middle } \\
\text { management }\end{array}$ & $\begin{array}{l}\text { Transaction cost } \\
\text { economics theory }\end{array}$ & $\begin{array}{l}\text { Computing, Collaboration, } \\
\text { Economic performance and } \\
\text { Environmental performance. }\end{array}$ & $\begin{array}{l}\text { The main goal of this } \\
\text { paper is to investigate the } \\
\text { influence of cloud } \\
\text { computing on } \\
\text { environmental and } \\
\text { economic performance by } \\
\text { mediation effect of } \\
\text { collaboration. }\end{array}$ & $\begin{array}{l}\text { There is a need to optimize } \\
\text { and balance environmental } \\
\text { and economic performance to } \\
\text { decrease the business impact } \\
\text { on natural environment. }\end{array}$ & $\begin{array}{l}\text { Outcomes of this paper found that collaboration did } \\
\text { not have an influence on environmental } \\
\text { performance, and partially mediates the } \\
\text { relationship between economic performance and } \\
\text { cloud computing. Moreover, there is a direct effect } \\
\text { between computing and economic and } \\
\text { environmental performance. }\end{array}$ \\
\hline Koo, Chung [246] & $\begin{array}{l}\text { Smart green } \\
\text { technology devices }\end{array}$ & 100 & Customers & $\begin{array}{l}\text { Motivation theory } \\
\text { and reference } \\
\text { group theory }\end{array}$ & $\begin{array}{l}\text { Social influence, Media influence, } \\
\text { Perceived enjoyment in a smart } \\
\text { green IT device, Perceived } \\
\text { environmental problem, Saving } \\
\text { money, Legislative pressure, } \\
\text { Perceived usefulness in a smart } \\
\text { green IT device and Continued use } \\
\text { of a smart green IT device. }\end{array}$ & $\begin{array}{l}\text { Examined the perceived } \\
\text { usefulness determinants of } \\
\text { smart green IT device for } \\
\text { decrease electricity } \\
\text { consumption. }\end{array}$ & $\begin{array}{l}\text { Very few previous studies } \\
\text { have been done about green IT } \\
\text { devices, social norms, } \\
\text { motivational values and usage } \\
\text { from the individual } \\
\text { consumer's perspective. }\end{array}$ & $\begin{array}{l}\text { Results of this paper found that intrinsic } \\
\text { motivations had a significant relationship with the } \\
\text { perceived usefulness and extrinsic motivations had } \\
\text { a strong relationship with the perceived usefulness } \\
\text { of this device. In addition, perceived usefulness had } \\
\text { strong relationship with the continued use of a } \\
\text { smart green IT device and reference group partially } \\
\text { can moderate this relationship. }\end{array}$ \\
\hline Wang et al. [247] & Manufacturing & $\begin{array}{l}151 \text { Chinese } \\
\text { firms }\end{array}$ & $\begin{array}{l}\text { Managers and } \\
\text { executive }\end{array}$ & $\begin{array}{l}\text { Natural } \\
\text { resource-based } \\
\text { theory }\end{array}$ & $\begin{array}{l}\text { IT technical infrastructure } \\
\text { flexibility, IT personnel skills IT- } \\
\text { business alignment, Environmental } \\
\text { orientation and Environmental } \\
\text { performance. }\end{array}$ & $\begin{array}{l}\text { The goal of this paper to } \\
\text { examine the relationship } \\
\text { between IT and } \\
\text { environmental } \\
\text { performance with } \\
\text { moderator role of } \\
\text { environmental orientation. }\end{array}$ & $\begin{array}{l}\text { There is a need in the literature } \\
\text { for a better understanding of } \\
\text { the role of IT as solution for } \\
\text { environmental sustainability. }\end{array}$ & $\begin{array}{l}\text { Findings of this paper showed IT-business } \\
\text { alignment and IT personnel skills can enable us to } \\
\text { combine IT in the environment and this can lead to } \\
\text { strong orientation to environmental sustainability. }\end{array}$ \\
\hline $\begin{array}{l}\text { Gholami } \\
\text { et al. [242] }\end{array}$ & $\begin{array}{l}\text { Service and } \\
\text { manufacturing } \\
\text { organizations }\end{array}$ & 405 & $\begin{array}{l}\text { Managerial } \\
\text { positions }\end{array}$ & $\begin{array}{l}\text { Institutional } \\
\text { theory }\end{array}$ & $\begin{array}{l}\text { Attitude, coercive pressure, } \\
\text { environmental performance, future } \\
\text { consequences, mimetic pressure, } \\
\text { pollution prevention, product } \\
\text { stewardship, sustainable } \\
\text { development }\end{array}$ & $\begin{array}{l}\text { Examined the perception } \\
\text { of senior managers in } \\
\text { relationship between } \\
\text { green IS and } \\
\text { environmental } \\
\text { performance. }\end{array}$ & $\begin{array}{l}\text { Few previous papers place an } \\
\text { emphasis on the adoption of } \\
\text { green IS in organization for } \\
\text { reduce the environmental } \\
\text { influence. }\end{array}$ & $\begin{array}{l}\text { Findings of this paper showed that the coercive } \\
\text { pressure impact of attitude toward green IS and } \\
\text { does not influence mimetic pressure. In addition, } \\
\text { there is a positive significant relationship between } \\
\text { attitude, green IS adoption and future consequences } \\
\text { consideration and green IS adoption had a } \\
\text { significant relationship with environmental } \\
\text { performance in the long term. }\end{array}$ \\
\hline $\begin{array}{l}\text { Akman and } \\
\text { Mishra [244] }\end{array}$ & $\begin{array}{l}\text { public- and } \\
\text { private-sector }\end{array}$ & 182 & Professional & $\begin{array}{c}\text { Technology } \\
\text { Acceptance Model }\end{array}$ & $\begin{array}{l}\text { Perceived ease-of-use, subjective } \\
\text { norms, level of awareness, } \\
\text { perceived usefulness, attitude } \\
\text { toward and actual system usage. }\end{array}$ & $\begin{array}{l}\text { The main goal of this } \\
\text { paper is to examine the } \\
\text { role of green information } \\
\text { technology in IT } \\
\text { professionalin private } \\
\text { and public sectors. }\end{array}$ & $\begin{array}{l}\text { There are few studies } \\
\text { regarding the green } \\
\text { information technology. }\end{array}$ & $\begin{array}{l}\text { Findings of this paper showed that there is diversity } \\
\text { among establishments from public- and } \\
\text { private-sectors in the impact of the PEU on PU and } \\
\text { on the ATU; TAM is important for private-sector } \\
\text { establishments excluding the relations between the } \\
\text { PEU and ATU and PEU and PU. }\end{array}$ \\
\hline $\begin{array}{l}\text { Meacham } \\
\text { et al. [248] }\end{array}$ & $\begin{array}{l}\text { US manufacturing } \\
\text { organizations }\end{array}$ & 159 & Managers & $\begin{array}{l}\text { Resource-based } \\
\text { theory }\end{array}$ & $\begin{array}{l}\text { Green information systems, } \\
\text { information sharing and } \\
\text { environmental performance. }\end{array}$ & $\begin{array}{l}\text { The main objective of this } \\
\text { article is to explore the } \\
\text { influence organization's } \\
\text { capability to share } \\
\text { information with focus on } \\
\text { green information system } \\
\text { for enhancing } \\
\text { environmental } \\
\text { performance. }\end{array}$ & $\begin{array}{l}\text { There is a need for } \\
\text { manufacturing companies to } \\
\text { improve their green } \\
\text { information systems capability } \\
\text { and information sharing to } \\
\text { improve environmental } \\
\text { performance in companies. }\end{array}$ & $\begin{array}{l}\text { Results of this study found that green information } \\
\text { systems had a partial mediator relationship } \\
\text { between environmental performance and supply } \\
\text { chain information sharing. }\end{array}$ \\
\hline
\end{tabular}


Table A6. Breakdown of articles based on environmental information technology and systems.

\begin{tabular}{|c|c|c|c|c|c|c|c|c|}
\hline Author(s) Year & Scope and Sample & Sample Size & Respondents & Related Theory & Variables & Study Purpose & Gap and Research Problem & Results and Outcome \\
\hline $\begin{array}{l}\text { Ryoo and } \\
\text { Koo [243] }\end{array}$ & $\begin{array}{c}\text { Manufacturing } \\
\text { firms }\end{array}$ & 77 & $\begin{array}{l}\text { Managerial } \\
\text { positions }\end{array}$ & RBV & $\begin{array}{l}\text { Green practices-IS alignment, } \\
\text { green practice-manufacturing } \\
\text { coordination, green } \\
\text { practices-marketing coordination, } \\
\text { environmental performance and } \\
\text { economic performance. }\end{array}$ & $\begin{array}{l}\text { The main purpose of this } \\
\text { paper is to develop a } \\
\text { model based on these } \\
\text { variables for green } \\
\text { practices-IS alignment, } \\
\text { green } \\
\text { practice-manufacturing } \\
\text { coordination, green } \\
\text { practices-marketing } \\
\text { coordination, } \\
\text { environmental } \\
\text { performance and } \\
\text { economic performance. }\end{array}$ & $\begin{array}{l}\text { There is a lack in the literature } \\
\text { regarding studies that } \\
\text { addressed business value of } \\
\text { green information systems. }\end{array}$ & $\begin{array}{l}\text { Findings of this paper showed that there was a } \\
\text { positive relationship between green practices-IS, } \\
\text { green practices-marketing coordination and } \\
\text { alignment green practices-manufacturing } \\
\text { coordination, and green practices-marketing } \\
\text { coordination and green practices-manufacturing } \\
\text { coordination were significiant predictors for } \\
\text { environmental performance, while green } \\
\text { practices--S alignment had an indirect relationship } \\
\text { with environmental performance by incorporating } \\
\text { green practices-marketing coordination and green } \\
\text { practices-manufacturing coordination. }\end{array}$ \\
\hline $\begin{array}{l}\text { Molla and } \\
\text { Abareshi [249] }\end{array}$ & Organizations & 176 & $\mathrm{CIOs} / \mathrm{IT}$ managers & $\begin{array}{l}\text { Motivational } \\
\text { theory }\end{array}$ & $\begin{array}{l}\text { Eco-efficiency, eco-responsiveness, } \\
\text { green IT and IT for green, } \\
\text { eco-effectiveness and } \\
\text { eco-legitimacy. }\end{array}$ & $\begin{array}{l}\text { The main purpose of this } \\
\text { article is to examine the } \\
\text { relationship between } \\
\text { motivation of } \\
\text { organizational } \\
\text { eco-sustainability and } \\
\text { green information } \\
\text { technology adoption and } \\
\text { information technology for } \\
\text { green IT. }\end{array}$ & $\begin{array}{l}\text { There is a lack in previous } \\
\text { studies regarding the } \\
\text { organizational } \\
\text { eco-sustainability motivation } \\
\text { and adoption of green } \\
\text { information technology and } \\
\text { information technology. }\end{array}$ & $\begin{array}{l}\text { Findings of this paper showed that } \\
\text { eco-effectiveness and eco-efficiency help } \\
\text { technologies to enhance the energy efficiency of } \\
\text { information technology infrastructure and decrease } \\
\text { information technology related to emissions. In } \\
\text { addition, information systems decreased travel. }\end{array}$ \\
\hline
\end{tabular}

Table A7. Breakdown of articles based on green and sustainable operation management.

\begin{tabular}{|c|c|c|c|c|c|c|c|c|}
\hline Author(s) Year & Scope and Sample & Sample Size & Respondents & Related Theory & Variables & Study Purpose & Gap and Research Problem & Results and Outcome \\
\hline $\begin{array}{l}\text { Campón-Cerro } \\
\text { et al. [261] }\end{array}$ & $\begin{array}{l}\text { rural tourism } \\
\text { destinations }\end{array}$ & $\begin{array}{l}464 \text { rural } \\
\text { tourists }\end{array}$ & Rural tourists & $\begin{array}{l}\text { Expectancy } \\
\text { disconfirmation } \\
\text { theory }\end{array}$ & $\begin{array}{l}\text { image, quality, value, attribute } \\
\text { satisfaction, overall satisfaction, } \\
\text { loyalty }\end{array}$ & $\begin{array}{l}\text { Investigated the role of } \\
\text { loyalty for sustainable } \\
\text { advantage and identify the } \\
\text { loyalty factors for } \\
\text { understanding of } \\
\text { destination loyalty. }\end{array}$ & $\begin{array}{l}\text { There is a need to examine } \\
\text { sustainable strategies such as } \\
\text { loyalty for rural tourism } \\
\text { destinations. }\end{array}$ & $\begin{array}{l}\text { Findings of this paper showed that quality, } \\
\text { destination attribute satisfaction and image were } \\
\text { the direct antecedents for loyalty in the rural } \\
\text { tourism destination. }\end{array}$ \\
\hline Sheu [265] & Electronic products & 237 consumer & Consumers & $\begin{array}{l}\text { Resource } \\
\text { dependence } \\
\text { theory }\end{array}$ & $\begin{array}{l}\text { Government intervention, power } \\
\text { shifts (countervailing power, } \\
\text { bargaining power), relationship } \\
\text { quality improvement (joint action, } \\
\text { relationship quality) and green } \\
\text { channel performance. }\end{array}$ & $\begin{array}{l}\text { Examined the influence of } \\
\text { government intervention } \\
\text { on green channel } \\
\text { performance with } \\
\text { mediating effects of } \\
\text { relationship quality } \\
\text { improvement and channel } \\
\text { power shifts. }\end{array}$ & $\begin{array}{l}\text { There is a need for anew } \\
\text { conceptual model regarding } \\
\text { government intervention, } \\
\text { relationship quality } \\
\text { improvement in in } \\
\text { producer-retailer green } \\
\text { channel dyads. }\end{array}$ & $\begin{array}{l}\text { Findings of this paper showed that there is a } \\
\text { positive relationship between government } \\
\text { intervention and green channel performance. }\end{array}$ \\
\hline Blohmke et al. [262] & Private sector & $\begin{array}{l}\text { data set of } 47 \\
\text { countries }\end{array}$ & $\begin{array}{l}\text { Senior-and middle } \\
\text { level managers }\end{array}$ & $\begin{array}{l}\text { Environmental } \\
\text { policy theory }\end{array}$ & $\begin{array}{l}\text { Green Advocacy, Awareness, } \\
\text { Governance Capacity, international } \\
\text { environmental governance and } \\
\text { national environmental policy. }\end{array}$ & $\begin{array}{l}\text { Evaluated the } \\
\text { determinants of } \\
\text { environmental policy on } \\
\text { international } \\
\text { environmental governance } \\
\text { and national } \\
\text { environmental policy. }\end{array}$ & $\begin{array}{l}\text { Need for analysis of } \\
\text { interaction among } \\
\text { environmental policy } \\
\text { determinants. }\end{array}$ & $\begin{array}{l}\text { Finding of this study demonstrated that } \\
\text { government capacity and green industry advocacy } \\
\text { have positive impact on environmental policy. }\end{array}$ \\
\hline
\end{tabular}


Table A7. Breakdown of articles based on green and sustainable operation management.

\begin{tabular}{|c|c|c|c|c|c|c|c|c|}
\hline Author(s) Year & Scope and Sample & Sample Size & Respondents & Related Theory & Variables & Study Purpose & Gap and Research Problem & Results and Outcome \\
\hline $\begin{array}{l}\text { Gelhard and von } \\
\text { Delft [266] }\end{array}$ & Chemical firms & 99 & Top-level managers & $\begin{array}{l}\text { Dynamic } \\
\text { resource-based } \\
\text { theory (DRBT) }\end{array}$ & $\begin{array}{l}\text { Strategic flexibility, Value chain } \\
\text { flexibility, Customer integration } \\
\text { and Sustainability performance. }\end{array}$ & $\begin{array}{l}\text { Investigated the } \\
\text { relationshipamong } \\
\text { strategic flexibility and } \\
\text { sustainability performance } \\
\text { with mediating effect of } \\
\text { customer integration and } \\
\text { value chain flexibility. }\end{array}$ & $\begin{array}{l}\text { Previous studies did not } \\
\text { consider the important role of } \\
\text { organizational capabilities for } \\
\text { attain superior sustainability } \\
\text { performance. }\end{array}$ & $\begin{array}{l}\text { Results of this paper showed that customer } \\
\text { integration and value chain flexibility can be a } \\
\text { mediation between strategic flexibility and } \\
\text { sustainability performance. }\end{array}$ \\
\hline Fraj et al. [267] & Spanish hotels & 232 & $\begin{array}{l}\text { hotels' }^{\prime} \\
\text { environmental } \\
\text { manager or hotel } \\
\text { director }\end{array}$ & $\begin{array}{l}\text { Theory of } \\
\text { Dynamic } \\
\text { Capabilities }\end{array}$ & $\begin{array}{l}\text { Learning orientation, Proactive } \\
\text { environmental strategy and } \\
\text { Organizational competitiveness. }\end{array}$ & $\begin{array}{l}\text { The main aim of this } \\
\text { article is to examine the } \\
\text { relationship among } \\
\text { organizational capabilities, } \\
\text { competitive and proactive } \\
\text { environmental strategies. }\end{array}$ & $\begin{array}{l}\text { There are few previous papers } \\
\text { that explore the relationship } \\
\text { between environmental and } \\
\text { organizational capabilities } \\
\text { with competitive performance. }\end{array}$ & $\begin{array}{l}\text { Results of this paper found that there is a } \\
\text { relationship betteeen innovition and proactive } \\
\text { environmental strategy organizational } \\
\text { competitiveness. In addition, learning orientation } \\
\text { deos directly predict organizational } \\
\text { competitiveness }\end{array}$ \\
\hline $\begin{array}{l}\text { Prud'homme and } \\
\text { Raymond [268] }\end{array}$ & Hotel industry & 473 & Customers & - & $\begin{array}{l}\text { Customer intentions, Customer } \\
\text { satisfaction, Hotel selection criteria, } \\
\text { Responsible behaviors, Age, } \\
\text { Gender, Education, Purpose, } \\
\text { Length }\end{array}$ & $\begin{array}{l}\text { The main objective of this } \\
\text { paper is to examine the } \\
\text { relationship between } \\
\text { sustainable development, } \\
\text { customer satisfaction and } \\
\text { customer intention in the } \\
\text { hotel industry. }\end{array}$ & $\begin{array}{l}\text { There is a lack of previous } \\
\text { studies focusing on customer } \\
\text { satisfaction in sustainable } \\
\text { development. }\end{array}$ & $\begin{array}{l}\text { Results of this paper found that there is a positive } \\
\text { relationship between customer satisfaction and } \\
\text { sustainable development practices with different } \\
\text { levels of satisfaction in hotels' ownership and size. }\end{array}$ \\
\hline Lai and Cheng [263] & University & 266 & Students & $\begin{array}{c}\text { Theory of planned } \\
\text { behavior }\end{array}$ & $\begin{array}{l}\text { Perceptions, attitudes, problems, } \\
\text { responsibility, willingness and } \\
\text { behavior. }\end{array}$ & $\begin{array}{l}\text { The main aim of this study } \\
\text { is to investigate the } \\
\text { influence of } \\
\text { undergraduate students } \\
\text { regarding green marketing } \\
\text { practices and their attitude } \\
\text { toward the environment, } \\
\text { their environmental } \\
\text { responsibility and their } \\
\text { perceived environmental } \\
\text { problem seriousness. }\end{array}$ & $\begin{array}{l}\text { Few previous studies have } \\
\text { focused on perceptions of } \\
\text { students in green marketing } \\
\text { practices. }\end{array}$ & $\begin{array}{l}\text { Results of this paper found that there is a strong } \\
\text { relationship between perceived environmental } \\
\text { responsibility and green products purchase } \\
\text { willingness, also there is no relationship between } \\
\text { perceived seriousness of environmental problems } \\
\text { and undergraduate students' green product } \\
\text { purchase willingness and there are significant } \\
\text { relationships between students' willingness to } \\
\text { purchase green products and their green purchase } \\
\text { behavior. }\end{array}$ \\
\hline Jabbour et al. [269] & $\begin{array}{l}\text { Brazilian electronic } \\
\text { sector }\end{array}$ & 100 & Managers & None & $\begin{array}{l}\text { Internal environmental } \\
\text { management, Green purchasing, } \\
\text { Cooperation with customers, } \\
\text { Eco-design, Investment recover } \\
\text { and Maturity of environmental } \\
\text { management }\end{array}$ & $\begin{array}{l}\text { The main objective of this } \\
\text { study is to examine the } \\
\text { relationship between } \\
\text { GSCM and the maturity } \\
\text { levels of environmental } \\
\text { management. }\end{array}$ & $\begin{array}{l}\text { There is a lack in the literature } \\
\text { regarding the relationship } \\
\text { between GSCM and the } \\
\text { maturity levels of } \\
\text { environmental management. }\end{array}$ & $\begin{array}{l}\text { Findings of this paper showed that the maturity } \\
\text { level of environmental management impacted on } \\
\text { the adoption of GSCM. }\end{array}$ \\
\hline Luzzini et al. [264] & $\begin{array}{l}\text { Ten European and } \\
\text { North American } \\
\text { countries }\end{array}$ & 383 & $\begin{array}{l}\text { Procurement } \\
\text { executives }\end{array}$ & $\begin{array}{l}\text { Resource-Based } \\
\text { Theory (RBT) }\end{array}$ & $\begin{array}{l}\text { collaborative capabilities, } \\
\text { sustainability commitment, and } \\
\text { performance }\end{array}$ & $\begin{array}{l}\text { The purpose of this paper } \\
\text { is to examine the } \\
\text { relationship between } \\
\text { sustainability } \\
\text { commitment, collaborative } \\
\text { capabilities and } \\
\text { performance. }\end{array}$ & $\begin{array}{l}\text { There is a lack in previous } \\
\text { studies in relation to } \\
\text { sustainability commitments on } \\
\text { the development of } \\
\text { collaborative capabilities for } \\
\text { supply functions and } \\
\text { purchasing on sustainability } \\
\text { performance. }\end{array}$ & $\begin{array}{l}\text { Findings of this paper showed that there is a link } \\
\text { between sustainability commitment and } \\
\text { collaborative capabilities, cost performance and } \\
\text { social and environmental performance. }\end{array}$ \\
\hline Murovec et al. [270] & $\begin{array}{l}\text { Companies in } \\
\text { Slovenia }\end{array}$ & 269 & $\begin{array}{l}\text { Chief executive } \\
\text { office }\end{array}$ & $\begin{array}{l}\text { Conventional } \\
\text { economic theory }\end{array}$ & $\begin{array}{l}\text { Financial incentives, Tax measures, } \\
\text { Regulation and non-market } \\
\text { instruments, Past environmental } \\
\text { investments, Perception of costs, } \\
\text { Importance for customers and firm } \\
\text { performance. }\end{array}$ & $\begin{array}{l}\text { The main goal of this } \\
\text { paper is to examine the } \\
\text { environmental } \\
\text { technologies for increasing } \\
\text { policy application. }\end{array}$ & $\begin{array}{l}\text { Need for more quantitative } \\
\text { evidence regarding the } \\
\text { environmental technologies. }\end{array}$ & $\begin{array}{l}\text { Findings of this study indicated that past } \\
\text { environmental investments and policy measures } \\
\text { were important to firm performance and customers } \\
\text { and had a positive impact on environmental } \\
\text { investments. }\end{array}$ \\
\hline
\end{tabular}


Table A7. Breakdown of articles based on green and sustainable operation management.

\begin{tabular}{|c|c|c|c|c|c|c|c|c|}
\hline Author(s) Year & Scope and Sample & Sample Size & Respondents & Related Theory & Variables & Study Purpose & Gap and Research Problem & Results and Outcome \\
\hline Jabbour et al. [256] & $\begin{array}{l}\text { ISO 9001-certified } \\
\text { companies }\end{array}$ & 62 & $\begin{array}{l}\text { Owners/top } \\
\text { managers }\end{array}$ & $\begin{array}{l}\text { Ecological } \\
\text { modernization }\end{array}$ & $\begin{array}{l}\text { Environmental practices, } \\
\text { operational performance, } \\
\text { human/organizational aspects, } \\
\text { green performance, Technological } \\
\text { aspects and market performance. }\end{array}$ & $\begin{array}{l}\text { The main objective of this } \\
\text { paper is to investigate the } \\
\text { relationship between GPD } \\
\text { practices on firm } \\
\text { performance such as } \\
\text { market, environmental } \\
\text { and operational aspects. }\end{array}$ & $\begin{array}{l}\text { There is a lack in the literature } \\
\text { regarding the GPD in Brazil. }\end{array}$ & $\begin{array}{l}\text { Results of this paper found that GP practices } \\
\text { affected firm performance and technical aspects. }\end{array}$ \\
\hline Maniatis [271] & Shoppers & 253 & Green shoppers & Schwartz's theory & $\begin{array}{l}\text { Knowledge of environmental } \\
\text { issues, knowledge of } \\
\text { environmental solutions, } \\
\text { knowledge of ecological, labeling, } \\
\text { knowledge of environmental } \\
\text { benefits, knowledge of economic } \\
\text { benefits, commitment to } \\
\text { environmental protection, } \\
\text { commitment to wastage reduction, } \\
\text { commitment to cost reduction, } \\
\text { commitment to health benefits, } \\
\text { presence of ecological labels, } \\
\text { presence of environmental } \\
\text { certification, presence of } \\
\text { non-polluting ingredients, } \\
\text { presence of recyclable packaging, } \\
\text { opportunity for cost reduction, } \\
\text { nice and clean appearance. }\end{array}$ & $\begin{array}{l}\text { The main objective of this } \\
\text { paper is to examine the } \\
\text { impact of general } \\
\text { awareness, commitment to } \\
\text { green products. }\end{array}$ & $\begin{array}{l}\text { There is a lack regarding } \\
\text { structural constructs and study } \\
\text { of how they interact with } \\
\text { consumers' green dimensions. }\end{array}$ & $\begin{array}{l}\text { Results of this study indicated that the selected } \\
\text { indicators reflected the impact of general awareness } \\
\text { and commitment to green products. }\end{array}$ \\
\hline Reuter et al. [272] & $\begin{array}{l}\text { Multinational } \\
\text { industrial } \\
\text { companies }\end{array}$ & 71 & $\begin{array}{c}\text { Purchasing } \\
\text { managers }\end{array}$ & $\begin{array}{l}\text { Stakeholder } \\
\text { theory }\end{array}$ & $\begin{array}{l}\text { Sustainability prevalence in } \\
\text { supplier selection, cost prevalence } \\
\text { in supplier selection, shareholder } \\
\text { orientation, public orientation, } \\
\text { customer orientation and } \\
\text { formalization of ethical culture. }\end{array}$ & $\begin{array}{l}\text { The main objective of this } \\
\text { paper is to examine the } \\
\text { relationship between } \\
\text { stakeholder orientation, } \\
\text { sustainability and cost } \\
\text { prevalence in process of } \\
\text { supplier selection. }\end{array}$ & $\begin{array}{l}\text { There is concern about } \\
\text { companies regarding } \\
\text { understanding how } \\
\text { purchasing managers impact } \\
\text { on stakeholder in process of } \\
\text { supplier selection. }\end{array}$ & $\begin{array}{l}\text { Results of this paper found that shareholder } \\
\text { orientation had a negative impact on sustainability } \\
\text { prevalence in the process of supplier selection, and } \\
\text { also public orientation had a positive relationship } \\
\text { with sustainability prevalence. }\end{array}$ \\
\hline Chekima et al. [273] & Customers & 405 & $\begin{array}{l}\text { Male and female } \\
\text { customers }\end{array}$ & $\begin{array}{l}\text { Theory of planned } \\
\text { behavior (TPB) } \\
\text { and Value } \\
\text { Orientation } \\
\text { Theory }\end{array}$ & $\begin{array}{l}\text { Environmental knowledge, } \\
\text { Environmental advertising, Green } \\
\text { purchase intentions, Man-nature } \\
\text { orientation and Long-term } \\
\text { orientation. }\end{array}$ & $\begin{array}{l}\text { The main goal of this } \\
\text { paper is to investigate the } \\
\text { relationship between } \\
\text { cultural values, } \\
\text { environmental advertising } \\
\text { environmental knowledge } \\
\text { and determine the } \\
\text { moderating effect of } \\
\text { education level, income } \\
\text { level and gender on } \\
\text { consumers' green } \\
\text { purchase intentions. }\end{array}$ & $\begin{array}{l}\text { There is a lack in previous } \\
\text { studies regarding examining } \\
\text { the effectiveness of forming a } \\
\text { positive attitude and } \\
\text { encouraging consumers' } \\
\text { intentions to buy green } \\
\text { products. }\end{array}$ & $\begin{array}{l}\text { Results of this article found that environmental } \\
\text { advertising and cultural values were the main } \\
\text { influences in building green purchase intentions, } \\
\text { although environmental knowledge is not } \\
\text { significantly related to green purchase intentions. } \\
\text { Also, the results show that gender and education } \\
\text { level had a significant positive moderation effect } \\
\text { while income did not. }\end{array}$ \\
\hline $\begin{array}{l}\text { Hanim Mohamad } \\
\text { Zailani et al. [274] }\end{array}$ & $\begin{array}{c}\text { EMS ISO } \\
14001-\text { certified } \\
\text { manufacturing firms }\end{array}$ & 132 & Firms & $\begin{array}{l}\text { Institutional } \\
\text { theory }\end{array}$ & $\begin{array}{l}\text { Regulation and incentive, } \\
\text { eco-design, customer pressure and } \\
\text { environmental performance } \\
\text { outcome. }\end{array}$ & $\begin{array}{l}\text { The main aim of this paper } \\
\text { is to examine the } \\
\text { relationship among } \\
\text { eco-design, government } \\
\text { regulations and incentives, } \\
\text { customer pressures and } \\
\text { environmental } \\
\text { performance. }\end{array}$ & $\begin{array}{l}\text { Little attention has been paid } \\
\text { regarding external institutional } \\
\text { drivers which help firma to } \\
\text { adopt internal proactive } \\
\text { environmental strategies. }\end{array}$ & $\begin{array}{l}\text { Results of this paper found that external } \\
\text { institutional drivers directly and indirectly impact } \\
\text { of firm's environmental performance through its } \\
\text { internal proactive environmental strategy. }\end{array}$ \\
\hline
\end{tabular}


Table A7. Breakdown of articles based on green and sustainable operation management.

\begin{tabular}{|c|c|c|c|c|c|c|c|c|}
\hline Author(s) Year & Scope and Sample & Sample Size & Respondents & Related Theory & Variables & Study Purpose & Gap and Research Problem & Results and Outcome \\
\hline Hong et al. [275] & Manufacturing units & 711 & Managers & None & $\begin{array}{l}\text { Competitive market environment, } \\
\text { strategic green orientation, } \\
\text { integrated product development, } \\
\text { supply chain coordination, green } \\
\text { performance outcomes and } \\
\text { business unit performance. }\end{array}$ & $\begin{array}{l}\text { The main purpose of this } \\
\text { paper is to examine the } \\
\text { relationship between } \\
\text { strategic green } \\
\text { orientations, supply chain } \\
\text { coordination integrated } \\
\text { product development and } \\
\text { green performance } \\
\text { outcomes and business } \\
\text { unit performance. }\end{array}$ & $\begin{array}{l}\text { Need to understand strategic } \\
\text { green orientation, products } \\
\text { development practices and } \\
\text { supply chain coordination. }\end{array}$ & $\begin{array}{l}\text { Results of this paper found that commitment on } \\
\text { strategic green orientation is very important for } \\
\text { manufacturing firms and there was a positive } \\
\text { relationship between integrated product } \\
\text { development and supply chain coordination, and } \\
\text { there was a direct relationship between strategic } \\
\text { green orientations. The second hypothesis predicts } \\
\text { a positive relationship between strategic green } \\
\text { orientations and green performance outcomes. }\end{array}$ \\
\hline $\begin{array}{l}\text { Chen and } \\
\text { Chang [276] }\end{array}$ & $\begin{array}{l}\text { Manufacturing } \\
\text { industry }\end{array}$ & 152 & $\begin{array}{l}\text { CEOs or the } \\
\text { managers }\end{array}$ & None & $\begin{array}{l}\text { Environmental commitments, } \\
\text { green intangible assets and green } \\
\text { competitive advantages. }\end{array}$ & $\begin{array}{l}\text { The main purpose of this } \\
\text { paper is to investigate the } \\
\text { relationship between } \\
\text { environmental } \\
\text { commitment, green } \\
\text { competitive advantage } \\
\text { and green intangible } \\
\text { assets. }\end{array}$ & $\begin{array}{l}\text { Few previous studies have } \\
\text { focused on the impact of } \\
\text { international environmental } \\
\text { regulations and } \\
\text { environmentalism of } \\
\text { consumers on corporate } \\
\text { competitive advantages. }\end{array}$ & $\begin{array}{l}\text { Results of this study indicated that environmental } \\
\text { commitments and green intangible assets had a } \\
\text { positive relationship with green competitive } \\
\text { advantages. }\end{array}$ \\
\hline Blome et al. [257] & $\begin{array}{l}\text { Services and } \\
\text { manufacturing firms }\end{array}$ & 114 & $\begin{array}{l}\text { Senior procurement } \\
\text { professionals }\end{array}$ & $\begin{array}{l}\text { Resource-based } \\
\text { view, legitimacy } \\
\text { theory and } \\
\text { institutional } \\
\text { theory }\end{array}$ & $\begin{array}{l}\text { Market performance, financial } \\
\text { performance, top management } \\
\text { commitment, green procurement, } \\
\text { green supplier development and } \\
\text { supplier performance. }\end{array}$ & $\begin{array}{l}\text { The main objective of this } \\
\text { paper is to explore the } \\
\text { relationship between } \\
\text { market performance, } \\
\text { financial performance, top } \\
\text { management commitment, } \\
\text { green procurement, green } \\
\text { supplier development and } \\
\text { supplier performance. }\end{array}$ & $\begin{array}{l}\text { There is a lack in the literature } \\
\text { regarding firm-level } \\
\text { antecedents for green supplier } \\
\text { development and green } \\
\text { procurement which influence } \\
\text { supplier performance. }\end{array}$ & $\begin{array}{l}\text { Findings of this paper indicated that there was a } \\
\text { positive relationship between buying firms's market } \\
\text { performance and adoption of green procurement, } \\
\text { also, there was no relationship between financial } \\
\text { performance and green procurement, and top } \\
\text { management commitment was the important factor } \\
\text { regarding the green supplier development and } \\
\text { green procurement. There was a mediation } \\
\text { relationship between green procurement, supplier } \\
\text { performance and green supplier development. }\end{array}$ \\
\hline Lirn et al. [258] & $\begin{array}{l}\text { Shipping companies } \\
\text { and agencies }\end{array}$ & 80 & Managers & RBV & $\begin{array}{l}\text { Green shipping management } \\
\text { capability dimensions, namely, } \\
\text { greener policy, greener ships, and } \\
\text { greener suppliers, environmental } \\
\text { performance and financial } \\
\text { performance }\end{array}$ & $\begin{array}{l}\text { The main objective of this } \\
\text { paper is to identify the } \\
\text { green shipping } \\
\text { management capability } \\
\text { and its impact on firm } \\
\text { performance. }\end{array}$ & $\begin{array}{l}\text { There is a gap in the literature } \\
\text { regarding the relationship } \\
\text { between firm performance and } \\
\text { green shipping management }\end{array}$ & $\begin{array}{l}\text { Results of this paper found that there was a positive } \\
\text { and direct relationship between greener policy and } \\
\text { greener suppliers and greener ships, also there was } \\
\text { positive and indirect relationship between greener } \\
\text { policy, greener suppliers, environmental } \\
\text { performance and financial performance. }\end{array}$ \\
\hline W. Clark et al. [277] & $\begin{array}{l}\text { Manufacturing } \\
\text { plants }\end{array}$ & 257 & $\begin{array}{l}\text { Manufacturing } \\
\text { managers }\end{array}$ & $\begin{array}{c}\text { Market } \\
\text { orientation theory }\end{array}$ & $\begin{array}{l}\text { Market orientation, green } \\
\text { purchasing, logistics performance. }\end{array}$ & $\begin{array}{l}\text { The main objective of this } \\
\text { paper is to developed the } \\
\text { framework for } \\
\text { market-oriented } \\
\text { sustainability, green } \\
\text { purchasing and logistics } \\
\text { performance. }\end{array}$ & $\begin{array}{l}\text { There is a lack of previous } \\
\text { studies to develop and assess } \\
\text { the mark-oriented } \\
\text { sustainability framework. }\end{array}$ & $\begin{array}{l}\text { Results of this paper found that there was a positive } \\
\text { relationship green purchasing, market orientation } \\
\text { and logistics performance. }\end{array}$ \\
\hline $\begin{array}{l}\text { Felix and } \\
\text { Braunsberger [259] }\end{array}$ & Mexican population & 242 & Consumers & $\begin{array}{l}\text { Marketing and } \\
\text { consistency } \\
\text { theories }\end{array}$ & $\begin{array}{l}\text { Intrinsic religious orientation, } \\
\text { environmental attitudes and green } \\
\text { product purchases. }\end{array}$ & $\begin{array}{l}\text { The objective of this paper } \\
\text { is to examine the influence } \\
\text { of intrinsic religious } \\
\text { orientation on green } \\
\text { product purchases and } \\
\text { environmental attitudes. }\end{array}$ & $\begin{array}{l}\text { Need to focus on consumers' } \\
\text { environmentally-friendly } \\
\text { attitudes and behaviors in } \\
\text { developing countries. }\end{array}$ & $\begin{array}{l}\text { Findings of this paper showed that there was a } \\
\text { significant relationship between green product } \\
\text { purchases and environmental attitudes. }\end{array}$ \\
\hline Green et al. [278] & $\begin{array}{l}\text { Manufacturing } \\
\text { plants }\end{array}$ & 225 & $\begin{array}{c}\text { Plant-level } \\
\text { managers }\end{array}$ & $\begin{array}{l}\text { Resource-advantage } \\
\text { theory }\end{array}$ & $\begin{array}{l}\text { Internal environmental } \\
\text { management, investment recovery, } \\
\text { green purchasing, market } \\
\text { orientation, cooperation with } \\
\text { customers, environmental } \\
\text { performance and eco-design. }\end{array}$ & $\begin{array}{l}\text { The main purpose of this } \\
\text { paper is to examine the } \\
\text { relationship between } \\
\text { market orientation and } \\
\text { green SCM practices and } \\
\text { environmental } \\
\text { performance. }\end{array}$ & $\begin{array}{l}\text { There is a lack of previous } \\
\text { study regarding } \\
\text { environmental sustainability } \\
\text { and market orientation. }\end{array}$ & $\begin{array}{l}\text { Results of this paper showed that the market } \\
\text { indicated a direct and indirect relationship between } \\
\text { green SCM and environmental performance. }\end{array}$ \\
\hline
\end{tabular}


Table A7. Breakdown of articles based on green and sustainable operation management.

\begin{tabular}{|c|c|c|c|c|c|c|c|c|}
\hline Author(s) Year & Scope and Sample & Sample Size & Respondents & Related Theory & Variables & Study Purpose & Gap and Research Problem & Results and Outcome \\
\hline $\begin{array}{l}\text { Tirado-Valencia } \\
\text { et al. [279] }\end{array}$ & Local governments & 142 & Employee & $\begin{array}{l}\text { Stakeholder and } \\
\text { Legitimacy } \\
\text { theories }\end{array}$ & $\begin{array}{l}\text { Strategy and analysis, organisation } \\
\text { profile, information parameters, } \\
\text { governance, commitments and } \\
\text { stakeholders' participation, } \\
\text { economic-financial performance, } \\
\text { budgetary information, economic } \\
\text { information disclosed, social } \\
\text { indicators, environmental } \\
\text { initiatives and environmental } \\
\text { resources consumption. }\end{array}$ & $\begin{array}{l}\text { The main objective of this } \\
\text { study is to examine the } \\
\text { relationships between } \\
\text { nature and amount of } \\
\text { information and strategies } \\
\text { and the government of city } \\
\text { councils, and } \\
\text { sustainability performance } \\
\text { dimensions. }\end{array}$ & $\begin{array}{l}\text { There is a lack in the literature } \\
\text { regarding sustainability } \\
\text { information in local } \\
\text { government. }\end{array}$ & $\begin{array}{l}\text { Results of this paper show that there was a positive } \\
\text { relationship strategy. Moreover, the parameters of } \\
\text { information and economic block, ceonomic } \\
\text { performance, and the strategy and dissemination of } \\
\text { the parameters of the information were the } \\
\text { important factors in social indicators. The strategy } \\
\text { and the parameters of the information were } \\
\text { determinant in environmental initiatives and } \\
\text { investments. }\end{array}$ \\
\hline Li et al. [280] & High-tech firms & 256 & Senior managers & $\begin{array}{l}\text { Stakeholder } \\
\text { theory and natural } \\
\text { resource-based } \\
\text { view }\end{array}$ & $\begin{array}{l}\text { Environmental orientation, green } \\
\text { product design, green purchasing, } \\
\text { green manufacturing, green is, } \\
\text { environmental performance and } \\
\text { financial performance. }\end{array}$ & $\begin{array}{l}\text { The main objective of this } \\
\text { paper is to explore the } \\
\text { relationship between } \\
\text { green SCM capabilities } \\
\text { and environmental and } \\
\text { financial performance. }\end{array}$ & $\begin{array}{l}\text { There is a need to devote } \\
\text { attention to the environmental } \\
\text { capabilities such as green SCM } \\
\text { and environmental and } \\
\text { financial performance } \\
\text { measures. }\end{array}$ & $\begin{array}{l}\text { Findings of this paper showed that there was a } \\
\text { significant relationship between green SC processes, } \\
\text { green product design, firms' financial and } \\
\text { environmental performance, although, there was no } \\
\text { direct relationship between green product design } \\
\text { and financial performance. }\end{array}$ \\
\hline Li et al. [281] & Export SMEs & 305 & $\begin{array}{l}\text { Senior managers or } \\
\text { middle managers }\end{array}$ & $\begin{array}{l}\text { Stakeholder } \\
\text { theory }\end{array}$ & $\begin{array}{l}\text { Market-oriented environmental } \\
\text { sustainability, knowledge } \\
\text { integration, international buyer } \\
\text { involvement and export market } \\
\text { performance. }\end{array}$ & $\begin{array}{l}\text { The main objective of this } \\
\text { article is to investigate } \\
\text { how export supplier's } \\
\text { market-oriented } \\
\text { environmental } \\
\text { sustainability improves } \\
\text { the business performance } \\
\text { in organizations. }\end{array}$ & $\begin{array}{l}\text { Few previous studies have } \\
\text { devoted their attention to the } \\
\text { strategic role of upstream } \\
\text { suppliers. }\end{array}$ & $\begin{array}{l}\text { Results of this study found that relational capacity } \\
\text { of knowledge integration mediated the relationship } \\
\text { between market-oriented environmental } \\
\text { sustainability and business performance. }\end{array}$ \\
\hline $\begin{array}{l}\text { Stolz and } \\
\text { Bautista [260] }\end{array}$ & Consumers & 989 & Consumers & $\begin{array}{l}\text { Sustainability } \\
\text { theory }\end{array}$ & $\begin{array}{l}\text { Communication, placement, } \\
\text { price-quality and consumer effort. }\end{array}$ & $\begin{array}{l}\text { The main objective of this } \\
\text { paper is to examine the } \\
\text { relationship between } \\
\text { environmental } \\
\text { sustainability and } \\
\text { purchasing consumer } \\
\text { goods. }\end{array}$ & $\begin{array}{l}\text { There is a lack in previous } \\
\text { studies regarding the } \\
\text { importance that older } \\
\text { consumers attach to } \\
\text { environmental image and } \\
\text { buying consumer goods. }\end{array}$ & $\begin{array}{l}\text { Findings of this study showed that there was } \\
\text { significant relationship between price--uality and } \\
\text { consumer effort, and no-significiant relationship } \\
\text { between communication, consumer effort } \\
\text { placement and consumer effort. There was a partial } \\
\text { relationship between the perception of } \\
\text { price/quality significantly and consumer effort. }\end{array}$ \\
\hline $\begin{array}{l}\text { Chen and } \\
\text { Hung [282] }\end{array}$ & Green consumers & 406 & Consumers & TPB & $\begin{array}{l}\text { Attitude, subjective norm, } \\
\text { perceived behavioral control, social } \\
\text { impression, environmental ethics } \\
\text { and beliefs, environmental } \\
\text { consciousness and behavioral } \\
\text { intention. }\end{array}$ & $\begin{array}{l}\text { The main objective of this } \\
\text { paper is to determine } \\
\text { green product acceptance } \\
\text { based on the theory of } \\
\text { planned behavior and } \\
\text { social impression, } \\
\text { environmental ethics and } \\
\text { beliefs, environmental } \\
\text { consciousness and } \\
\text { behavioral intention. }\end{array}$ & $\begin{array}{l}\text { Few previous studies have } \\
\text { used the theory of planned } \\
\text { behavior for investigating } \\
\text { environmental cognitions of } \\
\text { individuals. }\end{array}$ & $\begin{array}{l}\text { Results of this paper found there was a positive } \\
\text { relationship between perceived behavioral control, } \\
\text { the environmental ethics attitude, environmental } \\
\text { consciousness of consumers and beliefs of } \\
\text { consumers, but social impression consumers and } \\
\text { subjective norms consumers had a positive and } \\
\text { non-significant relationship to intentions towards } \\
\text { using green products. }\end{array}$ \\
\hline Yusof et al. [283] & $\begin{array}{l}\text { Lake and river } \\
\text { resorts }\end{array}$ & 529 & Guests & None & $\begin{array}{l}\text { Resorts' environmental practices, } \\
\text { Environmental knowledge, } \\
\text { Environmental concern, Direct } \\
\text { environmental behaviours, Indirect } \\
\text { environmental behaviours and } \\
\text { Tourists' loyalty. }\end{array}$ & $\begin{array}{l}\text { The main purpose of this } \\
\text { article is to examine the } \\
\text { relationship between } \\
\text { environmental knowledge, } \\
\text { environmental concern, } \\
\text { environmental behaviours } \\
\text { of tourists, the } \\
\text { environmental practices of } \\
\text { resorts and tourists' } \\
\text { loyalty. }\end{array}$ & $\begin{array}{l}\text { Need to place more emphasis } \\
\text { on environmental awareness, } \\
\text { environmental knowledge and } \\
\text { environmental behaviour. }\end{array}$ & $\begin{array}{l}\text { Results of this paper demonstrated that there was a } \\
\text { significant relationship between the resorts' } \\
\text { environmental practices and tourists' loyalty, also } \\
\text { environmental concern regarding direct } \\
\text { environmental behaviours, and indirect } \\
\text { environmental behaviours showed a positive } \\
\text { relationship between the resorts' environmental } \\
\text { practices and tourists' loyalty. }\end{array}$ \\
\hline
\end{tabular}


Table A8. Breakdown of articles based on green and environmental marketing.

\begin{tabular}{|c|c|c|c|c|c|c|c|c|}
\hline Author(s) Year & Scope and Sample & Sample Size & Respondents & Related Theory & Variables & Study Purpose & Gap and Research Problem & Results and Outcome \\
\hline Jabbour [296] & Industrial sector & 95 & Managers & - & $\begin{array}{l}\text { Environmental training } \\
\text { constructs and environmental } \\
\text { management maturity. }\end{array}$ & $\begin{array}{l}\text { Analyzed the relationship } \\
\text { between environmental } \\
\text { training and } \\
\text { environmental } \\
\text { management maturity. }\end{array}$ & $\begin{array}{l}\text { There is a need to investigate } \\
\text { which is environmental } \\
\text { training with environmental } \\
\text { management maturity due to } \\
\text { the importance of } \\
\text { environmental issues? }\end{array}$ & $\begin{array}{l}\text { Results of this paper found that environmental training } \\
\text { had a positive influence on environmental management } \\
\text { maturity. }\end{array}$ \\
\hline $\begin{array}{l}\text { De Giovanni and } \\
\text { Esposito Vinzi [290] }\end{array}$ & $\begin{array}{l}\text { Manufacturing } \\
\text { company }\end{array}$ & 178 firms & Managers & $\begin{array}{c}\text { Supply } \\
\text { chain theory }\end{array}$ & $\begin{array}{l}\text { Firm's Green Attitude, Green } \\
\text { Supply Chain Management, } \\
\text { Firm's Environmental and } \\
\text { Economic Performance. }\end{array}$ & $\begin{array}{l}\text { Examined the influence of } \\
\text { external and internal of } \\
\text { environmental } \\
\text { management on firms' } \\
\text { performance. }\end{array}$ & $\begin{array}{l}\text { There is a lack in previous } \\
\text { studies regarding empirical } \\
\text { study related to external and } \\
\text { internal of environmental } \\
\text { management and firms' } \\
\text { performance }\end{array}$ & $\begin{array}{l}\text { Results of this paper found that the European Union's } \\
\text { Enissions Trading System (ETSS should focus on } \\
\text { internal Environmental Management, Internal } \\
\text { environmental practices improve economic } \\
\text { performance, and Supplier collaboration can slightly } \\
\text { affect firms' performance. }\end{array}$ \\
\hline $\begin{array}{l}\text { Molina-Azorín, } \\
\text { Tarí [297] }\end{array}$ & Spanish hotel & 355 & hotels' managers & Agency theory & $\begin{array}{l}\text { Quality performance, } \\
\text { Environmental performance, } \\
\text { Differentiation competitive } \\
\text { advantage and Costs } \\
\text { competitive advantage. }\end{array}$ & $\begin{array}{l}\text { The main objective of this } \\
\text { article is to explore the } \\
\text { relationship between } \\
\text { quality and environmental } \\
\text { management and the } \\
\text { competitive advantage. }\end{array}$ & $\begin{array}{l}\text { Most past papers have } \\
\text { investigated the quality and } \\
\text { environmental problems } \\
\text { separately; there are few } \\
\text { examples of previous papers } \\
\text { regarding quality and } \\
\text { environmental management } \\
\text { simultaneously. }\end{array}$ & $\begin{array}{l}\text { Outcomes of this article found that there are } \\
\text { relationships between quality and environmental } \\
\text { management and quality and environmental } \\
\text { management with competitive advantage based on } \\
\text { costs and differentiation items. }\end{array}$ \\
\hline $\begin{array}{l}\text { Martínez-Martínez } \\
\text { et al. [291] }\end{array}$ & Hospitality sector & 87 companies & $\begin{array}{l}\text { CEO or owner of } \\
\text { every business }\end{array}$ & - & $\begin{array}{l}\text { Socialisation, Externalisation, } \\
\text { Combination, Internalisation } \\
\text { and business performance. }\end{array}$ & $\begin{array}{l}\text { Investigated the role of } \\
\text { SECL model mediated } \\
\text { between the } \\
\text { environmental knowledge } \\
\text { and organizational } \\
\text { performance. }\end{array}$ & $\begin{array}{l}\text { Need to update and reuse the } \\
\text { knowledge of the } \\
\text { environmental in recent } \\
\text { coming years. }\end{array}$ & $\begin{array}{l}\text { Findings of this paper showed that time is an important } \\
\text { factor for implementation of the SECI model in } \\
\text { organizations operating. }\end{array}$ \\
\hline Gotschol et al. [298] & Firms & 240 & Managers & - & $\begin{array}{l}\text { Green production, GSCM, } \\
\text { environmental performance } \\
\text { and economic performance. }\end{array}$ & $\begin{array}{l}\text { The objective of this study } \\
\text { is to examine the } \\
\text { relationship between } \\
\text { environmental } \\
\text { management and } \\
\text { economic performance. } \\
\text { This paper investigates } \\
\text { whether environmental } \\
\text { management is an } \\
\text { economically sustainable } \\
\text { business }\end{array}$ & $\begin{array}{l}\text { Due to fails in most previous } \\
\text { studies there is a need to } \\
\text { examine the relationship } \\
\text { between environmental } \\
\text { management and economic } \\
\text { performance. }\end{array}$ & $\begin{array}{l}\text { Findings of this paper showed that environmental } \\
\text { management had a positive relationship with economic } \\
\text { performance as second order target. }\end{array}$ \\
\hline Jabbour et al. [292] & $\begin{array}{l}\text { Brazilian } \\
\text { automotive } \\
\text { companies }\end{array}$ & 75 & $\begin{array}{l}\text { Production/operations } \\
\text { managers }\end{array}$ & None & $\begin{array}{l}\text { Human resources, operational } \\
\text { performance, environmental } \\
\text { management and lean } \\
\text { manufacturing. }\end{array}$ & $\begin{array}{l}\text { The main objective of this } \\
\text { paper is to examine the } \\
\text { impact of environmental } \\
\text { management on } \\
\text { operational performance } \\
\text { by incorporating of human } \\
\text { resource and lean } \\
\text { manufacturing. }\end{array}$ & $\begin{array}{l}\text { There are no studies related to } \\
\text { environmental management, } \\
\text { operational performance, } \\
\text { human resources and lean } \\
\text { manufacturing. }\end{array}$ & $\begin{array}{l}\text { Results of this paper demonstrated that human } \\
\text { resources had a significant relationship with } \\
\text { environmental management, lean manufacturing } \\
\text { influencee on environmental managemente compared } \\
\text { with operational performance and there was a positive } \\
\text { relationship between environmental management and } \\
\text { operational performance. }\end{array}$ \\
\hline $\begin{array}{l}\text { Haimohammad } \\
\text { et al. [299] }\end{array}$ & $\begin{array}{c}\text { Canadian } \\
\text { manufacturing } \\
\text { plants }\end{array}$ & 85 & Managers & $\begin{array}{l}\text { Natural } \\
\text { resource-based } \\
\text { view (NRBV) }\end{array}$ & $\begin{array}{l}\text { Supply management, Lean } \\
\text { management, Environmental } \\
\text { practices, Environmental } \\
\text { Performance, Plant size and } \\
\text { Importance of environmental } \\
\text { issues. }\end{array}$ & $\begin{array}{l}\text { The main objective of this } \\
\text { study is to propose a } \\
\text { framework for relationship } \\
\text { among environmental } \\
\text { practices, supply and lean } \\
\text { management and } \\
\text { environmental } \\
\text { performance. }\end{array}$ & $\begin{array}{l}\text { Past studies emphasized the } \\
\text { importance of lean and supply } \\
\text { management as the } \\
\text { determinants of environmental } \\
\text { performance. }\end{array}$ & $\begin{array}{l}\text { Results of this paper found that the impact of supply } \\
\text { managagenent and lean management increased } \\
\text { environmental performance by mediating the role of } \\
\text { environmental practices. }\end{array}$ \\
\hline
\end{tabular}


Table A8. Breakdown of articles based on green and environmental marketing.

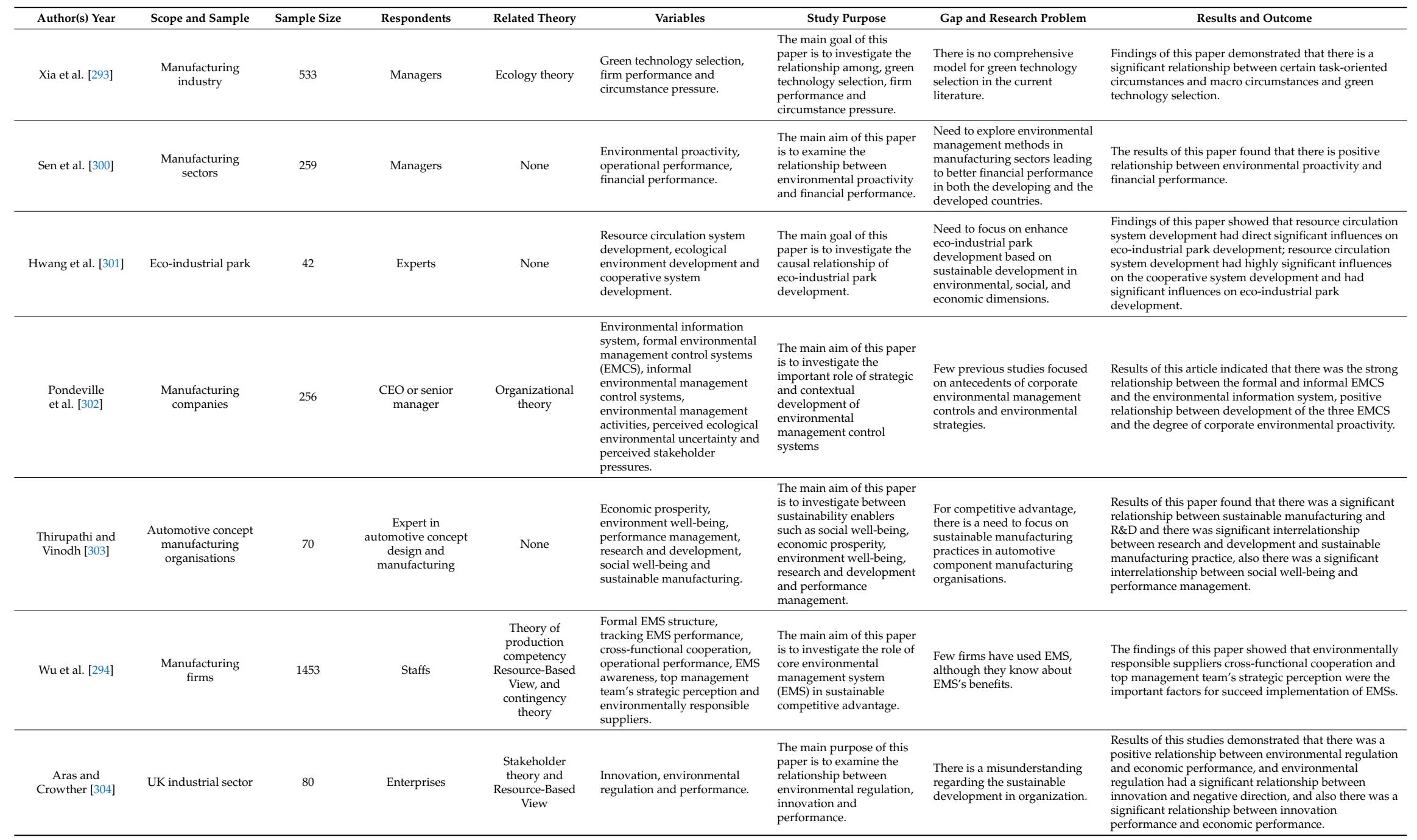


Table A8. Breakdown of articles based on green and environmental marketing.

\begin{tabular}{|c|c|c|c|c|c|c|c|c|}
\hline Author(s) Year & Scope and Sample & Sample Size & Respondents & Related Theory & Variables & Study Purpose & Gap and Research Problem & Results and Outcome \\
\hline $\begin{array}{l}\text { Bagur-Femenias } \\
\quad \text { et al. [305] }\end{array}$ & $\begin{array}{l}\text { Small service } \\
\text { companies }\end{array}$ & 448 & Managers & $\begin{array}{l}\text { Stakeholder } \\
\text { theory and } \\
\text { Resource-Based } \\
\text { View }\end{array}$ & $\begin{array}{l}\text { Environmental pressure, } \\
\text { adoption of environmental } \\
\text { practices, operational } \\
\text { performance, competitiveness } \\
\text { and firm performance. }\end{array}$ & $\begin{array}{l}\text { The main goal of this paper is } \\
\text { to examine the influence of the } \\
\text { practices of decision to adopt } \\
\text { environmental practices in } \\
\text { small service companies. }\end{array}$ & $\begin{array}{l}\text { It is important for the service } \\
\text { industry to emphasize } \\
\text { environmental practices. }\end{array}$ & $\begin{array}{l}\text { Results of this article indicated that legal environmental } \\
\text { and organizations related to the company location were } \\
\text { the main incentive to adopt environmental practices, } \\
\text { also there was a direct and positivive relationship } \\
\text { between adoption of environmental practices, } \\
\text { competitiveness and improvement of operational } \\
\text { performance. }\end{array}$ \\
\hline De Giovanni [306] & Italian firms & 240 & Top-level executives & $\begin{array}{l}\text { Stakeholder } \\
\text { theory }\end{array}$ & $\begin{array}{l}\text { External environmental } \\
\text { management, internal } \\
\text { environmental management, } \\
\text { environmental performance, } \\
\text { economic performance and } \\
\text { social performance. }\end{array}$ & $\begin{array}{l}\text { The purpose of this paper is to } \\
\text { examine the influence of } \\
\text { external and internal } \\
\text { environmental management } \\
\text { on economic, social and } \\
\text { environmental performance. }\end{array}$ & $\begin{array}{l}\text { Nowadays, focusing on } \\
\text { environmental management is } \\
\text { important for firms regarding } \\
\text { society. }\end{array}$ & 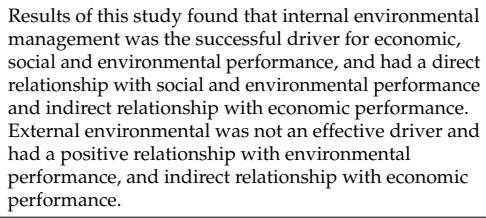 \\
\hline Kim and Lee [307] & $\begin{array}{l}\text { Korean logistics and } \\
\text { manufacturing } \\
\text { companies }\end{array}$ & 168 & $\begin{array}{l}\text { logistics MBA } \\
\text { program and } \\
\text { Logistics CEO }\end{array}$ & $\begin{array}{l}\text { Stakeholder } \\
\text { theory and RBV }\end{array}$ & $\begin{array}{l}\text { Stakeholder pressure, } \\
\text { eco-oriented culture and } \\
\text { environmental logistics } \\
\text { practices. }\end{array}$ & $\begin{array}{l}\text { The main objective of this } \\
\text { paper is o explore the } \\
\text { relationship between } \\
\text { environmental logistics } \\
\text { practice, eco-coluture and } \\
\text { stakeholders pressure. }\end{array}$ & $\begin{array}{l}\text { Little attention has been paid to } \\
\text { relationship between } \\
\text { environmental concern, } \\
\text { eco-culture and stakeholders } \\
\text { pressure. }\end{array}$ & $\begin{array}{l}\text { Results of this study found that there was a significant } \\
\text { relationshiph between stakeholders' pressure and } \\
\text { environmental logistics practice and the mediating } \\
\text { impact of eco-culture, and eco-culture full mediated the } \\
\text { relationshipip between stakeholders's pressure and } \\
\text { environmental logistics practice. }\end{array}$ \\
\hline $\begin{array}{l}\text { Wiengarten } \\
\text { et al. [308] }\end{array}$ & $\begin{array}{l}\text { Manufacturing } \\
\text { organizations }\end{array}$ & 522 & Plant managers & None & $\begin{array}{l}\text { Investments in quality } \\
\text { practices, investments in lean } \\
\text { practices, investments in } \\
\text { environmental practices and } \\
\text { operational supply chain } \\
\text { performance. }\end{array}$ & $\begin{array}{l}\text { The main objective of this } \\
\text { article is to examine the } \\
\text { relationship between } \\
\text { environmental, quality and } \\
\text { lean practices within the } \\
\text { supply chain. }\end{array}$ & $\begin{array}{l}\text { Need for more studies regarding } \\
\text { the relationship between } \\
\text { environmental, quality and lean } \\
\text { practices in the context of SC. }\end{array}$ & $\begin{array}{l}\text { Results of this paper demonstrated that quality, lean } \\
\text { and environmental practices increased operational SC } \\
\text { performance by incorororating pollution prevention, } \\
\text { waste reduction, ISO } 14001 \text { and materials recycling. }\end{array}$ \\
\hline $\begin{array}{c}\text { Yu and } \\
\text { Ramanathan [295] }\end{array}$ & $\begin{array}{c}\text { Manufacturing } \\
\text { firms }\end{array}$ & 167 & $\begin{array}{l}\text { Manufacturing } \\
\text { managers }\end{array}$ & $\begin{array}{l}\text { Stakeholder } \\
\text { theory }\end{array}$ & $\begin{array}{l}\text { Stakeholder pressures, internal } \\
\text { green management, green } \\
\text { product/process design and } \\
\text { environmental performance. }\end{array}$ & $\begin{array}{l}\text { The main purpose of this } \\
\text { paper is to explore This study } \\
\text { explores stakeholder pressures, } \\
\text { internal green management, } \\
\text { green product/process design } \\
\text { and environmental } \\
\text { performance. }\end{array}$ & $\begin{array}{l}\text { There is a need for more study of } \\
\text { relationships among stakeholder } \\
\text { pressures, internal green } \\
\text { management, green } \\
\text { product/ process design and } \\
\text { environmental performance. }\end{array}$ & $\begin{array}{l}\text { Findings of this study showed that stakeholder } \\
\text { pressures had a positive and significant influence on } \\
\text { internal green management and there was a signifificant } \\
\text { and positive relationship between internal green } \\
\text { management and green product / process design. Two } \\
\text { green operations practices had a positive and significant } \\
\text { relationshhip with environmental performance. }\end{array}$ \\
\hline $\begin{array}{l}\text { Vinodh and } \\
\text { Joy [309] }\end{array}$ & SMEs & 50 & Managers & None & $\begin{array}{l}\text { Economic sustainability, } \\
\text { environmental sustainability } \\
\text { and social sustainability. }\end{array}$ & $\begin{array}{l}\text { The main objective of this } \\
\text { paper is to explore the } \\
\text { relationshipp between three } \\
\text { main aspects of sustainable } \\
\text { development including } \\
\text { economic, social and } \\
\text { environmental sustainability. }\end{array}$ & $\begin{array}{l}\text { Although sustainable } \\
\text { manufacturing has improved, } \\
\text { few previous studies have } \\
\text { focused on the three main } \\
\text { dimensions of sustainable } \\
\text { development. }\end{array}$ & $\begin{array}{l}\text { Results of this study showed that environmental, } \\
\text { economic and social sustainability were important for } \\
\text { development of sustainability in manufacturing. }\end{array}$ \\
\hline $\begin{array}{l}\text { Hajmohammad and } \\
\text { Vachon [310] }\end{array}$ & Canadian plants & 251 & Plant managers & $\begin{array}{l}\text { Organizational } \\
\text { support theory }\end{array}$ & $\begin{array}{l}\text { Safety practices, safety } \\
\text { performance, environmental } \\
\text { practices, environmental } \\
\text { performance and financial } \\
\text { performance. }\end{array}$ & $\begin{array}{l}\text { The main goal of this study is } \\
\text { to explore the direct and } \\
\text { indirect influence of } \\
\text { sustainable development on } \\
\text { firm performance by involving } \\
\text { of safety environmental } \\
\text { culture. }\end{array}$ & $\begin{array}{l}\text { There are limitations of the } \\
\text { operations management } \\
\text { literature to showing which } \\
\text { managerial attention to } \\
\text { employee safety actually } \\
\text { improves environmental and } \\
\text { financial performance. } \\
\end{array}$ & $\begin{array}{l}\text { Findings of this paper showed that safety culture had a } \\
\text { relationship with safety, environmental and financial } \\
\text { performance, and there was a relationship between } \\
\text { safety culture and safety and environmental } \\
\text { performance mediated by the level of implementing } \\
\text { safety and environmental practices within plants. }\end{array}$ \\
\hline $\begin{array}{l}\text { Benitez-Amado } \\
\text { et al. [311] }\end{array}$ & Large Spanish firms & 63 & Managers & $\begin{array}{l}\text { Theory of } \\
\text { dynamic and } \\
\text { operational } \\
\text { capabilities }\end{array}$ & $\begin{array}{l}\text { IT infrastructure capability, } \\
\text { talent management, } \\
\text { operational environmental } \\
\text { sustainability, firm } \\
\text { performance, firm size, } \\
\text { industry and quality } \\
\text { management. }\end{array}$ & $\begin{array}{l}\text { The main purpose of this } \\
\text { paper is to investigate the } \\
\text { influence of talent } \\
\text { management and technology } \\
\text { management on operational } \\
\text { environmental sustainability. }\end{array}$ & $\begin{array}{l}\text { Few attentions have been paid to } \\
\text { talent management in } \\
\text { relationship information } \\
\text { technology and environmental } \\
\text { sustainability. }\end{array}$ & $\begin{array}{l}\text { Findings of this paper showed that IT infrastructure } \\
\text { enhancing the talent management and can be an enabler } \\
\text { for operational environmental sustainability to increase } \\
\text { firm performance. }\end{array}$ \\
\hline
\end{tabular}


Table A8. Breakdown of articles based on green and environmental marketing.

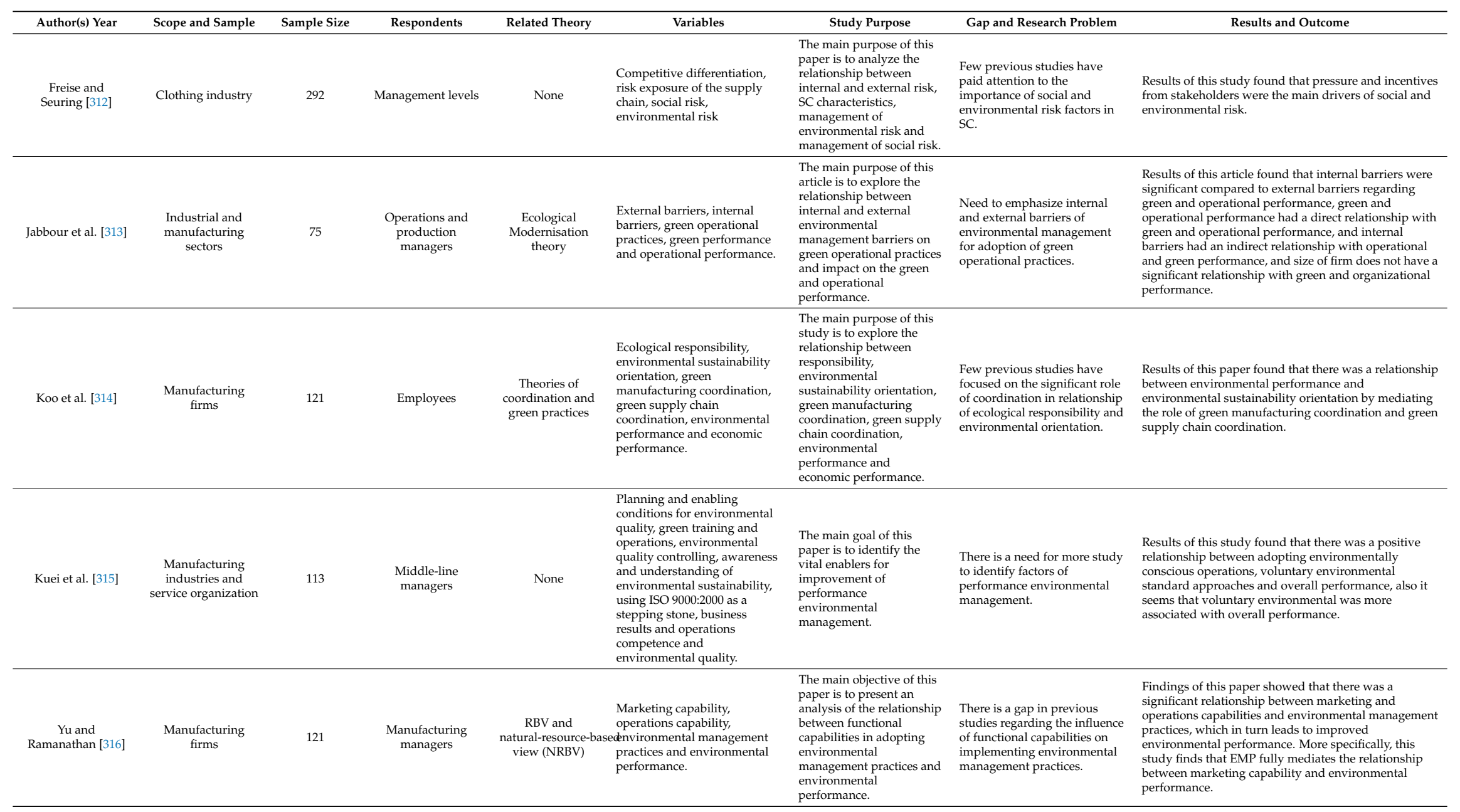




\section{References}

1. Pathak, P.; Srivastava, R.R.; Ojasvi. Assessment of legislation and practices for the sustainable management of waste electrical and electronic equipment in India. Renew. Sustain. Energy Rev. 2017, 78, 220-232. [CrossRef]

2. Cucchiella, F.; D'Adamo, I.; Gastaldi, M. Sustainable management of waste-to-energy facilities. Renew. Sustain. Energy Rev. 2014, 33, 719-728. [CrossRef]

3. Chong, Y.T.; Teo, K.M.; Tang, L.C. A lifecycle-based sustainability indicator framework for waste-to-energy systems and a proposed metric of sustainability. Renew. Sustain. Energy Rev. 2016, 56, 797-809. [CrossRef]

4. Chien Bong, C.P.; Ho, W.S.; Hashim, H.; Lim, J.S.; Ho, C.S.; Peng Tan, W.S.; Lee, C.T. Review on the renewable energy and solid waste management policies towards biogas development in Malaysia. Renew. Sustain. Energy Rev. 2017, 70, 988-998. [CrossRef]

5. Bossink, B.A.G. Demonstrating sustainable energy: A review based model of sustainable energy demonstration projects. Renew. Sustain. Energy Rev. 2017, 77, 1349-1362. [CrossRef]

6. Vidadili, N.; Suleymanov, E.; Bulut, C.; Mahmudlu, C. Transition to renewable energy and sustainable energy development in Azerbaijan. Renew. Sustain. Energy Rev. 2017, 80, 1153-1161. [CrossRef]

7. Rostami, R.; Khoshnava, S.M.; Lamit, H.; Streimikiene, D.; Mardani, A. An overview of Afghanistan's trends toward renewable and sustainable energies. Renew. Sustain. Energy Rev. 2017, 76, 1440-1464. [CrossRef]

8. Mardani, A.; Zavadskas, E.K.; Khalifah, Z.; Zakuan, N.; Jusoh, A.; Nor, K.M.; Khoshnoudi, M. A review of multi-criteria decision-making applications to solve energy management problems: Two decades from 1995 to 2015. Renew. Sustain. Energy Rev. 2017, 71, 216-256. [CrossRef]

9. Cucchiella, F.; D'Adamo, I.; Gastaldi, M.; Koh, S.C.L.; Rosa, P. A comparison of environmental and energetic performance of European countries: A sustainability index. Renew. Sustain. Energy Rev. 2017, 78, 401-413. [CrossRef]

10. Niesten, E.; Jolink, A.; Lopes de Sousa Jabbour, A.B.; Chappin, M.; Lozano, R. Sustainable collaboration: The impact of governance and institutions on sustainable performance. J. Clean. Prod. 2017, 155, 1-6. [CrossRef]

11. Morioka, S.N.; Carvalho, M.M. Measuring sustainability in practice: Exploring the inclusion of sustainability into corporate performance systems in Brazilian case studies. J. Clean. Prod. 2016, 136, 123-133. [CrossRef]

12. Byrka, K.; Jȩdrzejewski, A.; Sznajd-Weron, K.; Weron, R. Difficulty is critical: The importance of social factors in modeling diffusion of green products and practices. Renew. Sustain. Energy Rev. 2016, 62, 723-735. [CrossRef]

13. Hast, A.; Syri, S.; Jokiniemi, J.; Huuskonen, M.; Cross, S. Review of green electricity products in the United Kingdom, Germany and Finland. Renew. Sustain. Energy Rev. 2015, 42, 1370-1384. [CrossRef]

14. De Medeiros, J.F.; Ribeiro, J.L.D. Environmentally sustainable innovation: Expected attributes in the purchase of green products. J. Clean. Prod. 2017, 142, 240-248. [CrossRef]

15. De Angelis, M.; Adıgüzel, F.; Amatulli, C. The role of design similarity in consumers' evaluation of new green products: An investigation of luxury fashion brands. J. Clean. Prod. 2017, 141, 1515-1527. [CrossRef]

16. Lee, C.T.; Hashim, H.; Ho, C.S.; Fan, Y.V.; Klemeš, J.J. Sustaining the low-carbon emission development in Asia and beyond: Sustainable energy, water, transportation and low-carbon emission technology. J. Clean. Prod. 2017, 146, 1-13. [CrossRef]

17. Charoenkit, S.; Kumar, S. Environmental sustainability assessment tools for low carbon and climate resilient low income housing settlements. Renew. Sustain. Energy Rev. 2014, 38, 509-525. [CrossRef]

18. Aldossary, N.A.; Rezgui, Y.; Kwan, A. Consensus-based low carbon domestic design framework for sustainable homes. Renew. Sustain. Energy Rev. 2015, 51, 417-432. [CrossRef]

19. Moscardo, G. Building Excellence in Sustainable Tourism: 15 years of Building Excellence in Sustainable Tourism Education Network (BEST EN) practice. J. Clean. Prod. 2016, 111, 538-539. [CrossRef]

20. Budeanu, A.; Miller, G.; Moscardo, G.; Ooi, C.-S. Sustainable tourism, progress, challenges and opportunities: An introduction. J. Clean. Prod. 2016, 111, 285-294. [CrossRef]

21. Mathew, P.V.; Sreejesh, S. Impact of responsible tourism on destination sustainability and quality of life of community in tourism destinations. J. Hosp. Tour. Manag. 2017, 31, 83-89. [CrossRef]

22. Dedeke, A. Creating sustainable tourism ventures in protected areas: An actor-network theory analysis. Tour. Manag. 2017, 61, 161-172. [CrossRef] 
23. Shuja, J.; Gani, A.; Shamshirband, S.; Ahmad, R.W.; Bilal, K. Sustainable Cloud Data Centers: A survey of enabling techniques and technologies. Renew. Sustain. Energy Rev. 2016, 62, 195-214. [CrossRef]

24. Luthra, S.; Kumar, S.; Garg, D.; Haleem, A. Barriers to renewable/sustainable energy technologies adoption: Indian perspective. Renew. Sustain. Energy Rev. 2015, 41, 762-776. [CrossRef]

25. Chugh, R.; Wibowo, S.; Grandhi, S. Environmentally sustainable Information and Communication Technology usage: Awareness and practices of Indian Information and Communication Technology professionals. J. Clean. Prod. 2016, 131, 435-446. [CrossRef]

26. Kauffman, R.J.; Riggins, F.J. Information and communication technology and the sustainability of microfinance. Electron. Commer. Res. Appl. 2012, 11, 450-468. [CrossRef]

27. Jilcha, K.; Kitaw, D. Industrial occupational safety and health innovation for sustainable development. Eng. Sci. Technol. Int. J. 2017, 20, 372-380. [CrossRef]

28. Wedam, E.A.; Sanyare, F.N. Health care financing and sustainability: A study of current conceptual dialectics in Ghana. World Dev. Perspect. 2017, 5, 47-55. [CrossRef]

29. Lehner, M.; Mont, O.; Heiskanen, E. Nudging-A promising tool for sustainable consumption behaviour? J. Clean. Prod. 2016, 134, 166-177. [CrossRef]

30. Grandia, J. Finding the missing link: Examining the mediating role of sustainable public procurement behaviour. J. Clean. Prod. 2016, 124, 183-190. [CrossRef]

31. Chen, H.H.; Chen, S.; Lan, Y. Attaining a sustainable competitive advantage in the smart grid industry of China using suitable open innovation intermediaries. Renew. Sustain. Energy Rev. 2016, 62, 1083-1091. [CrossRef]

32. Marcon, A.; de Medeiros, J.F.; Ribeiro, J.L.D. Innovation and environmentally sustainable economy: Identifying the best practices developed by multinationals in Brazil. J. Clean. Prod. 2017, 160, 83-97. [CrossRef]

33. Horng, J.-S.; Liu, C.-H.; Chou, S.-F.; Tsai, C.-Y.; Chung, Y.-C. From innovation to sustainability: Sustainability innovations of eco-friendly hotels in Taiwan. Int. J. Hosp. Manag. 2017, 63, 44-52. [CrossRef]

34. Farhidi, F. Solar impacts on the sustainability of economic growth. Renew. Sustain. Energy Rev. 2017, 77, 440-450. [CrossRef]

35. Ocetkiewicz, I.; Tomaszewska, B.; Mróz, A. Renewable energy in education for sustainable development. The Polish experience. Renew. Sustain. Energy Rev. 2017, 80, 92-97. [CrossRef]

36. Shaikh, P.H.; Nor, N.B.M.; Sahito, A.A.; Nallagownden, P.; Elamvazuthi, I.; Shaikh, M.S. Building energy for sustainable development in Malaysia: A review. Renew. Sustain. Energy Rev. 2017, 75, 1392-1403. [CrossRef]

37. González, M.O.A.; Gonçalves, J.S.; Vasconcelos, R.M. Sustainable development: Case study in the implementation of renewable energy in Brazil. J. Clean. Prod. 2017, 142, 461-475. [CrossRef]

38. Anand, A.; Khan, R.A.; Wani, M.F. Development of a sustainability risk assessment index of a mechanical system at conceptual design stage. J. Clean. Prod. 2016, 139, 258-266. [CrossRef]

39. Wu, J.; Pu, G.; Ma, Q.; Qi, H.; Wang, R. Quantitative environmental risk assessment for the iron and steel industrial symbiosis network. J. Clean. Prod. 2017, 157, 106-117. [CrossRef]

40. Hou, D.; Qi, S.; Zhao, B.; Rigby, M.; O'Connor, D. Incorporating life cycle assessment with health risk assessment to select the 'greenest' cleanup level for Pb contaminated soil. J. Clean. Prod. 2017, 162, 1157-1168. [CrossRef]

41. Hashemkhani Zolfani, S.; Pourhossein, M.; Yazdani, M.; Kazimieras Zavadskas, E. Evaluating construction projects of hotels based on environmental sustainability with MCDM framework. Alex. Eng. J. 2017, in press. [CrossRef]

42. Lam, J.S.L.; Lai, K. Developing environmental sustainability by ANP-QFD approach: The case of shipping operations. J. Clean. Prod. 2015, 105, 275-284. [CrossRef]

43. Govindan, K.; Madan Shankar, K.; Kannan, D. Sustainable material selection for construction industry-A hybrid multi criteria decision making approach. Renew. Sustain. Energy Rev. 2016, 55, 1274-1288. [CrossRef]

44. Khoshnava, S.M.; Rostami, R.; Valipour, A.; Ismail, M.; Rahmat, A.R. Rank of green building material criteria based on the three pillars of sustainability using the hybrid multi criteria decision making method. J. Clean. Prod. 2016, in press. [CrossRef]

45. Tsagarakis, K.P.; Bounialetou, F.; Gillas, K.; Profylienou, M.; Pollaki, A.; Zografakis, N. Tourists' attitudes for selecting accommodation with investments in renewable energy and energy saving systems. Renew. Sustain. Energy Rev. 2011, 15, 1335-1342. [CrossRef] 
46. Juvan, E.; Dolnicar, S. Measuring environmentally sustainable tourist behaviour. Ann. Tour. Res. 2016, 59, 30-44. [CrossRef]

47. López-Sánchez, Y.; Pulido-Fernández, J.I. In search of the pro-sustainable tourist: A segmentation based on the tourist "sustainable intelligence". Tour. Manag. Perspect. 2016, 17, 59-71. [CrossRef]

48. Su, L.; Swanson, S.R. The effect of destination social responsibility on tourist environmentally responsible behavior: Compared analysis of first-time and repeat tourists. Tour. Manag. 2017, 60, 308-321. [CrossRef]

49. Budzianowski, W.M. High-value low-volume bioproducts coupled to bioenergies with potential to enhance business development of sustainable biorefineries. Renew. Sustain. Energy Rev. 2017, 70, 793-804. [CrossRef]

50. Caldera, H.T.S.; Desha, C.; Dawes, L. Exploring the role of lean thinking in sustainable business practice: A systematic literature review. J. Clean. Prod. 2017, 167, 1546-1565. [CrossRef]

51. Retamal, M. Product-service systems in Southeast Asia: Business practices and factors influencing environmental sustainability. J. Clean. Prod. 2017, 143, 894-903. [CrossRef]

52. Kianpour, K.; Jusoh, A.; Mardani, A.; Streimikiene, D.; Cavallaro, F.; Nor, K.M.; Zavadskas, E. Factors Influencing Consumers' Intention to Return the End of Life Electronic Products through Reverse Supply Chain Management for Reuse, Repair and Recycling. Sustainability 2017, 9, 1657. [CrossRef]

53. Jin, M.; Tang, R.; Ji, Y.; Liu, F.; Gao, L.; Huisingh, D. Impact of advanced manufacturing on sustainability: An overview of the special volume on advanced manufacturing for sustainability and low fossil carbon emissions. J. Clean. Prod. 2017, 161, 69-74. [CrossRef]

54. Helleno, A.L.; de Moraes, A.J.I.; Simon, A.T. Integrating sustainability indicators and Lean Manufacturing to assess manufacturing processes: Application case studies in Brazilian industry. J. Clean. Prod. 2017, 153, 405-416. [CrossRef]

55. Giret, A.; Trentesaux, D.; Salido, M.A.; Garcia, E.; Adam, E. A holonic multi-agent methodology to design sustainable intelligent manufacturing control systems. J. Clean. Prod. 2017, 167, 1370-1386. [CrossRef]

56. Rauch, E.; Dallasega, P.; Matt, D.T. Sustainable production in emerging markets through Distributed Manufacturing Systems (DMS). J. Clean. Prod. 2016, 135, 127-138. [CrossRef]

57. Chen, H.-G.; Zhang, Y.H.P. New biorefineries and sustainable agriculture: Increased food, biofuels, and ecosystem security. Renew. Sustain. Energy Rev. 2015, 47, 117-132. [CrossRef]

58. Mekhilef, S.; Faramarzi, S.Z.; Saidur, R.; Salam, Z. The application of solar technologies for sustainable development of agricultural sector. Renew. Sustain. Energy Rev. 2013, 18, 583-594. [CrossRef]

59. Ozturk, I. The dynamic relationship between agricultural sustainability and food-energy-water poverty in a panel of selected Sub-Saharan African Countries. Energy Policy 2017, 107, 289-299. [CrossRef]

60. Wang, X.; Li, Z.; Long, P.; Yan, L.; Gao, W.; Chen, Y.; Sui, P. Sustainability evaluation of recycling in agricultural systems by emergy accounting. Resour. Conserv. Recycl. 2017, 117, 114-124. [CrossRef]

61. Hussain, M.; Khan, M.; Al-Aomar, R. A framework for supply chain sustainability in service industry with Confirmatory Factor Analysis. Renew. Sustain. Energy Rev. 2016, 55, 1301-1312. [CrossRef]

62. Espinoza Pérez, A.T.; Camargo, M.; Narváez Rincón, P.C.; Alfaro Marchant, M. Key challenges and requirements for sustainable and industrialized biorefinery supply chain design and management: A bibliographic analysis. Renew. Sustain. Energy Rev. 2017, 69, 350-359. [CrossRef]

63. Raut, R.D.; Narkhede, B.; Gardas, B.B. To identify the critical success factors of sustainable supply chain management practices in the context of oil and gas industries: ISM approach. Renew. Sustain. Energy Rev. 2017, 68, 33-47. [CrossRef]

64. Fritz, M.M.C.; Schöggl, J.-P.; Baumgartner, R.J. Selected sustainability aspects for supply chain data exchange: Towards a supply chain-wide sustainability assessment. J. Clean. Prod. 2017, 141, 587-607. [CrossRef]

65. Živković, S.B.; Veljković, M.V.; Banković-Ilić, I.B.; Krstić, I.M.; Konstantinović, S.S.; Ilić, S.B.; Avramović, J.M.; Stamenković, O.S.; Veljković, V.B. Technological, technical, economic, environmental, social, human health risk, toxicological and policy considerations of biodiesel production and use. Renew. Sustain. Energy Rev. 2017, 79, 222-247. [CrossRef]

66. Cambero, C.; Sowlati, T. Assessment and optimization of forest biomass supply chains from economic, social and environmental perspectives-A review of literature. Renew. Sustain. Energy Rev. 2014, 36, 62-73. [CrossRef]

67. Pashaei Kamali, F.; Meuwissen, M.P.M.; de Boer, I.J.M.; van Middelaar, C.E.; Moreira, A.; Oude Lansink, A.G.J.M. Evaluation of the environmental, economic, and social performance of soybean farming systems in southern Brazil. J. Clean. Prod. 2017, 142, 385-394. [CrossRef] 
68. Njoh, A.J. The SWOT model's utility in evaluating energy technology: Illustrative application of a modified version to assess the sawdust cookstove's sustainability in Sub-Saharan Africa. Renew. Sustain. Energy Rev. 2017, 69, 313-323. [CrossRef]

69. Drews, S.; van den Bergh, J.C.J.M. Public views on economic growth, the environment and prosperity: Results of a questionnaire survey. Glob. Environ. Chang. 2016, 39, 1-14. [CrossRef]

70. Özokcu, S.; Özdemir, Ö. Economic growth, energy, and environmental Kuznets curve. Renew. Sustain. Energy Rev. 2017, 72, 639-647. [CrossRef]

71. Moretti, M.; Djomo, S.N.; Azadi, H.; May, K.; De Vos, K.; Van Passel, S.; Witters, N. A systematic review of environmental and economic impacts of smart grids. Renew. Sustain. Energy Rev. 2017, 68 Pt 2, 888-898. [CrossRef]

72. Liu, X.; Liu, G.; Yang, Z.; Chen, B.; Ulgiati, S. Comparing national environmental and economic performances through emergy sustainability indicators: Moving environmental ethics beyond anthropocentrism toward ecocentrism. Renew. Sustain. Energy Rev. 2016, 58, 1532-1542. [CrossRef]

73. Bartlett, R.V.; Baber, W.F. Ethics and environmental policy in democratic governance: John Rawls, public reason, and normative precommitment. Public Integr. 2005, 7, 219-240.

74. Añón Higón, D.; Gholami, R.; Shirazi, F. ICT and environmental sustainability: A global perspective. Telemat. Inf. 2017, 34, 85-95. [CrossRef]

75. Cook, D.; Saviolidis, N.M.; Davíðsdóttir, B.; Jóhannsdóttir, L.; Ólafsson, S. Measuring countries' environmental sustainability performance-The development of a nation-specific indicator set. Ecol. Indic. 2017, 74, 463-478. [CrossRef]

76. Gallego-Álvarez, P.I.; Ortas, P.E. Corporate environmental sustainability reporting in the context of national cultures: A quantile regression approach. Int. Bus. Rev. 2017, 26, 337-353. [CrossRef]

77. Martínez León, H.C.; Calvo-Amodio, J. Towards lean for sustainability: Understanding the interrelationships between lean and sustainability from a systems thinking perspective. J. Clean. Prod. 2017, 142 Pt 4, 4384-4402. [CrossRef]

78. Park, K.; Kremer, G.E.O. Text mining-based categorization and user perspective analysis of environmental sustainability indicators for manufacturing and service systems. Ecol. Indic. 2017, 72, 803-820. [CrossRef]

79. Shrivastava, P.; Guimarães-Costa, N. Achieving environmental sustainability: The case for multi-layered collaboration across disciplines and players. Technol. Forecast. Soc. Chang. 2017, 116, 340-346. [CrossRef]

80. Siddiqi, A.; Collins, R.D. Sociotechnical systems and sustainability: Current and future perspectives for inclusive development. Curr. Opin. Environ. Sustain. 2017, 24, 7-13. [CrossRef]

81. Soflaei, F.; Shokouhian, M.; Zhu, W. Socio-environmental sustainability in traditional courtyard houses of Iran and China. Renew. Sustain. Energy Rev. 2017, 69, 1147-1169. [CrossRef]

82. Souza, R.G.; Rosenhead, J.; Salhofer, S.P.; Valle, R.A.B.; Lins, M.P.E. Definition of sustainability impact categories based on stakeholder perspectives. J. Clean. Prod. 2015, 105, 41-51. [CrossRef]

83. Tufa, R.A. Perspectives on environmental ethics in sustainability of membrane based technologies for water and energy production. Environ. Technol. Innov. 2015, 4, 182-193. [CrossRef]

84. Toonen, H.M.; Lindeboom, H.J. Dark green electricity comes from the sea: Capitalizing on ecological merits of offshore wind power? Renew. Sustain. Energy Rev. 2015, 42, 1023-1033. [CrossRef]

85. Pearce, D.W.; Markandya, A.; Barbier, E. Blueprint for a Green Economy; Earthscan: London, UK, 1989.

86. Booth, A.L.; Skelton, N.W. Industry and government perspectives on First Nations' participation in the British Columbia environmental assessment process. Environ. Impact Assess. Rev. 2011, 31, 216-225. [CrossRef]

87. Wen, J.; Hao, Y.; Feng, G.-F.; Chang, C.-P. Does government ideology influence environmental performance? Evidence based on a new dataset. Econ. Syst. 2016, 40, 232-246. [CrossRef]

88. Howes, Y.; Gifford, R. Stable or dynamic value importance? The interaction between value endorsement level and situational differences on decision-making in environmental issues. Environm. Behav. 2009, 41, 549-582. [CrossRef]

89. Vachon, S. Green supply chain practices and the selection of environmental technologies. Int. J. Prod. Res. 2007, 45, 4357-4379. [CrossRef]

90. Kolk, A.; Mauser, A. The evolution of environmental management: From stage models to performance evaluation. Bus. Strategy Environ. 2002, 11, 14-31. [CrossRef]

91. Petulla, J.M. Environmental management in industry. J. Prof. Issues Eng. 1987, 113, 167-183. [CrossRef] 
92. Williams, A.; Kennedy, S.; Philipp, F.; Whiteman, G. Systems thinking: A review of sustainability management research. J. Clean. Prod. 2017, 148, 866-881. [CrossRef]

93. Moher, D.; Liberati, A.; Tetzlaff, J.; Altman, D.G. Preferred reporting items for systematic reviews and meta-analyses: The PRISMA statement. Ann. Intern. Med. 2009, 151, 264-269. [CrossRef] [PubMed]

94. Budgen, D.; Brereton, P. Performing systematic literature reviews in software engineering. In Proceedings of the 28th International Conference on Software Engineering, Shanghai, China, 20-28 May 2006; ACM: New York, NY, USA, 2006; pp. 1051-1052.

95. Phillips, P.J.; Newton, E.M. Meta-analysis of face recognition algorithms. In Proceedings of the Fifth IEEE International Conference on Automatic Face and Gesture Recognition, Washington, DC, USA, 21 May 2002; IEEE: Piscataway, NY, USA, 2002; pp. 235-241.

96. Liberati, A.; Altman, D.G.; Tetzlaff, J.; Mulrow, C.; Gøtzsche, P.C.; Ioannidis, J.P.; Clarke, M.; Devereaux, P.J.; Kleijnen, J.; Moher, D. The PRISMA statement for reporting systematic reviews and meta-analyses of studies that evaluate health care interventions: Explanation and elaboration. Ann. Intern. Med. 2009, 151, W65-W94. [CrossRef] [PubMed]

97. Mardani, A.; Zavadskas, E.K.; Khalifah, Z.; Zakuan, N.; Jusoh, A.; Nor, K.M.; Khoshnoudi, M. A systematic review and meta-Analysis of SWARA and WASPAS methods: Theory and applications with recent fuzzy developments. Appl. Soft Comput. 2017, 57, 265-292. [CrossRef]

98. Soheilirad, S.; Govindan, K.; Mardani, A.; Zavadskas, E.K.; Nilashi, M.; Zakuan, N. Application of data envelopment analysis models in supply chain management: A systematic review and meta-analysis. Ann. Oper. Res. 2017, in press. [CrossRef]

99. Zare, M.; Pahl, C.; Rahnama, H.; Nilashi, M.; Mardani, A.; Ibrahim, O.; Ahmadi, H. Multi-criteria decision making approach in E-learning: A systematic review and classification. Appl. Soft Comput. 2016, 45, 108-128. [CrossRef]

100. Laari, S.; Töyli, J.; Ojala, L. Supply chain perspective on competitive strategies and green supply chain management strategies. J. Clean. Prod. 2017, 141, 303-315. [CrossRef]

101. Scur, G.; Barbosa, M.E. Green supply chain management practices: Multiple case studies in the Brazilian home appliance industry. J. Clean. Prod. 2017, 141, 1293-1302. [CrossRef]

102. Sharma, V.K.; Chandna, P.; Bhardwaj, A. Green supply chain management related performance indicators in agro industry: A review. J. Clean. Prod. 2017, 141, 1194-1208. [CrossRef]

103. Tramarico, C.L.; Salomon, V.A.P.; Marins, F.A.S. Multi-criteria assessment of the benefits of a supply chain management training considering green issues. J. Clean. Prod. 2017, 142 Pt 1, 249-256. [CrossRef]

104. Xing, K.; Qian, W.; Zaman, A.U. Development of a cloud-based platform for footprint assessment in green supply chain management. J. Clean. Prod. 2016, 139, 191-203. [CrossRef]

105. Kusi-Sarpong, S.; Sarkis, J.; Wang, X. Assessing green supply chain practices in the Ghanaian mining industry: A framework and evaluation. Int. J. Prod. Econ. 2016, 181 Pt B, 325-341. [CrossRef]

106. Nagati, H.; Rebolledo, C. Supplier development efforts: The suppliers' point of view. Ind. Mark. Manag. 2013, 42, 180-188. [CrossRef]

107. Mariadoss, B.J.; Chi, T.; Tansuhaj, P.; Pomirleanu, N. Influences of Firm Orientations on Sustainable Supply Chain Management. J. Bus. Res. 2016, 69, 3406-3414. [CrossRef]

108. Youn, S.; Yang, M.G.; Hong, P.; Park, K. Strategic supply chain partnership, environmental supply chain management practices, and performance outcomes: An empirical study of Korean firms. J. Clean. Prod. 2013, 56, 121-130. [CrossRef]

109. Large, R.O.; Gimenez Thomsen, C. Drivers of green supply management performance: Evidence from Germany. J. Purch. Supply Manag. 2011, 17, 176-184. [CrossRef]

110. Lee, V.-H.; Ooi, K.-B.; Chong, A.Y.-L.; Seow, C. Creating technological innovation via green supply chain management: An empirical analysis. Expert Syst. Appl. 2014, 41, 6983-6994. [CrossRef]

111. Couto, J.; Tiago, T.; Gil, A.; Tiago, F.; Faria, S. It's hard to be green: Reverse green value chain. Environ. Res. 2016, 149, 302-313. [CrossRef] [PubMed]

112. Cheng, J.-H.; Sheu, J.-B. Inter-organizational relationships and strategy quality in green supply chains-Moderated by opportunistic behavior and dysfunctional conflict. Ind. Mark. Manag. 2012, 41, 563-572. [CrossRef] 
113. Chan, R.Y.K.; He, H.; Chan, H.K.; Wang, W.Y.C. Environmental orientation and corporate performance: The mediation mechanism of green supply chain management and moderating effect of competitive intensity. Ind. Mark. Manag. 2012, 41, 621-630. [CrossRef]

114. Hazen, B.T.; Overstreet, R.E.; Hall, D.J.; Huscroft, J.R.; Hanna, J.B. Antecedents to and outcomes of reverse logistics metrics. Ind. Mark. Manag. 2015, 46, 160-170. [CrossRef]

115. Xu, X.; Gursoy, D. Influence of sustainable hospitality supply chain management on customers' attitudes and behaviors. Int. J. Hosp. Manag. 2015, 49, 105-116. [CrossRef]

116. De Giovanni, P.; Esposito Vinzi, V. Covariance versus component-based estimations of performance in green supply chain management. Int. J. Prod. Econ. 2012, 135, 907-916. [CrossRef]

117. Esfahbodi, A.; Zhang, Y.; Watson, G. Sustainable supply chain management in emerging economies: Trade-offs between environmental and cost performance. Int. J. Prod. Econ. 2016, 181 Pt B, 350-366. [CrossRef]

118. Akamp, M.; Müller, M. Supplier management in developing countries. J. Clean. Prod. 2013, 56, 54-62. [CrossRef]

119. Kuei, C.; Madu, C.N.; Chow, W.S.; Chen, Y. Determinants and associated performance improvement of green supply chain management in China. J. Clean. Prod. 2015, 95, 163-173. [CrossRef]

120. Sancha, C.; Gimenez, C.; Sierra, V. Achieving a socially responsible supply chain through assessment and collaboration. J. Clean. Prod. 2016, 112 Pt 3, 1934-1947. [CrossRef]

121. Woo, C.; Kim, M.G.; Chung, Y.; Rho, J.J. Suppliers' communication capability and external green integration for green and financial performance in Korean construction industry. J. Clean. Prod. 2016, 112 Pt 1, 483-493. [CrossRef]

122. Laari, S.; Töyli, J.; Solakivi, T.; Ojala, L. Firm performance and customer-driven green supply chain management. J. Clean. Prod. 2016, 112 Pt 3, 1960-1970. [CrossRef]

123. Teixeira, A.A.; Jabbour, C.J.C.; de Sousa Jabbour, A.B.L.; Latan, H.; de Oliveira, J.H.C. Green training and green supply chain management: Evidence from Brazilian firms. J. Clean. Prod. 2016, 116, 170-176. [CrossRef]

124. Kumar, D.; Rahman, Z. Buyer supplier relationship and supply chain sustainability: Empirical study of Indian automobile industry. J. Clean. Prod. 2016, 131, 836-848. [CrossRef]

125. Chiou, T.-Y.; Chan, H.K.; Lettice, F.; Chung, S.H. The influence of greening the suppliers and green innovation on environmental performance and competitive advantage in Taiwan. Transp. Res. Part E Logist. Transp. Rev. 2011, 47, 822-836. [CrossRef]

126. Gavronski, I.; Klassen, R.D.; Vachon, S.; Nascimento, L.F.M.D. A resource-based view of green supply management. Transp. Res. Part E Logist. Transp. Rev. 2011, 47, 872-885. [CrossRef]

127. Yang, C.-S.; Lu, C.-S.; Haider, J.J.; Marlow, P.B. The effect of green supply chain management on green performance and firm competitiveness in the context of container shipping in Taiwan. Transp. Res. Part $E$ Logist. Transp. Rev. 2013, 55, 55-73. [CrossRef]

128. Luo, J.; Chong, A.Y.-L.; Ngai, E.W.T.; Liu, M.J. Green Supply Chain Collaboration implementation in China: The mediating role of guanxi. Transp. Res. Part E Logist. Transp. Rev. 2014, 71, 98-110. [CrossRef]

129. Dai, J.; Montabon, F.L.; Cantor, D.E. Linking rival and stakeholder pressure to green supply management: Mediating role of top management support. Transp. Res. Part E Logist. Transp. Rev. 2014, 71, 173-187. [CrossRef]

130. Jabbour, A.B.L.D.S.; Jabbour, C.J.C.; Latan, H.; Teixeira, A.A.; de Oliveira, J.H.C. Quality management, environmental management maturity, green supply chain practices and green performance of Brazilian companies with ISO 14001 certification: Direct and indirect effects. Transp. Res. Part E Logist. Transp. Rev. 2014, 67, 39-51. [CrossRef]

131. Zhu, Q.; Sarkis, J.; Lai, K. Institutional-based antecedents and performance outcomes of internal and external green supply chain management practices. J. Purch. Supply Manag. 2013, 19, 106-117. [CrossRef]

132. Caniëls, M.C.J.; Gehrsitz, M.H.; Semeijn, J. Participation of suppliers in greening supply chains: An empirical analysis of German automotive suppliers. J. Purch. Supply Manag. 2013, 19, 134-143. [CrossRef]

133. Gualandris, J.; Kalchschmidt, M. Customer pressure and innovativeness: Their role in sustainable supply chain management. J. Purch. Supply Manag. 2014, 20, 92-103. [CrossRef]

134. Gualandris, J.; Kalchschmidt, M. Developing environmental and social performance: The role of suppliers' sustainability and buyer-supplier trust. Int. J. Prod. Res. 2016, 54, 2470-2486. [CrossRef] 
135. Caniëls, M.C.J.; Cleophas, E.; Semeijn, J. Implementing green supply chain practices: An empirical investigation in the shipbuilding industry. Marit. Policy Manag. 2016, 43, 1005-1020. [CrossRef]

136. Rao, P.; Holt, D. Do green supply chains lead to competitiveness and economic performance? Int. J. Oper. Prod. Manag. 2005, 25, 898-916. [CrossRef]

137. Green, K.W.; Zelbst, P.J.; Bhadauria, V.S.; Meacham, J. Do environmental collaboration and monitoring enhance organizational performance? Ind. Manag. Data Syst. 2012, 112, 186-205. [CrossRef]

138. Lee, S.M.; Tae Kim, S.; Choi, D. Green supply chain management and organizational performance. Ind. Manag. Data Syst. 2012, 112, 1148-1180. [CrossRef]

139. Green, K.W.; Zelbst, P.J.; Meacham, J.; Bhadauria, V.S. Green supply chain management practices: Impact on performance. Supply Chain Manag. Int. J. 2012, 17, 290-305. [CrossRef]

140. Lee, V.-H.; Ooi, K.-B.; Chong, A.Y.-L.; Lin, B. A structural analysis of greening the supplier, environmental performance and competitive advantage. Prod. Plan. Control 2015, 26, 116-130. [CrossRef]

141. Villanueva-Ponce, R.; Garcia-Alcaraz, J.L.; Cortes-Robles, G.; Romero-Gonzalez, J.; Jiménez-Macías, E.; Blanco-Fernández, J. Impact of suppliers' green attributes in corporate image and financial profit: Case maquiladora industry. Int. J. Adv. Manuf. Technol. 2015, 80, 1277-1296. [CrossRef]

142. Gimenez, C.; Sierra, V. Sustainable Supply Chains: Governance Mechanisms to Greening Suppliers. J. Bus. Ethics 2013, 116, 189-203. [CrossRef]

143. Hollos, D.; Blome, C.; Foerstl, K. Does sustainable supplier co-operation affect performance? Examining implications for the triple bottom line. Int. J. Prod. Res. 2012, 50, 2968-2986. [CrossRef]

144. Abareshi, A.; Molla, A. Greening logistics and its impact on environmental performance: An absorptive capacity perspective. Int. J. Logist. Res. Appl. 2013, 16, 209-226. [CrossRef]

145. Tachizawa, E.M.; Gimenez, C.; Sierra, V. Green supply chain management approaches: Drivers and performance implications. Int. J. Oper. Prod. Manag. 2015, 35, 1546-1566. [CrossRef]

146. Hsu, C.-C.; Tan, K.-C.; Mohamad Zailani, S.H. Strategic orientations, sustainable supply chain initiatives, and reverse logistics: Empirical evidence from an emerging market. Int. J. Oper. Prod. Manag. 2016, 36, 86-110. [CrossRef]

147. Hsu, C.C.; Choon Tan, K.; Hanim Mohamad Zailani, S.; Jayaraman, V. Supply chain drivers that foster the development of green initiatives in an emerging economy. Int. J. Oper. Prod. Manag. 2013, 33, 656-688. [CrossRef]

148. Kirchoff, J.F.; Tate, W.L.; Mollenkopf, D.A. The impact of strategic organizational orientations on green supply chain management and firm performance. Int. J. Phys. Distrib.Logist. Manag. 2016, 46, 269-292. [CrossRef]

149. Pazirandeh, A.; Jafari, H. Making sense of green logistics. Int. J. Prod. Perform. Manag. 2013, 62, 889-904. [CrossRef]

150. Ateş, M.A.; Bloemhof, J.; van Raaij, E.M.; Wynstra, F. Proactive environmental strategy in a supply chain context: The mediating role of investments. Int. J. Prod. Res. 2012, 50, 1079-1095. [CrossRef]

151. Lee, S.-Y. The effects of green supply chain management on the supplier's performance through social capital accumulation. Supply Chain Manag. Int. J. 2015, 20, 42-55. [CrossRef]

152. Yu, W.; Chavez, R.; Feng, M.; Wiengarten, F. Integrated green supply chain management and operational performance. Supply Chain Manag. Int. J. 2014, 19, 683-696. [CrossRef]

153. Amann, M.; Roehrich, J.K.; Eßig, M.; Harland, C. Driving sustainable supply chain management in the public sector: The importance of public procurement in the European Union. Supply Chain Manag. Int. J. 2014, 19, 351-366. [CrossRef]

154. Gopal, P.R.C.; Thakkar, J. Sustainable supply chain practices: An empirical investigation on Indian automobile industry. Prod. Plan. Control 2016, 27, 49-64. [CrossRef]

155. Khaksar, E.; Abbasnejad, T.; Esmaeili, A.; Tamošaitienè, J. The effect of green supply chain management practices on environmental performance and competitive advantage: A case study of the cement industry. Technol. Econ. Dev. Econ. 2016, 22, 293-308. [CrossRef]

156. Burianová, L.; Paulík, J. Corporate Social Responsibility in Commercial Banking-A Case Study from the Czech Republic. J.Competitiveness 2014, 6, 50-70. [CrossRef]

157. McWilliams, A.; Siegel, D. Corporate social responsibility: A theory of the firm perspective. Acad. Manag. Rev. 2001, 26, 117-127. 
158. Gruca, T.S.; Rego, L.L. Customer Satisfaction, Cash Flow, and Shareholder Value. J. Mark. 2005, 69, 115-130. [CrossRef]

159. Fornell, C.; Mithas, S.; Morgeson, F.V., III; Krishnan, M.S. Customer satisfaction and stock prices: High returns, low risk. J. Mark. 2006, 70, 3-14. [CrossRef]

160. Carroll, A.B. A three-dimensional conceptual model of corporate performance. Acad. Manag. Rev. 1979, 4, 497-505.

161. Turker, D. How Corporate Social Responsibility Influences Organizational Commitment. J. Bus. Ethics 2009, 89, 189-204. [CrossRef]

162. Pérez, A.; Martínez, P.; Rodríguez, D.B.I. The development of a stakeholder-based scale for measuring corporate social responsibility in the banking industry. Serv. Bus. 2013, 7, 459-481. [CrossRef]

163. Reverte, C.; Gómez-Melero, E.; Cegarra-Navarro, J.G. The influence of corporate social responsibility practices on organizational performance: Evidence from Eco-Responsible Spanish firms. J. Clean. Prod. 2016, 112 Pt 4, 2870-2884. [CrossRef]

164. Ağan, Y.; Kuzey, C.; Acar, M.F.; Açıkgöz, A. The relationships between corporate social responsibility, environmental supplier development, and firm performance. J. Clean. Prod. 2016, 112 Pt 3, 1872-1881. [CrossRef]

165. Kang, J.-S.; Chiang, C.-F.; Huangthanapan, K.; Downing, S. Corporate social responsibility and sustainability balanced scorecard: The case study of family-owned hotels. Int. J. Hosp. Manag. 2015, 48, 124-134. [CrossRef]

166. Zhu, Q.; Liu, J.; Lai, K. Corporate social responsibility practices and performance improvement among Chinese national state-owned enterprises. Int. J. Prod. Econ. 2016, 171 Pt 3, 417-426. [CrossRef]

167. Gallardo-Vázquez, D.; Sanchez-Hernandez, M.I. Measuring Corporate Social Responsibility for competitive success at a regional level. J. Clean. Prod. 2014, 72, 14-22. [CrossRef]

168. Zhu, Q.; Zhang, Q. Evaluating practices and drivers of corporate social responsibility: The Chinese context. J. Clean. Prod. 2015, 100, 315-324. [CrossRef]

169. Laguir, I.; Staglianò, R.; Elbaz, J. Does corporate social responsibility affect corporate tax aggressiveness? J. Clean. Prod. 2015, 107, 662-675. [CrossRef]

170. González-Rodríguez, M.R.; Díaz-Fernández, M.C.; Simonetti, B. The social, economic and environmental dimensions of corporate social responsibility: The role played by consumers and potential entrepreneurs. Int. Bus. Rev. 2015, 24, 836-848. [CrossRef]

171. Peterson, G.D.; Cumming, G.S.; Carpenter, S.R. Scenario planning: A tool for conservation in an uncertain world. Conserv. Biol. 2003, 17, 358-366. [CrossRef]

172. Kowalski, K.; Stagl, S.; Madlener, R.; Omann, I. Sustainable energy futures: Methodological challenges in combining scenarios and participatory multi-criteria analysis. Eur. J. Oper. Res. 2009, 197, 1063-1074. [CrossRef]

173. Seetharaman, A.; Sandanaraj, L.L.; Moorthy, M.K.; Saravanan, A.S. Enterprise framework for renewable energy. Renew. Sustain. Energy Rev. 2016, 54, 1368-1381. [CrossRef]

174. Böttcher, C.; Müller, M. Insights on the impact of energy management systems on carbon and corporate performance. An empirical analysis with data from German automotive suppliers. J. Clean. Prod. 2016, 137, 1449-1457. [CrossRef]

175. Huang, S.-C.; Lo, S.-L.; Lin, Y.-C. Application of a fuzzy cognitive map based on a structural equation model for the identification of limitations to the development of wind power. Energy Policy 2013, 63, 851-861. [CrossRef]

176. Chou, J.-S.; Kim, C.; Ung, T.-K.; Yutami, I.G.A.N.; Lin, G.-T.; Son, H. Cross-country review of smart grid adoption in residential buildings. Renew. Sustain. Energy Rev. 2015, 48, 192-213. [CrossRef]

177. Böttcher, C.F.; Müller, M. Drivers, Practices and Outcomes of Low-carbon Operations: Approaches of German Automotive Suppliers to Cutting Carbon Emissions. Bus. Strategy Environ. 2015, 24, 477-498. [CrossRef]

178. Khorasanizadeh, H.; Honarpour, A.; Park, M.S.-A.; Parkkinen, J.; Parthiban, R. Adoption factors of cleaner production technology in a developing country: Energy efficient lighting in Malaysia. J. Clean. Prod. 2016, 131, 97-106. [CrossRef]

179. Lin, C.-Y.; Syrgabayeva, D. Mechanism of environmental concern on intention to pay more for renewable energy: Application to a developing country. Asia Pac. Manag. Rev. 2016, 21, 125-134. [CrossRef]

180. Chen, Y.-S.; Lai, S.-B.; Wen, C.-T. The influence of green innovation performance on corporate advantage in Taiwan. J.Bus. Ethics 2006, 67, 331-339. [CrossRef] 
181. Govindan, K.; Soleimani, H. A review of reverse logistics and closed-loop supply chains: A Journal of Cleaner Production focus. J. Clean. Prod. 2017, 142, 371-384. [CrossRef]

182. Reid, A.; Miedzinski, M. Eco-Innovation: Final Report for Sectoral Innovation Watch; Systematic Eco-Innovation Report; Europe Innova: Brussels, Belgium, 2008.

183. Zailani, S.; Govindan, K.; Iranmanesh, M.; Shaharudin, M.R.; Sia Chong, Y. Green innovation adoption in automotive supply chain: The Malaysian case. J. Clean. Prod. 2015, 108 Pt A, 1115-1122. [CrossRef]

184. Zhu, Q.; Sarkis, J. Relationships between operational practices and performance among early adopters of green supply chain management practices in Chinese manufacturing enterprises. J. Oper. Manag. 2004, 22, 265-289. [CrossRef]

185. Eltayeb, T.K.; Zailani, S.; Ramayah, T. Green supply chain initiatives among certified companies in Malaysia and environmental sustainability: Investigating the outcomes. Resour. Conserv. Recycl. 2011, 55, 495-506. [CrossRef]

186. Chen, Y.-S. The driver of green innovation and green image-Green core competence. J. Bus. Ethics 2008, 81, 531-543. [CrossRef]

187. Porter, M.E.; van der Linde, C. Green and competitive: Ending the stalemate. Harv. Bus. Rev. 2000, 73, 120-134.

188. Zhu, Q.; Sarkis, J.; Lai, K. Green supply chain management implications for "closing the loop". Transp. Res. Part E Logist. Transp. Rev. 2008, 44, 1-18. [CrossRef]

189. Albort-Morant, G.; Leal-Millán, A.; Cepeda-Carrión, G. The antecedents of green innovation performance: A model of learning and capabilities. J. Bus. Res. 2016, 69, 4912-4917. [CrossRef]

190. Chen, Y.S.; Chang, C.H.; Wu, F.S. Origins of green innovations: The differences between proactive and reactive green innovations. Manag. Decis. 2012, 50, 368-398. [CrossRef]

191. Chan, H.K.; Yee, R.W.Y.; Dai, J.; Lim, M.K. The moderating effect of environmental dynamism on green product innovation and performance. Int. J. Prod. Econ. 2016, 181 Pt B, 384-391. [CrossRef]

192. Segarra-Oña, M.; Peiró-Signes, Á.; Mondéjar-Jiménez, J. Twisting the twist: How manufacturing \& knowledge-intensive firms excel over manufacturing \& operational and all service sectors in their eco-innovative orientation. J. Clean. Prod. 2016, 138 Pt 1, 19-27.

193. Kam-Sing Wong, S. The influence of green product competitiveness on the success of green product innovation: Empirical evidence from the Chinese electrical and electronics industry. Eur. J. Innov. Manag. 2012, 15, 468-490. [CrossRef]

194. Abdullah, M.; Zailani, S.; Iranmanesh, M.; Jayaraman, K. Barriers to green innovation initiatives among manufacturers: The Malaysian case. Rev. Manag. Sci. 2016, 10, 683-709. [CrossRef]

195. Segarra-Oña, M.; Peiró-Signes, A.; Payá-Martínez, A. Factors Influencing Automobile Firms' Eco-Innovation Orientation. Eng. Manag. J. 2014, 26, 31-38. [CrossRef]

196. Chen, P.-C.; Hung, S.-W. Collaborative green innovation in emerging countries: A social capital perspective. Int. J. Oper. Prod. Manag. 2014, 34, 347-363. [CrossRef]

197. Lin, R.-J.; Chen, R.-H.; Huang, F.-H. Green innovation in the automobile industry. Ind. Manag. Data Syst. 2014, 114, 886-903. [CrossRef]

198. Pedersen, E.R.G.; Gwozdz, W.; Hvass, K.K. Exploring the Relationship Between Business Model Innovation, Corporate Sustainability, and Organisational Valueswithin the Fashion Industry. J. Bus. Ethics 2016. [CrossRef]

199. Epstein, M.J.; Buhovac, A.R. Making Sustainability Work: Best Practices in Managing and Measuring Corporate Social, Environmental, and Economic Impacts; Berrett-Koehler Publishers, Inc.: San Francisco, CA, USA, 2014.

200. Ehnert, I. Sustainable Human Resource Management. A Conceptual and Exploratory Analysis from a Paradox Perspective; Springer: Heidelberg, Germany, 2009.

201. Kramar, R. Beyond strategic human resource management: Is sustainable human resource management the next approach? Int. J. Hum. Resour. Manag. 2014, 25, 1069-1089. [CrossRef]

202. Bach, S. Human Resource Management in Transition. In Managing Human Resources: Human Resource Management in Transition; Bach, S., Edwards, M.R., Eds.; John Wiley \& Sons, Inc.: Hoboken, NJ, USA, 2009. [CrossRef]

203. Renwick, D.W.S.; Redman, T.; Maguire, S. Green Human Resource Management: A Review and Research Agenda. Int. J. Manag. Rev. 2013, 15, 1-14. [CrossRef] 
204. Kalamas, M.; Cleveland, M.; Laroche, M. Pro-environmental behaviors for thee but not for me: Green giants, green Gods, and external environmental locus of control. J. Bus. Res. 2014, 67, 12-22. [CrossRef]

205. Zhan, Y.; Tan, K.H.; Ji, G.; Chung, L.; Chiu, A.S.F. Green and lean sustainable development path in China: Guanxi, practices and performance. Resour. Conserv. Recycl. 2016, in press. [CrossRef]

206. Wan, C.; Shen, G.Q. Encouraging the use of urban green space: The mediating role of attitude, perceived usefulness and perceived behavioural control. Habitat Int. 2015, 50, 130-139. [CrossRef]

207. Wan, C.; Shen, G.Q.; Yu, A. The role of perceived effectiveness of policy measures in predicting recycling behaviour in Hong Kong. Resour. Conserv. Recycl. 2014, 83, 141-151. [CrossRef]

208. Wan, C.; Shen, G.Q.; Yu, A. The moderating effect of perceived policy effectiveness on recycling intention. J. Environ. Psychol. 2014, 37, 55-60. [CrossRef]

209. Chin, H.-C.; Choong, W.-W.; Alwi, S.R.W.; Mohammed, A.H. Using Theory of Planned Behaviour to explore oil palm smallholder planters' intention to supply oil palm residues. J. Clean. Prod. 2016, 126, 428-439. [CrossRef]

210. Chiu, Y.-T.H.; Lee, W.-I.; Chen, T.-H. Environmentally responsible behavior in ecotourism: Antecedents and implications. Tour. Manag. 2014, 40, 321-329. [CrossRef]

211. Zhang, B.; Wang, Z.; Lai, K. Mediating effect of managers' environmental concern: Bridge between external pressures and firms' practices of energy conservation in China. J. Environ. Psychol. 2015, 43, 203-215. [CrossRef]

212. Ramayah, T.; Lee, J.W.C.; Lim, S. Sustaining the environment through recycling: An empirical study. J. Environ. Manag. 2012, 102, 141-147. [CrossRef] [PubMed]

213. Zareie, B.; Jafari Navimipour, N. The impact of electronic environmental knowledge on the environmental behaviors of people. Comput. Hum. Behav. 2016, 59, 1-8. [CrossRef]

214. Jiménez-Parra, B.; Rubio, S.; Vicente-Molina, M.-A. Key drivers in the behavior of potential consumers of remanufactured products: A study on laptops in Spain. J. Clean. Prod. 2014, 85, 488-496. [CrossRef]

215. Larrán Jorge, M.; Herrera Madueño, J.; Martínez-Martínez, D.; Lechuga Sancho, M.P. Competitiveness and environmental performance in Spanish small and medium enterprises: Is there a direct link? J. Clean. Prod. 2015, 101, 26-37. [CrossRef]

216. Yusof, N.A.; Zainul Abidin, N.; Zailani, S.H.M.; Govindan, K.; Iranmanesh, M. Linking the environmental practice of construction firms and the environmental behaviour of practitioners in construction projects. J. Clean. Prod. 2016, 121, 64-71. [CrossRef]

217. Wang, J.; Wu, L. The impact of emotions on the intention of sustainable consumption choices: Evidence from a big city in an emerging country. J. Clean. Prod. 2016, 126, 325-336. [CrossRef]

218. Carmona-Moreno, E.; Céspedes-Lorente, J.; Martinez-del-Rio, J. Environmental human resource management and competitive advantage. Manag. Res. J. Iberoam. Acad. Manag. 2012, 10, 125-142. [CrossRef]

219. Wan, C.; Cheung, R.; Qiping Shen, G. Recycling attitude and behaviour in university campus: A case study in Hong Kong. Facilities 2012, 30, 630-646. [CrossRef]

220. Tien-Shang Lee, L. The pivotal roles of corporate environment responsibility. Ind. Manag. Data Syst. 2012, 112, 466-483. [CrossRef]

221. Kim, M.J.; Lee, C.K.; Gon Kim, W.; Kim, J.M. Relationships between lifestyle of health and sustainability and healthy food choices for seniors. Int. J. Contemp. Hosp. Manag. 2013, 25, 558-576. [CrossRef]

222. Paillé, P.; Chen, Y.; Boiral, O.; Jin, J. The Impact of Human Resource Management on Environmental Performance: An Employee-Level Study. J. Bus. Ethics 2014, 121, 451-466. [CrossRef]

223. Ahmad, M.S.; Bazmi, A.A.; Bhutto, A.W.; Shahzadi, K.; Bukhari, N. Students' Responses to Improve Environmental Sustainability through Recycling: Quantitatively Improving Qualitative Model. Appl. Res. Qual. Life 2016, 11, 253-270. [CrossRef]

224. Dögl, C.; Holtbrügge, D. Corporate environmental responsibility, employer reputation and employee commitment: An empirical study in developed and emerging economies. Int. J. Hum. Resour. Manag. 2014, 25, 1739-1762. [CrossRef]

225. Cegarra-Navarro, J.G.; Cordoba-Pachon, J.-R.; Fernandez de Bobadilla, G.W. Creating environmental knowledge through 'green communities' in the Spanish pharmaceutical industry. Serv. Ind. J. 2009, 29, 1745-1761. [CrossRef] 
226. Kim, H.J.; Park, J.; Wen, J. General managers' environmental commitment and environmental involvement of lodging companies: The mediating role of environmental management capabilities. Int. J. Contemp. Hosp. Manag. 2015, 27, 1499-1519. [CrossRef]

227. Castellanos-Verdugo, M.; Vega-Vázquez, M.; Oviedo-García, M.Á.; Orgaz-Agüera, F. The relevance of psychological factors in the ecotourist experience satisfaction through ecotourist site perceived value. J. Clean. Prod. 2016, 124, 226-235. [CrossRef]

228. Gonul Kochan, C.; Pourreza, S.; Tran, H.; Prybutok, V.R. Determinants and logistics of e-waste recycling. Int. J. Logist. Manag. 2016, 27, 52-70. [CrossRef]

229. Kura, K.M. Linking Environmentally Specific Transformational Leadership and Environmental Concern to Green Behaviour at Work. Glob. Bus. Rev. 2016, 17, 1S-14S. [CrossRef]

230. Ulubeyli, S. Drivers of environmental performance of cement plants. Ind. Manag. Data Syst. 2013, 113, 1222-1244. [CrossRef]

231. Llach, J.; Alonso-Almeida, M.D.M.; García-Castellví, A.; Bagur-Femenias, L. A fresh approach to context influence, development and performance in environmental management. Bus. Strategy Environ. 2015, 24, 855-872. [CrossRef]

232. Thieme, J.; Royne, M.B.; Jha, S.; Levy, M.; Barnes McEntee, W. Factors affecting the relationship between environmental concern and behaviors. Mark. Intell. Plan. 2015, 33, 675-690. [CrossRef]

233. Iniesta-Bonillo, M.A.; Sánchez-Fernández, R.; Jiménez-Castillo, D. Sustainability, value, and satisfaction: Model testing and cross-validation in tourist destinations. J. Bus. Res. 2016, 69, 5002-5007. [CrossRef]

234. Castaneda, M.G.; Martinez, C.P.; Marte, R.; Roxas, B. Explaining the environmentally-sustainable consumer behavior: A social capital perspective. Soc. Responsib. J. 2015, 11, 658-676. [CrossRef]

235. Guerci, M.; Longoni, A.; Luzzini, D. Translating stakeholder pressures into environmental performance-The mediating role of green HRM practices. Int. J. Hum. Resour. Manag. 2016, 27, 262-289. [CrossRef]

236. Bowker, G.C. Biodiversity datadiversity. Soc.Stud. Sci. 2000, 30, 643-683. [CrossRef]

237. Fortun, K. Environmental information systems as appropriate technology. Des. Issues 2004, $20,54-65$. [CrossRef]

238. Meadowcroft, J. Who is in charge here? Governance for sustainable development in a complex world. J. Environ. Policy Plan. 2007, 9, 299-314. [CrossRef]

239. Melville, N.P. Information systems innovation for environmental sustainability. MIS Q. 2010, 34, 1-21.

240. Jankowski, P. Towards participatory geographic information systems for community-based environmental decision making. J. Environ. Manag. 2009, 90, 1966-1971. [CrossRef] [PubMed]

241. Prévost, Y.; Gilruth, P. Environmental Information Systems in Sub-Saharan Africa: From Innovation to Management. In Africa Region Findings \& Good Practice Infobriefs; License: CC BY 3. 0 IGO, No. 128; World Bank: Washington, DC, USA, 1999; Available online: https:/ / openknowledge.worldbank.org/handle/10986/9874 (accessed on 9 october 2017).

242. Gholami, R.; Sulaiman, A.B.; Ramayah, T.; Molla, A. Senior managers' perception on green information systems (IS) adoption and environmental performance: Results from a field survey. Inf. Manag. 2013, 50, 431-438. [CrossRef]

243. Ryoo, S.Y.; Koo, C. Green practices-IS alignment and environmental performance: The mediating effects of coordination. Inf. Syst. Front. 2013, 15, 799-814. [CrossRef]

244. Akman, I.; Mishra, A. Sector diversity in Green Information Technology practices: Technology Acceptance Model perspective. Comput. Hum. Behav. 2015, 49, 477-486. [CrossRef]

245. Schniederjans, D.G.; Hales, D.N. Cloud computing and its impact on economic and environmental performance: A transaction cost economics perspective. Decis. Support Syst. 2016, 86, 73-82. [CrossRef]

246. Koo, C.; Chung, N.; Nam, K. Assessing the impact of intrinsic and extrinsic motivators on smart green IT device use: Reference group perspectives. Int. J. Inf. Manag. 2015, 35, 64-79. [CrossRef]

247. Wang, Y.; Chen, Y.; Benitez-Amado, J. How information technology influences environmental performance: Empirical evidence from China. Int. J. Inf. Manag. 2015, 35, 160-170. [CrossRef]

248. Meacham, J.; Toms, L.; Green, K.W.; Bhadauria, V.S. Impact of information sharing and green information systems. Manag. Res. Rev. 2013, 36, 478-494. [CrossRef]

249. Molla, A.; Abareshi, A. Organizational Green Motivations for Information Technology: Empirical Study. J. Comput. Inf. Syst. 2012, 52, 92-102. 
250. Martínez-Jurado, P.J.; Moyano-Fuentes, J. Lean management, supply chain management and sustainability: A literature review. J. Clean. Prod. 2014, 85, 134-150. [CrossRef]

251. Kelly, A. The three phases of local government state of environment reports in NSW Australia: Complexity, intricacy and creativity. J. Econ. Soc. Policy 2011, 14, 2.

252. Bocken, N.M.P.; Short, S.W.; Rana, P.; Evans, S. A literature and practice review to develop sustainable business model archetypes. J. Clean. Prod. 2014, 65, 42-56. [CrossRef]

253. Lueg, R.; Pedersen, M.M.; Clemmensen, S.N. The role of corporate sustainability in a low-cost business model-A case study in the Scandinavian fashion industry. Bus. Strategy Environ. 2015, 24, 344-359. [CrossRef]

254. Boons, F.; Lüdeke-Freund, F. Business models for sustainable innovation: State-of-the-art and steps towards a research agenda. J. Clean. Prod. 2013, 45, 9-19. [CrossRef]

255. Schaltegger, S.; Lüdeke-Freund, F.; Hansen, E.G. Business cases for sustainability: The role of business model innovation for corporate sustainability. Int. J. Innov. Sustain. Dev. 2012, 6, 95-119. [CrossRef]

256. Jabbour, C.J.C.; Jugend, D.; Jabbour, A.B.L.D.S.; Gunasekaran, A.; Latan, H. Green product development and performance of Brazilian firms: Measuring the role of human and technical aspects. J. Clean. Prod. 2015, 87, 442-451. [CrossRef]

257. Blome, C.; Hollos, D.; Paulraj, A. Green procurement and green supplier development: Antecedents and effects on supplier performance. Int. J. Prod. Res. 2014, 52, 32-49. [CrossRef]

258. Lirn, T.-C.; Lin, H.-W.; Shang, K.-C. Green shipping management capability and firm performance in the container shipping industry. Marit. Policy Manag. 2014, 41, 159-175. [CrossRef]

259. Felix, R.; Braunsberger, K. I believe therefore I care: The relationship between religiosity, environmental attitudes, and green product purchase in Mexico. Int. Mark. Rev. 2016, 33, 137-155. [CrossRef]

260. Stolz, J.; Bautista, R. Corporate sustainability: Perception and response by older consumers. Int. J. Consum. Stud. 2015, 39, 343-351. [CrossRef]

261. Campón-Cerro, A.M.; Hernández-Mogollón, J.M.; Alves, H. Sustainable improvement of competitiveness in rural tourism destinations: The quest for tourist loyalty in Spain. J. Destin. Mark. Manag. 2017, 6, 252-266. [CrossRef]

262. Blohmke, J.; Kemp, R.; Türkeli, S. Disentangling the causal structure behind environmental regulation. Technol. Forecast. Soc. Chang. 2016, 103, 174-190. [CrossRef]

263. Lai, C.K.M.; Cheng, E.W.L. Green purchase behavior of undergraduate students in Hong Kong. Soc. Sci. J. 2016, 53, 67-76. [CrossRef]

264. Luzzini, D.; Brandon-Jones, E.; Brandon-Jones, A.; Spina, G. From sustainability commitment to performance: The role of intra- and inter-firm collaborative capabilities in the upstream supply chain. Int. J. Prod. Econ. 2015, 165, 51-63. [CrossRef]

265. Sheu, J.-B. Power shifts and relationship quality improvement of producer-retailer green channel dyads under government intervention. Ind. Mark. Manag. 2015, 50, 97-116. [CrossRef]

266. Gelhard, C.; von Delft, S. The role of organizational capabilities in achieving superior sustainability performance. J. Bus. Res. 2016, 69, 4632-4642. [CrossRef]

267. Fraj, E.; Matute, J.; Melero, I. Environmental strategies and organizational competitiveness in the hotel industry: The role of learning and innovation as determinants of environmental success. Tour. Manag. 2015, 46, 30-42. [CrossRef]

268. Prud'homme, B.; Raymond, L. Sustainable development practices in the hospitality industry: An empirical study of their impact on customer satisfaction and intentions. Int. J. Hosp. Manag. 2013, 34, 116-126. [CrossRef]

269. Jabbour, A.B.; Jabbour, C.; Govindan, K.; Kannan, D.; Arantes, A.F. Mixed methodology to analyze the relationship between maturity of environmental management and the adoption of green supply chain management in Brazil. Resour. Conserv. Recycl. 2014, 92, 255-267. [CrossRef]

270. Murovec, N.; Erker, R.S.; Prodan, I. Determinants of environmental investments: Testing the structural model. J. Clean. Prod. 2012, 37, 265-277. [CrossRef]

271. Maniatis, P. Investigating factors influencing consumer decision-making while choosing green products. J. Clean. Prod. 2016, 132, 215-228. [CrossRef]

272. Reuter, C.; Goebel, P.; Foerstl, K. The impact of stakeholder orientation on sustainability and cost prevalence in supplier selection decisions. J. Purch. Supply Manag. 2012, 18, 270-281. [CrossRef] 
273. Chekima, B.; Chekima, S.; Syed Khalid Wafa, S.A.W.; Igau, O.A.; Sondoh, S.L. Sustainable consumption: The effects of knowledge, cultural values, environmental advertising, and demographics. Int. J. Sustain. Dev. World Ecol. 2016, 23, 210-220. [CrossRef]

274. Hanim Mohamad Zailani, S.; Eltayeb, T.K.; Hsu, C.C.; Choon Tan, K. The impact of external institutional drivers and internal strategy on environmental performance. Int. J. Oper. Prod. Manag. 2012, 32, 721-745. [CrossRef]

275. Hong, P.; Kwon, H.B.; Roh, J.J. Implementation of strategic green orientation in supply chain: An empirical study of manufacturing firms. Eur. J. Innov. Manag. 2009, 12, 512-532. [CrossRef]

276. Chen, Y.-S.; Chang, C.-H. Enhance environmental commitments and green intangible assets toward green competitive advantages: An analysis of structural equation modeling (SEM). Qual. Quant. 2013, 47, 529-543. [CrossRef]

277. Clark, J.W.; Toms, L.C.; Green, K.W. Market-oriented sustainability: Moderating impact of stakeholder involvement. Ind. Manag. Data Syst. 2014, 114, 21-36. [CrossRef]

278. Green, K.W.; Toms, L.C.; Clark, J. Impact of market orientation on environmental sustainability strategy. Manag. Res. Rev. 2015, 38, 217-238. [CrossRef]

279. Tirado-Valencia, P.; Rodero-Cosano, M.L.; Ruiz-Lozano, M.; Rios-Berjillos, A. Online sustainability information in European local governments: An explicative model to improve transparency. Online Inf. Rev. 2016, 40, 400-415. [CrossRef]

280. Li, S.; Jayaraman, V.; Paulraj, A.; Shang, K. Proactive environmental strategies and performance: Role of green supply chain processes and green product design in the Chinese high-tech industry. Int. J. Prod. Res. 2016, 54, 2136-2151. [CrossRef]

281. Li, E.L.; Zhou, L.; Wu, A. The supply-side of environmental sustainability and export performance: The role of knowledge integration and international buyer involvement. Int. Bus. Rev. 2017, 26, 724-735. [CrossRef]

282. Chen, S.-C.; Hung, C.-W. Elucidating the factors influencing the acceptance of green products: An extension of theory of planned behavior. Technol. Forecast. Soc. Chang. 2016, 112, 155-163. [CrossRef]

283. Yusof, N.A.; Rahman, S.; Iranmanesh, M. The environmental practice of resorts and tourist loyalty: The role of environmental knowledge, concern, and behaviour. Anatolia 2016, 27, 214-226. [CrossRef]

284. Leonidou, C.N.; Katsikeas, C.S.; Morgan, N.A. "Greening” the marketing mix: Do firms do it and does it pay off? J. Acad. Mark. Sci. 2013, 41, 151-170. [CrossRef]

285. Kumar, P.K.; Anand, B. Green Marketing: Theory, Practice, and Strategies. Indian J. Mark. 2013, 43, 54-56. [CrossRef]

286. Ottman, J.A. Green Marketing: Challenges and Opportunities for the New Marketing Age; NTC Business Books: Lincolnwood, IL, USA, 1993.

287. Prakash, A. Green marketing, public policy and managerial strategies. Bus. Strategy Environ. 2002, 11, 285-297. [CrossRef]

288. Peattie, K. Environmental Marketing Management: Meeting the Green Challenge; Financial Times Management: London, UK, 1995.

289. Pickett-Baker, J.; Ozaki, R. Pro-environmental products: Marketing influence on consumer purchase decision. J. Consum. Mark. 2008, 25, 281-293. [CrossRef]

290. De Giovanni, P.; Esposito Vinzi, V. The benefits of a monitoring strategy for firms subject to the Emissions Trading System. Transp. Res. Part D Transp. Environ. 2014, 33, 220-233. [CrossRef]

291. Martínez-Martínez, A.; Cegarra-Navarro, J.-G.; García-Pérez, A. Environmental knowledge management: A long-term enabler of tourism development. Tour. Manag. 2015, 50, 281-291. [CrossRef]

292. Jabbour, C.J.C.; Jabbour, A.B.L.D.S.; Govindan, K.; Teixeira, A.A.; Freitas, W.R.D.S. Environmental management and operational performance in automotive companies in Brazil: The role of human resource management and lean manufacturing. J. Clean. Prod. 2013, 47, 129-140. [CrossRef]

293. Xia, D.; Chen, B.; Zheng, Z. Relationships among circumstance pressure, green technology selection and firm performance. J. Clean. Prod. 2015, 106, 487-496. [CrossRef]

294. Wu, S.J.; Melnyk, S.A.; Calantone, R.J. Assessing the core resources in the environmental management system from the resource perspective and the contingency perspective. IEEE Trans. Eng. Manag. 2008, 55, 304-315. [CrossRef]

295. Yu, W.; Ramanathan, R. An empirical examination of stakeholder pressures, green operations practices and environmental performance. Int. J. Prod. Res. 2015, 53, 6390-6407. [CrossRef] 
296. Jabbour, C.J.C. Environmental training and environmental management maturity of Brazilian companies with ISO14001: Empirical evidence. J. Clean. Prod. 2015, 96, 331-338. [CrossRef]

297. Molina-Azorín, J.F.; Tarí, J.J.; Pereira-Moliner, J.; López-Gamero, M.D.; Pertusa-Ortega, E.M. The effects of quality and environmental management on competitive advantage: A mixed methods study in the hotel industry. Tour. Manag. 2015, 50, 41-54. [CrossRef]

298. Gotschol, A.; De Giovanni, P.; Esposito Vinzi, V. Is environmental management an economically sustainable business? J. Environ. Manag. 2014, 144, 73-82. [CrossRef] [PubMed]

299. Hajmohammad, S.; Vachon, S.; Klassen, R.D.; Gavronski, I. Lean management and supply management: Their role in green practices and performance. J. Clean. Prod. 2013, 39, 312-320. [CrossRef]

300. Sen, P.; Roy, M.; Pal, P. Exploring role of environmental proactivity in financial performance of manufacturing enterprises: A structural modelling approach. J. Clean. Prod. 2015, 108 Pt A, 583-594. [CrossRef]

301. Hwang, G.H.; Jeong, S.K.; Ban, Y.U. Causal relationship of eco-industrial park development factors: A structural equation analysis. J. Clean. Prod. 2016, 114, 180-188. [CrossRef]

302. Pondeville, S.; Swaen, V.; De Rongé, Y. Environmental management control systems: The role of contextual and strategic factors. Manag. Account. Res. 2013, 24, 317-332. [CrossRef]

303. Thirupathi, R.M.; Vinodh, S. Application of interpretive structural modelling and structural equation modelling for analysis of sustainable manufacturing factors in Indian automotive component sector. Int. J. Prod. Res. 2016, 54, 6661-6682. [CrossRef]

304. Aras, G.; Crowther, D. Making sustainable development sustainable. Manag. Decis. 2009, 47, 975-988. [CrossRef]

305. Bagur-Femenias, L.; Llach, J.; del Mar Alonso-Almeida, M. Is the adoption of environmental practices a strategical decision for small service companies? Manag. Decis. 2013, 51, 41-62. [CrossRef]

306. De Giovanni, P. Do internal and external environmental management contribute to the triple bottom line? Int. J. Oper. Prod. Manag. 2012, 32, 265-290. [CrossRef]

307. Kim, S.T.; Lee, S.Y. Stakeholder pressure and the adoption of environmental logistics practices: Is eco-oriented culture a missing link? Int. J. Logist. Manag. 2012, 23, 238-258. [CrossRef]

308. Wiengarten, F.; Fynes, B.; Onofrei, G. Exploring synergetic effects between investments in environmental and quality/lean practices in supply chains. Supply Chain Manag. Int. J. 2013, 18, 148-160. [CrossRef]

309. Vinodh, S.; Joy, D. Structural equation modeling of sustainable manufacturing practices. Clean Technol. Environ. Policy 2012, 14, 79-84. [CrossRef]

310. Hajmohammad, S.; Vachon, S. Safety Culture: A Catalyst for Sustainable Development. J. Bus. Ethic 2014, 123, 263-281. [CrossRef]

311. Benitez-Amado, J.; Llorens-Montes, F.J.; Fernandez-Perez, V. IT impact on talent management and operational environmental sustainability. Inf. Technol. Manag. 2015, 16, 207-220. [CrossRef]

312. Freise, M.; Seuring, S. Social and environmental risk management in supply chains: A survey in the clothing industry. Logist. Res. 2015, 8, 2. [CrossRef]

313. Jabbour, C.J.C.; de Sousa Jabbour, A.B.L.; Govindan, K.; de Freitas, T.P.; Soubihia, D.F.; Kannan, D.; Latan, H. Barriers to the adoption of green operational practices at Brazilian companies: Effects on green and operational performance. Int. J. Prod. Res. 2016, 54, 3042-3058. [CrossRef]

314. Koo, C.; Chung, N.; Ryoo, S.Y. How does ecological responsibility affect manufacturing firms' environmental and economic performance? Total Qual. Manag. Bus. Excell. 2014, 25, 1171-1189. [CrossRef]

315. Kuei, C.; Chow, W.S.; Madu, C.N.; Wu, J.P. Identifying critical enablers to high performance environmental management: An empirical study of Chinese firms. J. Environ. Plan. Manag. 2013, 56, 1152-1179. [CrossRef]

316. Yu, W.; Ramanathan, R. Environmental management practices and environmental performance: The roles of operations and marketing capabilities. Ind. Manag. Data Syst. 2016, 116, 1201-1222. [CrossRef]

317. Hair, J.F., Jr.; Hult, G.T.M.; Ringle, C.; Sarstedt, M. A Primer on Partial Least Squares Structural Equation Modeling (PLS-SEM); Sage Publications Inc.: Thousand Oaks, CA, USA, 2016.

318. Kline, R.B. Principles and Practice of Structural Equation Modeling; Guilford Publications: New York, NY, USA, 2015.

319. Bryman, A.; Bell, E. Business Research Methods; Oxford University Press: Oxford, UK, 2015.

320. Zikmund, W.G.; Babin, B.J.; Carr, J.C.; Griffin, M. Business Research Methods; Cengage Learning EMEA: Hampshire, UK, 2013. 
321. Zumbo, B.D.; Chan, E.K. Validity and Validation in Social, Behavioral, and Health Sciences; Social Indicators Research Series 54; Springer International Publishing: Cham, Switzerland, 2014.

322. Ajzen, I.; Fishbein, M. A Bayesian analysis of attribution processes. Psychol. Bull. 1975, 82, 261. [CrossRef]

323. Hsu, M.-H.; Yen, C.-H.; Chiu, C.-M.; Chang, C.-M. A longitudinal investigation of continued online shopping behavior: An extension of the theory of planned behavior. Int. J. Hum. Comput. Stud. 2006, 64, 889-904. [CrossRef]

324. Pavlou, P.A.; Fygenson, M. Understanding and predicting electronic commerce adoption: An extension of the theory of planned behavior. MIS Q. 2006, 30, 115-143.

(C) 2017 by the authors. Licensee MDPI, Basel, Switzerland. This article is an open access article distributed under the terms and conditions of the Creative Commons Attribution (CC BY) license (http:/ / creativecommons.org/licenses/by/4.0/). 